University of Louisville

ThinkIR: The University of Louisville's Institutional Repository

Electronic Theses and Dissertations

1949

\title{
The structure of Whitman's Song of myself.
}

Jane Kinney Hill

University of Louisville

Follow this and additional works at: https://ir.library.louisville.edu/etd

Part of the Literature in English, North America Commons

\section{Recommended Citation}

Hill, Jane Kinney, "The structure of Whitman's Song of myself." (1949). Electronic Theses and Dissertations. Paper 1967.

https://doi.org/10.18297/etd/1967

This Master's Thesis is brought to you for free and open access by ThinkIR: The University of Louisville's Institutional Repository. It has been accepted for inclusion in Electronic Theses and Dissertations by an authorized administrator of ThinkIR: The University of Louisville's Institutional Repository. This title appears here courtesy of the author, who has retained all other copyrights. For more information, please contact thinkir@louisville.edu. 
THE STRUCTURE OF' WHITMAN'S "SONG OF MYSELF"

\author{
A Thesis \\ Presented to \\ the faculty of the Department of English \\ University of Louisville
}

In Partial Fulfillment

of the Requirements for the Degree

Master of Arts

by

Jane Kinney $\mathrm{Hill}$

March 1949 
NAME OF STUDENT: JANE KINNEY HILL

TITLE OF THESIS: THE STRUCTURE OF WHITMAN'S "SONG OF WYSELF"

APPROVED BY READING COMHTTE COMPOSED OF THE

FOLLOWING MEMBERS:

Ernest Hassold

NAIE OF DIRECTOR: _ Ernest Hassold

DATE: $\ln y \cot 2748$ 


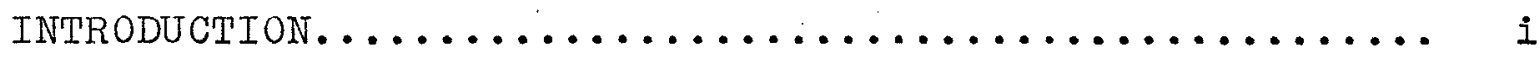

PART $1:$ GENERAI STRUCTURE.................. I

Introduction. ................... I

Detailed study................... 6

The Introduction................... 10

The Prelude...................... 15

The Close...................... 51

Conclusion to Part one................ 56

PART 1l: THE CATALOGUE.................. 58

Introduction...................... 58

The long catalogues...................6 63

Stanzaic and Verse Catalogues.........6 69

First study................... 69

Second study.................. 76

Third study................. 88

Verse Catalogue..................... 94

Conclusion to Part Two.................. 104

PART 111: VERBAL PROGRESSION..................... 106

Illustration A..................... 114

Illustration B.........................

CONCLUSION.............................. 135

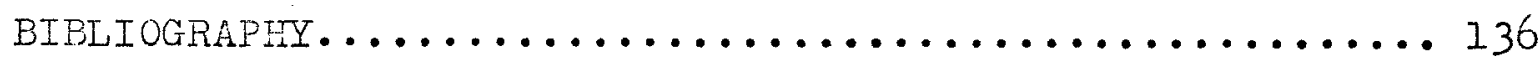




\section{LIST OF CHARTS}

CHART

PAGE

1. The Thought Pattern of the "Song of Iilyself"..... 3

11. Structural Balance of Five seationsuof

Introduction........................ II

111. A Structural Outline of the Progressions........ I9

IV. Balance of Progressions.................... 22

V. A structural Outine of Catalogues and

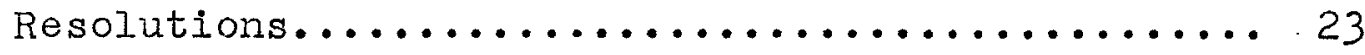

VI. A Structural Outline of the Catalogues.......... 50

V11. Structural Arrangement of the Five Sections

of the Close......................... 52

V111. Structural Balance between the Long Catalogues

of the First and Last Parts of the Poem......... 63

1X. The Place of the Catalogues of Identity-Sense

as Related to the Catalogues of the First and

Last Parts of the Poem.................... 89

X. Structural Pattern of the Verse Catalogue of

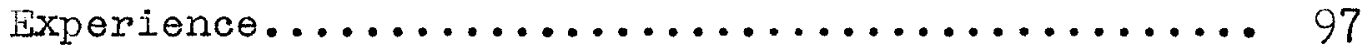

XI. Verbal Progression: Depicting the Four Flights

of Associational Ideas Found in Lines

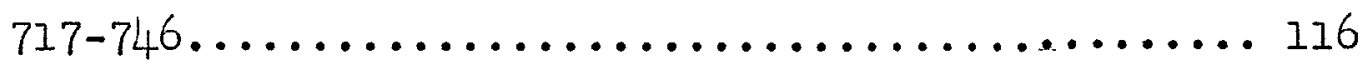

XIl. Verbal Progression: Depicting the Three Flights

of Associated Ideas Found in Iines

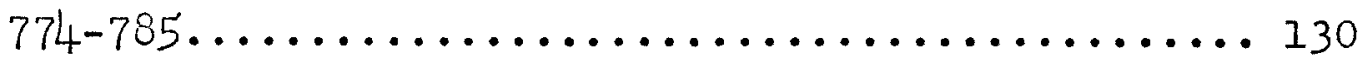


INTRODUCTION 


\section{INTRODUCTION}

Any needed justification for making a study of the structure of the "Song of Myself" resides in a conviction that the treatment accorded Whitman's poetry in general emphasizes form as a single criterion ${ }^{1}$ and, thus, almost completely separates it from the ideas or thoughts the form imparts. All too often the critics have emphasized the form of his poetry rather than the contents or ideas the form conveyed. This tendency to ignore the fact that form has little meaning except as a vehicle for carrying thought ${ }^{2}$ has been especially apparent in criticism of the "Song of liyself." 3 In fact, there has been an almost total failure to recognize that the structural pattern of the poem takes its shape from the ideas it conveys.

In setting up his own theory of poetic art whitman has denied that form can be predetermined or superimposed and has

1 Bliss Perry, Walt Witman, Houghton Mifflin Company, New York, 1906, p. 81. Henry Hazlitt, The Anatomy of Criticism, Simon and Schuster, New York, 1933, p. 253. Henry Seidel Canby, Walt Whitman, an American, Houghton Mifflin Company, $1943, \mathrm{p} .2$. Henry Seidel Canby, Classic Americans, Harcourt, Brace, and Company, New York, 1931, p. 332.

2 Sculley Bradley, "The Fundamental Metrical Principle in Whitman's Poetry," American Literature, January, 1939, $10: 440$.

Ralph Waldo Emerson, "The Poet," Essays, A. L. Burt Company, New York, no date, p. 228.

3 Killis Campbell, "The Evolution of Whitman as an Artist," American Literature, November, 1934, 6:255. 
stressed the theory of natural organic growth. 4 In the 1855 preface to the Leaves of Grass he claims that all perfect poems reveal "...free growth...as unerringly and loosely as lilacs or roses on a bush, and take shapes as compact as the shapes of chestnuts and oranges and melons and pears, and shed the perfume impalpable to form. 15

Again, in 1876, when he tells us that the poet visits and lives in lands apart from the everyday spectacle, he says :

... as I have lived in fresh lands... I have felt to identify...these lands in my recitatives, altogether in my own way. Thus my form has strictly grown from my purports and facts, and is the analogy of them.

In this statement the poet has given us hints of what we are to expect in his architectural motif. First, there is always a plan in mind before starting a poem; second, this plan is ever subjective to the author's imagination. 7 These ideas suggest the possibility that the irnaginative threads

\footnotetext{
4 Walt Whitman, "A Backward Glance O'er Travel'd
} Roads," The Complete Writings of Walt Whitman (in ten volumes). Issued under the editorial supervision of his literary executors, Richard Maurice Bucke, Thomas Harned, and Horace Traubel, G. P. Putnam's Sons, New York and London, 1902. Vol. 3, p. 48 .

5 Walt Witman, Preface to 1855 Leaves of Grass, The Complete Wiritings of Walt Whitman. Vol. $5, \mathrm{p} .166$.

6 Walt Witman, Preface to 1876 Leaves of Grass, The Complete Wiritings of Walt Witman. Vol. 5, p. 203. p. 307 .

7 Henry Seidel Canby, Walt Whitman, an American, 
of the author can be used as a guide to trace out a general structural pattern for the "Song of Myself."

As an approach to the study of the structure of the poem I shall give a brief resume of certain background material which, I feel, has somewhat influenced the direction of the present study. The first of these, a literary parallel to the "Song of Myself"--Samuel Warren's The Lily and the Bee--8 appeared in Ingland in 1851, four years before the advent of the American song. And, like Whitman's verse, the English poem has been called "...a model of rhythmical prose masking as poetry." 9 The poem, written in commemoration of the crystal Palace exhibition in London, 1851, describes a day, a night, and an early morning in the Crystal Palace. That Warren's work had served as an influence for whitman's "Song of Myself" appears almost certain when one considers the many similarities between the two poems. Four of these corresponding qualities will be considered. The first is that of parallel themes: "Song of Myself"

1. Self: I celebrate myself, and sing myself. 10

8 Samuel Warren, The Lily and the Bee, William Bla ckwood and Sons, Edinburgh and London, 185i.

9 Perry, op. cit., p. 92.

10 "Song of Myself," I. I. All references to the "Song of Miyself" are made to volume one of the complete Writings of Walt Whitman, issued under the editorial supervision of his literary executors, Richard Maurice Bucke, Thomas Harned, and Horace Traubel, G. P. Putnam's Sons, New York and London, 1902. The line number of each succeeding reference to the poem will be enclosed in parentheses. 
2. Identification: And what I assume you shall assume, For every atom belonging to me as good belongs to you. (11. 2-3)

3. Creativity or source of being:

I permit to speak at every hazard, Nature without check with original energy. (11. 12-13)

The Lily and the Bee

1. Self: ...Man, in his relations to the earthll

2. Identification: Vian, in his relations to men ( .6 )

3. Creativity or source of being: Man, in his relations to God. (p. 6)

The like themes of the two poems consider: first, Man alone, the self, an individual; second, lian with others, identification wi th the human spectacle; ${ }^{12}$ third, Nian and natural law, source of being, creativity, God.

A second parallelism is found in expression. Notice the kinship in the following lines:

\section{"Song of Myself"}

This is the meal equally set, this the meat for natural hunger,

It is for the wicked just

the same as the righteous.

(11. 372-373)

My sun has his sun and round him obediently wheels,

He joins with his partners a group of superior circuit, And greater sets follow, making specks of the greatest inside them.

(11. 1187-1189)

\section{The Lily and the Bee}

Poor soul...this banquet is not spread for thee. . (p. q)
Glorious Suns, round Suns, each with its train of Planets and satellites, for ever shrouded in the splendour of their respective suns, from the little eyes of man.

$(p \cdot 52)$

11 Warren, op.cit., p. 6. The page number of each succeeding reference to the poem will be enclosed in parentheses. 
"Song of Myself"

A few quadrillions of eras, a few octillions of cubic leagues, do not hazard the span or make it impatient, They are but parts, any thing is but a part.

$$
\text { (11. 11.94-1195) }
$$

What is a man anyhow? (I. 391)

Rise after rise bow the phantoms behind me, Afar down I see the huge first Nothing...

(11. 1152-1153)

Blind loving wrestling touch, sheath'd hooded sharptoothid touch!

Did it make you ache so, leaving me?

(11. 642-643)

I see in them and myself the same old law.

(1. 252)

I tread day and night such roads.

(1. 797)

Here and there with dimes on the eyes walking,

To feed the greed of the belly the brains liberally spooning,

Tickets buying, taking, selling, but into the feast never once going,

Many sweating, ploughing, thrashing, and then the chaff for payment receiving...

(11. 1070-1073)
The Lily and the Bee

Millions beyond millions upon millions of stars--suns-systems peopling infinitude! (p. 59)

What is man...

(p. 69)

-- whither--whither art thou leading --

0 , fearful flight, down! down! to the Past--

...Flight--flight--soulchilling flight--

$$
\begin{aligned}
& \text { On--on--on! } \\
& \text { (pp. 157-158) }
\end{aligned}
$$

- Transporting rapturous visionl 0 , art thou gone, for ever gone?--

(p. 155)

--Dear insectl I would speak with thee!

I feel a sympathy of kin with thee!

(p. 104)

Descending--again I tread the earth--

(p. 102)

Not for Food or Shelter only, nor to Heal, labour thy slaving sons--

See purple and fine linen glistening there,--apparel gorgeous, proudly worn, forgetinuly!

Yonder, sumptious fare, for dainty pampered appetite to fare upon,

Every day.

(p. 170) 
Also, both poets use a like expression in introducing the visions:

"Song of Myself"

(Introduction to catalogue of experience)

Miy ties and ballasts leave me, my elbows rest in sea-gaps,

I skirt sierras, my palms cover continents,

I am afoot wi th my vision.

(11. 714-716)
The Lily and the Bee

(Introduction to catalogue

of intellect)

A unit unperceived, I sink into the living stream againd - Nave, transept, aisles and galleries, pacing untired: insatiate!

(p. 45)

Parallelism or balance of thoughts marks a third point of relationship:

"Song of Mijyself"

I have heard what the talkers were talking, the talk of the beginning and end,

But I do not talk of the beginning and end. (11. 38-39)

Urge and urge and urge, Always the procreant urge of the world. (11. $44-45)$
The Lily and the Bee

The seventy thousand Eoned All gone,

And I, Alone!

--How dread this silence!

The seventy thousand, with bright sunshine, gone,

And I alone--and moonlight all irradiates solemnly.

(p. 123)

Wan from the grave, around one Man upon the Earth--

Man in eternity, around one Man in Time--

(p. 128)

And I know that the hand of God is the promise of my own, And I know that the spirit

All gonel--the living stream, with its mysterious hum--

Ny brethren! and my sisters! of God is the brother of my own.goned From every clime, of (11. 92-93) every hue, and every tongued (p. 124)

Twenty-eight young men bathe by the shore,

Twenty-eight young men and all so friendly.

(11. 199-200)
The fear of death hath fallen upon me--

Fearfulness and trembling are come upon me.

(p. 161) 
The city sleeps and the country sleeps, The living sleep for their time, the dead sleep for their time.

\section{(11. 324-325)}

I have said that the soul is not more than the body, And I have said that the body is not more than the soul.

(11. 1269-1270) Evel

Mother of all living, Adam, Father of all mankind!

(p. 163)

Hope for Hopeless!

Faith for Faithless! (p. 198)

A fourth likeness between the "Song of Myself" and The Iily and the Bee is found in the catalogue. Compare the following representative lists from both poems:

"Song of Myself"

The pure contralto sings

in the organ loft,

The carpenter dresses his plank, the tongue of the foreplane whistles its wild ascending lisp,

The married and unmarried children ride home to their Thanksgiving dinner,

The pilot seizes the kingpin, he heaves down with a strong arm,

The mate stands braced in the whale-boat, lance and harpoon are ready,

The duck shooter walks by silent and cautious stretches, The deacons are ordain'd with cross'd hands at the altar,

The spinning-girl retreats and advances to the hum of the big wheel,

The farmer stops by the bars as he walks on a Firstday loafe...

The lunatic is carried at last to the asylum...
The Lily and the Bee

Here is a voluble smatterer: suddenly discomfited by the chance question of a curious chila...

There a bustling piece of earth: one of the earth, earthy: testing everything by money value.

Here is a stale bundle of prejudices, hard bound together: to whom everything here is topsy-turvy...

Here comes one serenely unconscious that he is a fool.

There is one sudderly startled by a suspicion that he knows scarcely anything.

Here is one listening, with seeming lively interest...to a scientific explanation...

There is one falsely thinking himself the observed of observers...

Here is one that will not see a timid poor relation...

Yonder is a statesman: liding about alone... 
The jour printer with gray head and gaunt jaws works at his case,

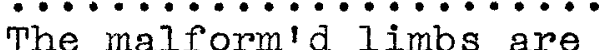
tied to the surgeon's table,

The quadroon Eiri is sold at the auction-stand, the drunkard nods by the bar-room stove,

The machinist rolls up his sleeves, the policeman travels his beat, the gate-keeper marks who pass,

The young fellow drives

the express-wagon...

The half-breed straps on his light boots to compete in the race.

(11. 264-273, 275, 277,

279-282 are taken from catalogue of occupations)
Is here one abhorring Fngland, and her institutions... Yonder walks one who has comitted, or is meditating, great crime...

There is a philosopher, to whose attuned ear the spectacle speaks myriad-tongued...

Here is a philanthropist-thinking of blood-stained slavery.

Here is one, little thinking that he will suddenly fall dead tomorrow...

There is one tottering under the weight of ninety years... Here sits a laughing child... Yonder is a blind man... (pp. $45-48$ taken from catalogue of intellect)

This comparative survey of the resemblances between the English and American poems helps one to see that the stylistic devices used in the composition of the "Song of Myself" are not at all unique.

Carl F. Strauch, in his article "The Structure of Walt Whitman's 'Sone of Myself""13 which appeared in the English Journal in September, 1938, Eives the first and most comprehensive study of the structure of the "Song of Myself." He takes no notice of the philosophic ideas of the poem except as they are related to form. 14 His analysis is cited: 15

13 Carl F. Strauch, "The Structure of walt Whitman's 'Song of Myself'," English Journal, September, 1938, 27:597-607.

14 Ibid., p. 599.

15 Ibid. 
1. Paragraphs 1-18, the Self; mystical interpenetration of the Self with all life and experience.

2. Paragraphs 19-25, definition of the Self; identification with the degraded, and transfiguration of it; final merit of Self withineld; silence; end of first half.

3. Paragraphs $26-38$, life flowing in upon the Self; then evolutionary interpenetration of life.

4. Paragraphs 39-41, the Superman.

5. Paragraphs 42-52, larger questions of life--religion, faith, God, death; imrortality and happiness mystically affirmed.

In the course of his interpretation Professor Strauch points up three ideas that are worthy of our consideration. First, the general structural pattern of the poem is divided into two main parts. ${ }^{16}$ The first division depicts expression; the second delineates impression. The first half (paragraphs 1-25) shows man as active--striving, storming experiencing. The great Self expresses itself in activity. But, in the second part of the poem (paragraphs 26-52), the Self is passive, mute, subject to the inflowing of impressions. The change is from objectivity to subjectivity, activity to passivity, selfconquest to a lucid contemplation.

Second, "...well-placed transitional passages and even single words"17 help to give order and form to the poem. One instance of the critic's cognizance of Whitman's artistry in making a single word pivotal 18 is seen in his explanation of the poet's use of the word 'kosmos' (1. 497) just following
16 Ibid.
17 Ibid., p. 606.
18 Ibia., p. 602. 
his claim to moistening "...the roots of all that has grown" (1. 467). It is because he sees himself as moistening the roots of all that has grown that he is able to see himself as a 'kosmos.'19 The word, as applied to the poet, emphasizes and gives another definition for the Self. 20

Third, the materials for the catalogues are gathered without any principle of selectivity. 21 strauch recognizes seven catalogues: 22

1. Paragraph 2: scattered and diverse phenomena of nature and ecstasies of Self in nature.

2. Paragraphs 8-18: mystical interpenetration; presence at a scene.

3. Paragraph 24: ethical interpenetration ending in transficuration.

4. Paragraph 26: sound.

5. Paragraphs 31-38: evolutionary interpenetration of life.

6. Paragraphs 40-41: the Superman; nystical interpenetration of life.

7. Paragraph 47: natural law and living is the key to the understanding of life.

Although Professor Strauch describes Whitman as an artist who is conscious of the movement and direction of his ideas, 23 he agrees with many other critics in their scorn of
19 Ibid.: :
20 Ibid.
21 Ibia., p. 606.
22 Ibid., pp. 604-605.
23 Ibia., p. 602. 
the catalogue method of gathering materials. 24 However, Mattie Swayne in her article "Whitman's Catalogue Rhetoric" 25 which appeared in the University of Texas Studies in English, 1941, claims that the catalogues were a deliberate part of Whitman's scheme and that they were never accidental. 26 In discussing the catalogues as an essential part of his poetic form she explains that: (1) the real object of his poetry is made clear in his theory of words, the principle of which rests on his belief that language serves its highest purpose when it resembles most nearly the things interpreted; 27 (2) his obsession to approximate as nearly as possible in words all

24 Ibid., p. 606. Professor strauch feels there is an absolute "... absence of any principle of selection..." in the catalogues.

Perry, op. cit., p. 306, declares that the "...stalks and heads of tangible matter..."--or, in other words, the catalogues--are the perishable portion of Whitman's poems. John Bailey, Walt Whitman, The lilacmillan Company, New York, 1926, pp. 57-58, refers to the catalogues as a part of the vulgar jargon acquired from the politics and journalism of the day. He claims that Whitman did not resort to enumeration in the best and more finished of his poems.

Bmory Holloway, Walt Whitman, an Interpretation in Narrative, Alfred A. Knopf, New York, 1926, p. 246, feels that the catalogues are representative of Whitman's early efforts and were never used except when inspiration was lacking.

Donald Davidson, "Regionalism in American Literature," The American Review, April, 1935, 5:51, claims that the cataIogues lack unity and do not persuade emotionally.

25 Mattie Swayne, "Whitman's Catalogue Rhetoric," University of Texas Studies in English, July, 194l, number 4126, pp. $162-178$.
26
Ibid., pp. 162-163.
27
Ibid., p. 163. 
natural, original, concrete, and divine things gave him a feeling of their unity and equality; 28 (3) the place of any object in his poetry was justified by the interpretative function of his own soul; 29 (4) because of a mystical feeling of equality of all objects and because of his spirit of acceptance of all things, Whitman would easily see relationships where others would see only differences; 30 (5) the poet's intuitive thinking as a mystic would encourage his listing of objects because the "...rapid fliashes of insight with which he viewed them would call for enumeration where he could not stop to elaborate." 31

Miss Swayne recognizes three separate patterns of catalogues which differ only in the degree of elaboration or expansion of the items Iisted. Because Whitman's theory of organic growth at work in his poetry appears to be explained by the idea of expansion and elaboration, the three different types of lists are cited:

1. Bare catalogues: 32 The structure is a series of words put together in a line without modification and followed by other lines just as bare. The plan is the same as that of a series of words used in a conventional sentence, but the structure is much expanded in the catalogue. There are very few of these lists although they appear frequently as a part of a line or sentence in

$$
\begin{aligned}
& 28 \text { Ibid. } \\
& 29 \text { Ibid., pp. 164-165. } \\
& 30 \text { Ibid., p. } 165 . \\
& 31 \text { Ibid., p. I66. } \\
& 32 \text { Ibid., pp. 170-I72. }
\end{aligned}
$$


the other two patterns.

Example: "Song of Myself," 11. 67-74.

2. A list of words modified or elaborated by adjectives or phrages and enumerated without structural alteration. 33 It is a series of words rather than a predication. In some instances (11. 833-837 of "Song of Myself") the terms are brought together in a structural conclusion, but in others (11. 21-29 of "Song of Myself") the terms are not made into a sentence.

3. Both the bare objects and those amplified by description are lengthened into dependent clauses or complete statements which become units in the catalogue. 34 Examples: Section fifteen of the "Song of Myself" is made up of sixty-five sentences, all beginning with the subject except for eleven interspersed lines that place modifiers first for variation. Section thirty-three of the "Song of Miyself"

is made up of eighty-one lines, chiefly adverbial phrases or clauses, all of which are brought together in the concluding line where the subject of the sentence is found. (This is an instance of a sentence being expanded so as to make a catalogue out of certain grammatical divisions.)

In addition to these three patterns the author asserts that in some groups of short stanzas there is enough correspondence to suggest a catalogue of stanzas. 35 (Example: 1]. 403 430, "Song of Myself")

Miss Swayne concludes her article with two main observations: (1) The "... amplification of the catalogue into stanzaic units says a great deal for the hold which the cumulative form had upon Whitman's style in general;36 (2) Whitman's constant use of the cumulative method in composing his poetry

$$
\begin{aligned}
& 33 \text { Ibid., pp. 172-175. } \\
& 34 \text { Ibid., pp. 175-177. } \\
& 35 \text { Ibid., p. 177. } \\
& 36 \text { Ibid. }
\end{aligned}
$$


was a planned feature of his art and was never accidental. 37

A more recent study of the "Song of Myself" is found in Gay Wilson Allents Walt Whitman Handbook, 38 published in 1946. It is encouraging to note that Allen's study concentrates on the psychological implications of the poem. He calls the poem a "...theme catalog..."39 and states that it serves "...as a program (not conscious, deliberate, and logical, but sub-conscious and intuitive) for the life poems." 40 His summary follows:

Section 1-4: intoxication by the joy of physical sensations; "But they are not the Me myself" (1. 74)

Section 5: mystical experience between 'He' and the soul, followed by mystical convictions

Section 6-8: symbolic pantheistic grass theme; life and death idea; develops thesis that it is just as lucky to die as to be born

Section 9-14: "Caresser of life;" transmigration of souls theory; souls moving along; vicarious experience with all life

Section 15: catalogue tour of occupations

Section 16-19: universal Christ-like sympathy expanded; kinship with all people; identity with general pattern

Section 20: worship of body

Section 2l: chant of dilation and pride

37 Ibid., p. 178 .

38 Gay Wilson Allen, Walt Whitman Handbook, Packard - and Company, Chicago, 1946, pp. 114-121, 267-269, 295-296, 396-398, 416-417, 419 .

$$
\begin{aligned}
& 39 \text { Ibid., p. } 130 . \\
& 40 \text { Ibid., p. } 116 .
\end{aligned}
$$


Section 22: accepts good and evil

Section 23: announces program of modernity

Section 24-30: therne of body as a temple; senses; procreation and fecundity

Section 31-33: "Caresser of life" again; pantheistic transmigration

Section 34-35: interpolated historical events themes

Section 36-40: vicarious suffering and sympathy

Section 41: new messiah appears a sermon

Section 42-51: the new messiah takes over; preaches

Section 52: new messiah says farewell, departs

The interpretation indicates that the form of the poem expresses "...an inner rather than an outer harrony" 41 for, according to Allen, the poet is more concerned with the spirit of relationships than with appearances. 42 His mystical acceptance of all things as equally divine and his identification of self with all objects in creation help him to achieve an inner harmony 43 which he expresses by means of enumeration and parallelism. Allen describes both of these stylistic devices as arising from the same psychological impulse and as achieving the same effects of poetic identification. 44 However, he claims that parallelism, the balancing of one thought alongside or against another, was used by the poet as his basic technique

\footnotetext{
41 Ibid., p. 382.

42 Ibid.

43 Ibid., p. 268.

44 Ibid., p. 399.
} 
for some time before he adopt ed the habit of enumeration. Allen gives three functions of parallelism in the "Song of Myself:" first, it provides the basic structure for the lines (each line makes an independent statement, either a complete or elliptical sentence); second, the repetition of thought units produces a loose rhythm or chant which results in a rhapsodic style; third, it binds the lines together and forms a unit something like a stanza. 45

The double expression of parallelism, the balancing of thoughts alongside or against each other, the actual reiteration of ideas more than likely led to the habit of enumeration. In any event the critic points to the catalogue as an essential structural device. 46 and he recognizes a close kinship between parallelism and enumeration when he describes the two long catalogues of the poem: first, in section fifteen, the poetic vision hovers over the occupations of the land and results in an enumeration of dozens of examples of "...more or less synonymous parallelistic form;"47 second, in section thirtythree, the poet's vision soars over a world panorama of scenes, activities, and pictures of life, finds expression in an eightyone line enumerative sentence of partial parallelisms, and is brought to a structural conclusion in the final line. 48 Allen concludes that the two forms of expression are

$\begin{array}{ll}45 & \text { Ibid., p. } 397 . \\ 46 & \text { Ibid., p. } 399 . \\ 47 & \text { Ibid., p. } 398 . \\ 48 & \text { Ibid. }\end{array}$


basic to the structure of the "Song of Myself" inasmuch as. they both arise from the same psychological expression of an expanding ego that would embrace the fullness and variety of nature in an organic whole. 49

In summing up it is encouraging to note that: (I) The correspondence in the structural motif of "The Song of Myself" and the Lily and the Bee helps to do away with any idea that the American poem is unique in design; (2) Professor Strauch's article demonstrates that the "Song of liyself" has a structural pattern; (3) Miss Swayne's study points out that the expansion and elaboration of the catalogue form is basic to the structural pattern of the poem; and (4) Professor Allen explains--naming parallelism and enumeration as the stylistic devices for expression--that the expanding ego psychology of identification with all creation is fundamental to the poem.

These studies move a long way from the mere mechanical analysis of form to a concentration on the psychological and philosophical implications of the poem. And this is in keeping with Whitman's plan that thought should ever outweigh form. 50 Yet it seems to me that these studies fail to do more than hint at the real structure of the "Song of Myself." It is my conviction that: (1) the poet's thought motif determines the general structural design of the poem; (2) this structural pattern accentuates the catalogue as an essential architectonic device; (3) the amplification of the simple catalogue

\section{Ibid., pp. 297, 399.}

50 Walt Whitman, Preface to 1876 Leaves of Grass, The Complete Writings of Walt Whitman. Vol. $5, \mathrm{p} \cdot 203$. 
xviii

into stanzaic units is basic to the structure; (4) the simple catalogue depends for its form on the poet's interest in single words. And I believe that an analysis of the poet's thought pattern, together with a consideration of his catalogue method of presentation and his special interest in words, will point up a clear picture of the structural design of the "Song of Myself." 
PART 1

GENERAL STRUCTURE 
PART I

GENERAL STRUCTURE

Introduction

The term 'structure' is significant in that it deals with the "fundamental ways of working of the human mind as an instrument in developing and in communicating thought." ${ }^{1}$ It has to do wi th the means that men use to put their thoughts and feelings in order. According to Plato every work of art is based upon some fundamental plan or design, every discourse "ought to be a living creature, having a body of its own and a head and feet; there should be a middle, beginning, and end, adapted to one another and to the whole." 2

Whitman appears to agree with Plato's concept. In any event, he gives us a similar definition of an organic work of art and indicates that his plan or design is the form of man:

I say that the perfect form, with all that with it goes, is only fully worthy. I think the human form the epitome of all the universal emblem... I think in literature... we will roam unsystematic and barbarous, except we seek ensemble through it and honor the actual fibres of things... acknowledging supreme above delicatesse and art, man, nude $_{3}$ and abysmal and indifferent to mere delicatesse and art. 3

And in an unpublished tract that was meant to serve as an introduction for an American edition of the Leaves, he tells

1 E. A. Saidla, Essays for the Study of Structure and Style, The Macmillan Company, New York, 1939, p. $4 \cdot$

2 The Dialogues of Plato, translated by B. Jowett, Random House, Inc., New York, 1937, 1:268.

3 Walt Whitman's Workshop, edited by Clifton Joseph Furness, Harvard University Press, Cambridge, 1928, p. 133. 
us that his works are meant

$$
\begin{aligned}
& \text {...namely to suggest the substance and form of a } \\
& \text { large, sane, perfect Human Being or character...4 }
\end{aligned}
$$

We shall take Whitman literally and seek to show that the "Song of Hyself" fits Plato's standard of a work of art. It is easy to view the poem as a man inasmuch as Whitman ascribes life to it when he embraces the whole content of his work in magnanimous gestures. In an unpublished appendix meant to appear as an introduction to Leaves of Grass, we find the words:

This is no book but I myself, in loving flesh and blood. 5 And, again in 1860, he says:

Camerado, this is no book, Who touches this touches a man. 6

This desire on the part of the poet to make us view his complete Leaves as a living creature is also evidenced in that part of the Leaves we are to study--"Song of Inyself." Plato's demand that a work of art must have a beginning, middle, end, is met in Whitman's poem of a living man with his birth (beginning), life (middle), death (end).

An overview of the thought pattern of the "song of Myself" is given in Chart 1 .

$$
\begin{aligned}
& 4 \text { Ibid., p. } 136 . \\
& 5 \text { Ibia., p. } 168 . \\
& 6 \text { "So Longl" The Complete Writings of Walt Whitman. }
\end{aligned}
$$
Issued under the editorial supervision of his isterary executors, Richard Maurice Bucke, Thomas Harned, and Horace Traubel, G. P. Putnam's Sons, New York and London, 1902. Vol. 2, p. 289, 11. 53-54. 
CHART 1

THE THOUGHT PATTERN OF THE "SONG OF MYSELF"

A. Beginning or birth (I-V)

- 1. Body comes from earth: My tongue, every atom of my blood
form'd from this soil.

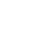

: 2. Soul enters body: ${ }^{8}$ I believe in you my soul...
Loafe with me on the grass...(11. 82,84)

: : $\quad$ B. Midale or life (VI-XIVII)

$\cdot \quad \cdot$

1. Life and death $(V I-V I I)$ : The smallest sprout shows

- there is really no death. (1. 126)

- 2. Pride of youth, questions (VIII-XXKVII)

: a. Diversity $(V I I I-X V I I) 9$

$:$ : $:$ o. Occupations $(X I I-X V I)^{9}$

$: \quad: \quad:$ c. Identity-sense (XVIII-XXXIl)

$\therefore \quad: \quad \dot{d}$ Experience (XXXIlI)

$\therefore \quad \cdot \quad$ a. Experienco (xxxili)

- $\quad \dot{e}$ Suffering (XXXIll-XXXVII)

- 3 . Sympathy of maturity, explanations (XXXVIII-XIIV)

a. Sympathy (XXXVIII-XLI)

$\therefore$

$\therefore$

b. The sermon starts (XLII-XLIV)

4. The sermon continues ( $X L V-X L V I I)$

Life and death: There is no stoppage and never can be stoppage. (1. 1190)

C. End or death (XLVIII-LII)

: 1. Soul leaves body: I depart as air...(1. 1337)

2. Body returns to earth: I bequeath myself to the dirt...(1. 1339)

lNotes $7,8,9$ : See following page. 
In all of Whitman's poetry, as in Emerson's, thought dominates over form. ${ }^{10}$ It is important to keep this fact in mind throughout the entire study of the poem for, when the poet's thoughts are put in order, the pattern of its structure appears.

The outline of the "Song of Iniyself" reveals a balance between the related parts which effects the subsequent unity of the whole. The poet's exact counterbalance of opposites-beginning and end, birth and death, youth and maturity, questions and explanations, pride and sympathy--appears to be based on the idea of the inherent opposing forces in nature and man. This two-handed theory of art ${ }^{1}$ achieves unity of

7 "Song of Myself," I. 6. All references to the "Song of Nyself" are made to volume one of The Complete Writings of Walt Whitman, issued under the editorial supervision of his Iiterary executors, Richard Maurice Bucke, Thomas Harned, and Horace Traubel, G. P. Putnam's Sons, New York and London, 1902. The Iine number of each succeeding reference to the poem will be enclosed in parentheses.

8 Clifton Joseph Furness, in the notes to his Walt Whitman's Workshop, $p .200$, has the following to say concerning such of the poet's expressions as 'Come, said my Soul,' and 'My Soul and I': "It seems almost certain that Whitman used the term 'Soul'...to indicate his Genius-self as distinct from his personal self." It is in this sense that the soul is posed as entering the body.

9 A general overlapping of thought motif in the lines of the midale portion of the "Song of Nyself" makes it almost impossible to say where one division ends and another division begins. This overlapping is particularly evident in the lines of diversity and occupations.

10 Norman Henry Pearson, "Literary Forms and Types; or, A Defense of Polonius," English Institute Annual, 1940, Columbia University Press, New York, 1941, p. 69.

11 Mary Austin, The American Rhythm, Houghton Mifflin Company, New York, 1930, p. 8 . 
the whole by effecting a balance of opposites. In Whitman's case the belief is that the one side does not exist without its opposite side 12 and, for this reason, the two opposites make up the whole. With this idea in mind it is easy to see the almost perfect balance between the first division, beginning, and the third division, end. The poet's body is seen as having both its inception and its end in the earth while his soul comes from and departs to an elusive source. This balance is between the opposite's, birth and death, beginning and end. However, the second division, or middle, pictures Iife itself and reveals a certain harmonic balance between youth and maturity, question and answer, pride and sympathy. Pride tends to isolate the individual while sympathy tends to fuse mankind. These polar opposites set up by Whitman effect a wholeness. He believed that the soul possesses sympathy as measureless as its pride and that neither pride nor sympathy can do harm when in the company of the other. ${ }^{13}$

The division of the poet's thought pattern into the three parts--beginning, middle, end--is only partially suggestive. The definitive requirements for a work of art demand much more than this surface treatment reveals. Therefore,

12 Floyd Stovall, "Whitman," American Idealism, University of Oklahoma Press, Norman, Oklahoma, 1943, p. 83.

13 Norman Foerster, "Whitman," American Criticism, Houghton Mifflin Company, New York, 1928, p. 210. 
in order to prove the harmony of the related parts one to. another and to the whole, a more detailed study is in order.

\section{Detailed Study}

In the detailed study of the "Song of Myself" the beginning, middle, and end will be referred to as the Introduction, Prelude, and Close. The terms fit the mood of the "poetmusician" 14 better inasmuch as the progression of his verse can be compared to that of musical composition. 15 Basil De Selincourt even declares that Whitman uses words and phrases as if they were notes of music. ${ }^{16}$ Gay Wilson Allen's observation that the progression is symphonic ${ }^{17}$ is applicable to the study of the "Song of Myself" where the Introduction (Sections I-V) actually advances themes that are developed in the prelude (Sections VI-XIVII). 18 However, because these themes are overlapping, it is never possible to say that any movement or idea begins and ends at a given point.

A general overview of the poem lends emphasis to Bliss Perry's observation that Whitman was particularly responsive

14 Gay Wilson Allen, Walt Whitman Handbook, Packard and Company, Chicago, 1946, p. 408 .

15 Basil DeSelincourt, Walt Whitman: a Critical Study, Nartin Secker, London, 1914, p. 104.

16 Ibid., p. 108.

17 Allen, op. cit., p. 407.

18 Pp. $12-14$ of this study. 
to all movement. 19 For instance, the first part of the poem stresses the sound of the human voice; the middle portion accents instrumental design in band or march music; and the concluding sections vibrate with the profound chords of the organ. Exemplified, the movement appears to be from the expression of physical lustiness in "...the belch'd words of my voice..." (1. 25), to the "...1ull...the hum..." (1. 86) of the mystical experience, and to the sound of the human voice in "The pure contralto sings..." (I. 264). But, "The bugle calls..." (1. 287) sets a new pace and anticipates the march motif of lines 361, 365-66:

With music strong I come, with my cornets and my drums,

I beat and pound för the de. $\ddot{\text { bad. }}$

I blow through my embouchures my loudest and gayest... Then, in section XXVI, we find a mixed motif of all kinds of sounds which describes the effect that music has upon the poet:

I hear bravuras of birds, bustle of growing wheat, gossip of flames, clack of sticks cooking my meals,

I hear the sound I love, the sound of the human voice,

I hear all sounds running together, combined, fused or following,

Sounds of the city and sounds out of the city, sounds of the day and night,

Talkative young ones to those that like them, the loud laugh of work-people at their meals,

The angry base of disjointed friendship, the faint tones of the sick,

The judge with hands tight to the desk, his pallid lips pronouncing a death-sentence,

The heave'e'yo of stevedores unlading ships by the wharves, the refrain of the anchor-lifters,

19 Bliss Perry, Walt Whitman, Hought on Mifflin Company, New York, 1906, pp. 86-87. 
The ring of alarm-bells, the cry of fire, the whirr of swift-streaking engines and hose-carts with premonitory tinkles and colorid lights,

The steam-whistle, the solid roll of the train of approaching cars,

The slow march play'd at the head of the association marching two and two,

(They go to guard some corpse, the flag-tops are draped with black muslin.)

I hear the violoncello, ('tis the young man's heart's complaint, )

I hear the key'd cornet, it glides quickly in through my ears,

It shakes mad-sweet pangs through my belly and breast.

I hear the cisorus, it is a grand opera,

Ah this indeed is music--this suits me.

A tenor large and fresh as the creation fills me, The orbic flex of his mouth is pouring and filling me full.

I hear the train'd soprano (what work with hers is this?)

The orchestra whirls me wider than Uranus flies,

It wrenches such ardors from me I did not know I possess'd them,

It sails me, I dab with bare feet, they are lick'd by the indolent waves,

I am cut by bitter and angry hail, I lose my breath, Steep'd amid honey'd morphine, my windpipe throttled in fakes of death,

At length let up again to feel...

(11. 584-609)

It is significant that Whitman uses the deep and penetrating chords of organ music to express the solemnity of the final or closing sections of the poem. Just before commencing his final farewell sernon, section forty-two, the poet tells us that "...he has pass'd his prelude on the reeds within..." (1. 1058), and refers to his poetry as "Easily written loosefinger'd chords..." (1. 1059). But, as he looks over the multitude he is to address, he becomes aware of the throbbing, 
pulsating crowd, the actual 'music' of living and breathing, and exclaims "Music rolls, but not from the organ" (1. 1061). It appears that Whitman's constant use of such vocal and instrumental devices in developing his ideas justifies the use of the terms Introduction, Prelude, Close as headings for the three divisions of the study. 
The Introduction $(1-V)$

A progressional theme is woven through the "Song of Myself." It appears that the poet starts at the ground and moves slowly but surely upward, step by step. In a symbolical sense, each separate progression merges into a whole picture and is representative of man's steady evolutionary advance. The Introduction serves as a starting point for the long journey; the Prelude pictures, in a series of progressions, man's journey through life; the Close serves as a point of return and brings the long journey to an end. The beginning or Introduction, the first five sections, indicates the themes or contents of the complete poem. It is really, in effect, a brief summary of the whole and charts the course for the movement of the entire song. My analysis of the Introduction will endeavor to point out themes which will carry over into the Prelude and become greatly enlarged upon there. In a sense these feelers have their roots in the Introduction, branch out in all directions in the Prelude, and are reduced to certain compact resolutions in the Close. In order to clarify the analysis of the Introduction as much as possible a brief structural chart of it, using the climax as the focal point, is presented. 
CHART 11

STRUCTURAL BALANCE OF FIVE SECTIONS OF INTRODUCTION

Section 1: Setting forth

Body and soul--separate parts

Section 2: Body

Catalogue: Sense impressions

Pride in body

Section 3: Climax

Wystery of life: Myself

Section 4: Soul

Catalogue: environment

Syrnp athy

Section 5: Conclusion

Body and soul--union

In the beginning, section one, the poet lets one know that he is to sing a song about 'Myself:'

I celebrate myself, and sing myself...(1.1)

This 'Nyself,' the main character of the song, is to be representative of all men:

And what I assume you shall assume...(I. 2)

He has his beginning in the earth:

My tongue, every atom of my blood, form'd from this soil...(1.6)

At first his body and soul are separate parts:

$$
\text { I...invite.my soul...(1. } 4)^{20}
$$

20 Refer to footnote eight on page four of this study. 
He endorses all natural laws:

I harbor for good or bad, I permit to speak at every hazard,

Nature without check with original energy. (11. 12-13)

Section two describes his joy in physical sensations.

The catalogue of sense impressions, quoted below, stresses

pride in body and serves as a brief surmary and introduction

for the enlarged "Song of the senses" found in sections twenty-four to thirty-one of the main body of the song, the Prelude:

Sight The smoke of my own breath,

Sight \& Echoes, ripples, buzz'd whispers, love-root Hearing silk-thread, crotch and vine,

Smell My respiration and inspiration, the beating Feeling of my heart, the passing of blood and air through my lungs,

Taste \& The sniff of green leaves and dry leaves, Smell and of the shore and dark-color'd sea-rocks, and of hay in the barn,

Hearing The sound of the belch'd words of my voice loos'd to the eddies of the wind,

Touch A few light kisses, a few embraces, a reaching around of arms,

Sight The play of shine and shade on the trees as the supple boughs wag,

Feeling The delight alone or in the rush of the streets, or along the fields and hill-sides,

Feeling The feeling of health, the full-noon trill, the song of me rising from bed and meeting the sun. (11. 21-29) 
This passage moves to the consideration, in section three, of the mystery of life. Because man has this body he debates about its beginning and end and comes face to face with the mystery of life:

I and this mystery here we stand. (1. 51)

With this statement the poet has reached a climactic plateau, and there is a short reflective pause while he philosophizes on the ego. The following lines serve as an introduction for the long 'I am' catalogue found in sections eighteen to twenty-four of the Prelude:

Showing the best and dividing it from the worst age vexes age,

Knowing the perfect fitness and equanimity of things, while they discuss I am silent, and go bathe and admire myself.

Welcome is every organ and attribute of me, and of any man hearty and clean,

Not an inch nor a particle of an inch is vile, and none shall be less familiar than the rest. (11. 55-58)

Both body and soul, section four, are recognized as equals and are subjected to environmental stimuli. The following catalogue pictures the trials that beset man's body on all sides:

Trippers and askers surround me,

People I meet, the effect upon me of my early life or the ward and city I live in, or the nation,

The latest dates, discoveries, inventions, societies, authors old and new,

My dinner, dress, associates, looks, compliments, dues,

The real or fancied indifference of some man or woman I love,

The sickness of one of my folks or of myself, or illdoing or loss or lack of money, or depressions or exaltations,

Battles, the horrors of fraticidal war, the fever of doubtful news, the fitiful events. (11. 66-72) 
But the poet stands apart from the agitation and turmoil for "...they are not the Me myself." (1. 74). This catalogue of confusion anticipates the long series of pictures of suffering with which the poet identifies himself in the prelude (11. 820-958).

In section five the poet's thoughts culminate in a mystical union of body and soul. This final section serves as a sort of conclusion for the Introduction. In it the body and soul, by means of a mystical experience, become united in a perfect whole. The offspring of the union of body and soul is love--the central key of the poem:

$$
\text { ... a kelson of the creation is love. (1. 95) }
$$

The union of body and soul anticipates the union of pride an d sympathy in the thirty-eighth section of the Prelude.

In looking back over the Introduction one cannot help but notice that the five sections seem to serve the purpose of pointing up a general structural pattern for the poem. That is, sections one and five are indicative of the beginning (Introduction $I-V$ ) and of the end (Close XIVIII-III) respectively, while sections two, three, four appear to be drawn as a summary and introduction for the middle portion (Prelude VI-XLVII). 
The Prelude (VI-XIVII)

The title prelude has been given to the middle portion of the "Song of Myself" because it is the term, though incorrectly used, which Whitman himself applies to the body of his song. In his own words, section forty-two, he lets us know that he has finished the main part of his song and is now faced with a climax and close. Or, in other words, he has lived the main part of his life and is now faced with the end or death.

Now the performer launches his nerve, he has pass'd his prelude on the reeds within,

Easily written loose-finger'd chords--I feel the thrum of your climax and close. (11. 1058-59)

According to Webster the term 'prelude' is defined as an introductory performance that prepares for the principal or more important matter. However, Whitman appears to have used the term more in a metaphorical sense to suggest his feeling that life is a prelude to death. He considers life as only a part of the whole; to be complete this whole is made up of both life and death. In this sense, when the author hints in section forty-two that he has passed his prelude, he means that he has said practically everything that needs to be said concerning life, and he starts to draw in or tighten up the loose chords of his song. Before section forty-two he has thrown out all kinds of ideas for consideration; starting with section forty-two he commences to resolve these ideas into certain compact explanations and 
reassurances for the Iife after death.

Whitman contends that his song is written for the express purpose of going beyond what is already understood about life. He says,

Not words of routine this song of mine, But abruptiy to question, to leap beyond yet nearer bring. (11. 1086-87)

For this reason it is, perhaps, easier to understand his-what may otherwise appear crude--method of presentation in the Prelude. He employs everytining he can think of from a tiny blade of grass--on through such minute objects as moth and fish-eggs (1. 352), quahaug (1. 613), pismire and egg of wren (1. 664), tree-toad (1. 665), running balckberry vine (1. 666), mouse (1. 669), gnat (1. 1253), a bean in its pod (1. 1274)--up to the spherical bodies of the universe (11. 1220-22) to prove that life is never-ending and that death is only a part of life. A glance at the outline of the poet's thought pattern on page three will show that he includes death as a part of life. For instance, he starts sections six and seven, and ends, section forty-seven, the Prelude with a consideration of life and death. The final resolution of sections six and seven:

The smallest sprout shows there is really no death. (1. 126)

serves as an introduction to the prelude of life and is counterbalanced by the thought: 
There is no stoppage and never can be stoppage. (1. 1190$)$

which serves as a conclusi on for the middle portion of the song.

Whitman sees man as moving ever onward. He refuses to tal $k$ of the beginning and the end (1. 39) for he sees nothing but a unified plan of procedure from one phase of life to another phase of life. He claims that death has no other purpose than to lead life forward (1. 127). If man is thought of, then, as living a fluid life, he is naturally thought of as moving about, one way or another, either forward or backward. And Whitman's American Character is one who moves "forward then and now and forever" (1. 696). The ultimate hope of his progressions is to come at last to God as a perfected man.

The Lord will be there and wait till I come on perfect terms. (1. 1199)

Whitman's concern with man's upward climb demands a pattern that will assure him of the necessary progression. And in the Prelude man appears, like Imerson's worm, 21 to be trying all of the time for something better. The linked spiritual progressions are built upon or, at least, have to do with catalogues. They start in sections six and seven, and end in section forty-seven. In order to present the progressions in a clear manner, three brief charts are offered: the first,

21 John Burroughs, The Writings of John Burroughs, Houghton Mifflin Company, New York, 1912, 14:202. 
A. Structural Outline of the Progressions (Chart 111), gives a detailed outline of the progressions; the second, The Balance of Progressions (Chart IV), supplements Chart 111 and points up a pattern of balance between the progressions; the third, A Structural Outline of Catalogues and Resolutions (Chart V), depicts a straight-line climb from one progression to the next. In this upward climb the catalogue is used as a stairway to a resolutional landing or plateau. Each catalogue is followed by a plateau which, in its turn, moves toward another catalogue and platéau. 
CHART 111

A STRUCTURAL OUTLINE OF THE PROGRESSIONS

Starting point $(I-V)$

PRELUDE

A. Throwing out of ideas: Man struggles for form and meaning

1. Progression one (VI-XIII)

a. Faith, no death (VI-VII)

"The smallest sprout shows there is really no death "(1. 126)

"Has anyone thought it lucky to be born?

...it is just as lucky to die..." (11. 131-132)

b. Catalogue of diverse life (VIII-XIII)

c. Caresser of life, animal and man (XIII)

"In me the caresser of life wherever moving..." (1. 232)

2. Progression two (XIII-XVII)

a. Identity with animal and outdoor Iife (XIII-XIV)

"I see in then and myself the same old law" (I. 252)

"I am enamour'd of growing out-doors" (1.255)

b. Catalogue of occupations (XV)

c. Identity with "...every hue and caste...every rank and religion" (i. 346)

3. Progression three (XVIII-XXIV)

a. Torch song, carries torch for the conquered and

slain, the wicked and righteous (XVIII-XIX)

b. Catalogue of identity, 'I am' (XX-XXIII)

"In ali people I see myself..." (1. 40I)

"To me the converging objects of the universe perpetually flow,

All are written to me, and I must get what the

writing means." ( $11.404-405$ )

c. Identity as 'Kosmos' (KXIV)

"Walt Whitman, a kosmos..." (1. 497)

"...through me the current and index." (1. 505)

4. Progression four ( $X X I V-X X X 11)$

a. Individual, Myself, hub of all (XXIV)

"walt Whitman, A kosmos..." (1. 497)

"... See then whether you shall be masterl" (1. 559)

b. Catalogue of senses, sex is key to constant flux of life (XXIV-XXXII)

c. Identity with creation (XXX-XXXI)

"AlI truths wait in all things" (1. 648) 
CHART $1 I I$

(continued)

5. Progression five (XXXII-XXXIII)

a. Identity with animal life (XXXIl)

"They bring me tokens of myself..." (1. 693)

b. Catalogue of experience, flow of inner vision (KXXIII)

"I am afoot with my vision" (1. 716)

c. Identity with Universal (XXXIli)

"I fly those flights of a fluid and swallowing soul, My course runs below the soundings of plumets. I help myself to material and imaterial, No guard can shut me off, no law prevent me."

(II. 800-803)

6. Progression six (XXXIII-XII)

a. Identity with suffering ( $\mathrm{XXXIII)}$

"All these I feel or am (1. 837)

b. Catalogue of suffering and sympathy, flow of inner vision $(X X X I I I-X I I)$

"I...embody all presences outlaw'd or suffering" (1. 947)

"...I do not give lectures or a little charity, When I give I give myself." (II. 994-995)

"I troop forth replenishtd with supreme power..." (1. 970)

"Ragnifying and applying come I" (1. 1026)

c. The new messiah appears (XLI)

"...myself waiting my time to be one of the supremes, ...when I shall do as much good as the best..." (11. 1050-1051)

"By my life-lumps! becoming already a creator" (1. 1052)

B. Drawing in, resolutions, realization of meanings

"...to question, to leap beyond yet nearer bring" (1. 1087)

7. Progression seven (XIII-XIVII)

a. The vision ends, the new messiah speaks ( $X L I I$ )

"A call in the midst of the crowd,

My own voice, orotund sweeping and final."

(11. 1054-1055) 
CHART 111

(continued).

b. The sermon, new messiah preaches, reconciliation of Iife and death

(1) Identity with Iife (XLII-XIV)

"Come my children" (1. 1056)

"One of that centripetal and centrifugal gang I turn and talk like a man leaving charges before a journey." (1. 1III)

"...let us stand up." (1. 1].34)

(2) The journey to death (XIVI)

"I tramp a perpetual journey..." (1. 1202)

"Not $I$, not anyone else can travel that road for you, You must travel it for yourself." (11. 12l0-1271)

"Perhaps you have been on it since you were born and did not know" (1. 1213)

"...after we start we never lie by again." (1. 1219)

"You are asking me questions...

I answer that I cannot answer, you must find out for yourself." (11. 1123-1124)

(3) Self-reliance (XIVII)

Point of return (XIVIII-LII)

22 The sermon is not a true catalogue, but it does represent a part of the progressions and moves to a resolutional plateau. 
CHART IV

BALANCE OF PROGRESSIONS*

1. Progression one (VI-XI1I)

a. Reconciliation of Iife and death (VI-VII)

b. Catalogue of diverse life, stanzaic form (VIII-XIII)

c. Identity with all life, both animal and man (XIII)

2. Progression two (XIII-XVII)

a. Identity with animal and outdoor life (XIII-XIV)

b. Catalogue of occupations, verse form (XV)

c. Identity with mass of mankind (XVI-XVII)

3. Progression three (XVIII-XXIV)

a. Individual, hub of all (XVIII)

b. Catalogue of 'I am', stanzaic form ( $X X-X X I I I)$

c. Identity as 'Kosmos' (XXIV)

4. Progression four (XXIV-XXXII)

a. Individual, hub of all (XXIV)

b. Catalogue of senses, stanzaic form (XXIV-XXXII)

c. Identity wi th creation $(X X X-X X X X)$

5. Progression five $(X X X I 1-X \times X I 11)$

a. Identity with animal life (XXXII)

b. Catalogue of experience, verse form (XXXIII)

c. Identity with Universal (XXXIII)

6. Progression siX (XXXIII-XII)

a. Identity with suffering ( $X X X I I I)$

b. Catalogue of suffering-sympathy, stanzaic form (XXXIII-XII)

c. Identity with Jesus, Jehovah, and old religionists (XXXVIII, XII)

7. Progression seven (XLII-XLVII)

a. Sermon (XIII-XIVII)

b. Reconciliation of life and death (XIV-XIVI)

* This supplement is condensed from Chart 1ll, pp. 19-21, and points up the relationship between the progressions. 


\section{CHART V}

A STRUCTURAL OUTLINE OF CATALOGUES AND RESOLUTIONS 23

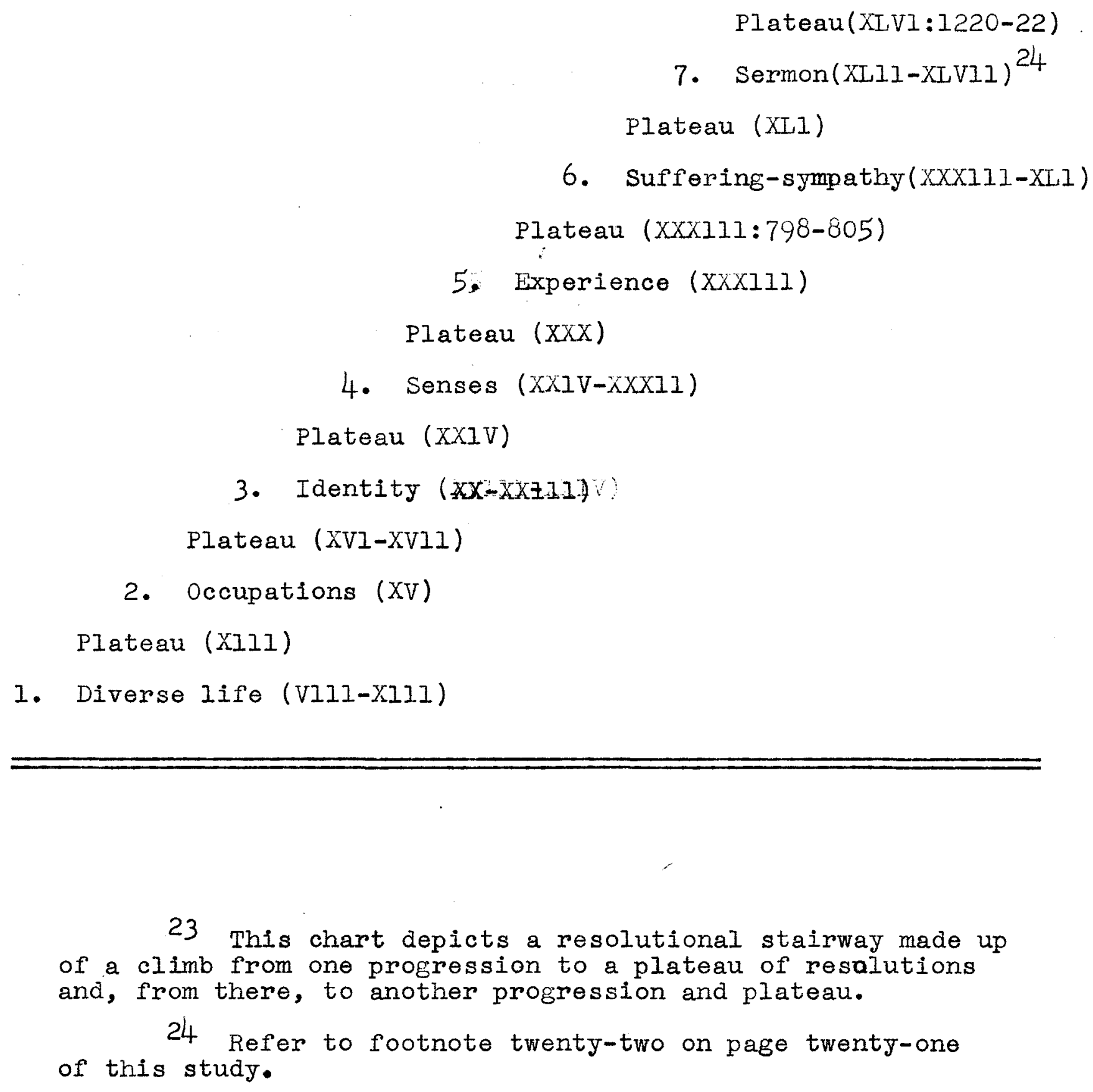

23 This chart depicts a resolutional stairway made up of a climb from one progression to a plateau of resalutions and, from there, to another progression and plateau.

24 Refer to footnote twenty-two on page twenty-one of this study. 
The pyramidal movement of Charts $11 I$ and $I V$ reveals a structural pattern which appears to have had its inception in the poet's struggle to ascribe form and meaning to life or Being. The movement has its beginning in a reconciliation of Iife and death in progression one:

The smallest sprout shows there is really no death. (1. 126)

Following this, the quest for understanding of the mystery of Being gets under way. It is traced through the divisions of diversity, occupations, identity, to the song of the senses where the poet finds that sex is the key to life. The revelation of the secret of Being results in the flow of the poet's inner vision which can be traced on through the divisions of experience and suffering-sympathy. Then, all six of the divisions are pulled together in a final realization of meanings, a reconciliation of life and death, in progression seven:

I know I have the best of time and space, and was never measured and never will be measured. (1. 1201)

This movement will be traced in a brief analysis of the progressions.

Progression one (Sections VI-XIII). The progression starts on a note of questioning uncertainty (Sec. VI). The poet is unable to answer the question, "What is the grass?" (1. 99). But he doer make a series of guesses which develop the symbol of the pantheistic grass:

I guess it must be the flag of my disposition... Or I guess it is the handkerchief of the Lord, 


\begin{abstract}
Or I guess the grass is itself a child, the produced babe of the vegetation.

Or I guess it is a uniform hieroglyphic,

And now it seems to me the beautiful uncut hair of graves. (11. 101-102, 105-106, 110)
\end{abstract}

And, in attempting to determine what has become of those who Iie under the grass, he reconciles life and death:

They are alive and well somewhere,

The smallest sprout shows there is really no death, And if ever there was it led forward life, and does not wait at the end to arrest it, And ceas'd the moment life appearld.

All goes onward and outward, nothing collapses, And to die is different from what any one supposed, and luckier. (11. 125-130)

The first two lines of section seven reiterate this reconciliation of Iife and death:

Has any one supposed it lucky to be born?

I hasten to inform him or her it is just as lucky to die, and I know it. (11. 131-132)

This is followed by what appears to be a 'try' at a vision. He says:

I pass death with the dying and birth with the new-wash'd babe, and am not contain'd between my hat and boots, And peruse manifold objects... (11. 133-134)

But he gets down to mere listing and gives a summary of what is to come in the catalogue of diversity(Sec. VIII-XIII) and occupations (Sec. XV). He prefaces the list with "I am the mate and companion of people..." (I. 137), follows with a summary listing of the kinds of people he is to embrace: 
For me those that have been boys and that love women, For me the man that is proud and feels how it stings to be slighted,

For me the sweet-heart and the old maid, for me mothers and the mothers of nothers,

For me lips that have smiled, eyes that have shed tears,

For me children and the begetters of children.

(11. $140-144$ )

and then points up his relationship to the coming catalogue

of diverse Iife as that of a bystander only. He sees:

Undrapel you are not guilty to me, nor stale nor discarded,

I see through the broadcloth and gingham whether or no,

And am around, tenacious, acquisitive, tireless, and cannot be shaken away. (11. 145-147)

In the non-experiential catalogue of diverse life (sec. VIIIXI11), which follows, the poet's role as an onlooker serves as his only means of contact with the aiverse mass of humanity. Notice that the lines of identification stress observation only:

I lift the gauze and look a long tine...(1. 149)

I peeringly view them...(1. 151)

I witness the corpse...(1. 153)

I mind them....(1. 166)

ivy eyes settle the land...(1. 181)

I saw the marriage...(1. I85)

...for I see you...(1. 206)

I follow their movements... (I.221)

I behold the picturesque giant...(1. 230)

It is important to notice that up to this point the poet's observation of the human spectacle has drawn forth very little feeling. But, in section Xlll, when he beholds the driver of the stone-yard wagon, his eyes "...go with the team also..." (I. 231), and he becomes the "...caresser of Iife..." (1. 232), both animal and man. Then when his eyes 
fall upon the wood-drake and the wood-duck, the resolutional plateau of progression one is achieved. For, as he stands. and looks on at the high flight of the feathered creatures, he has a feeling of kinship with them and expresses his belief in pantheistic evolution:

I believe in those wing'd purposes, And acknowledge red, yellow, white, playing within me. (II. 239-240)

Following this he proceeds to accept the tortoise (1. 242), the jay in the woods (1. 243), the bay mare (1. 244) on their own terms.

Progression two (Sections XIII-XVII). The poet extends his identification with animal life to include the wild gander (1. 24.5), the moose (1. 249), the cat on the house-sill (1. 249), the chicadee (1. 249), the prairie-dog (1. 249), the litter of the grunting sow (1. 250), the brood of the turkey hen ( 1.251 ), and sees "...in them and myself the same old law" (1. 252) of pantheistic evolution and transmigration. (It is this spirit of humility before animal life that serves as the open door to the lone verse catalogues.)

Then the press of his "... foot to the earth springs a hundred affections" (1. 253), and he proceeds to identify himself with out-door life. He gives us a short list of out-of-door people which serves as a preface to the catalogue of occupations $(X V)$ :

of men that live among cattle or taste of the ocean or woods, of the builders and steerers of ships and the wielders of axes and mauls, and the dpifyers of horses. (11. 256-257) 
The final five lines of section fourteen:

What is commonest, cheapest, nearest, easiest, is ine,

the going in for my chances, spending for vast returns, Adorning myself to bestow myself on the first that will take me, Not asking the sky to come down to my good will, scattering it freely forever. (11. 259-263)

describe 'Me' and anticipate the catalogue of identity, sections twenty to twenty-three, in progression three. The catalogue tour of occupations (Sec. XV) leads to a general summary of the diversity of being (Sec. XVI) and a final sympathetic identification with the common pattern of mankind:

of every hue and caste am I, of every rank and religion,

I resist anything better than my own diversity, $(11.346,349)$

Section XVIl serves the purpose of drawing all of the ideas expressed in the first two progressions into a conclusion. In it, the poet refers to the pattern of diversity encountered in sections seven to sixteen as "...the grass that grows wherever the $I$ and is and the water is" (I. 389) and, thus, has the answer--"...the untying of the riddle..." (1. 357)--to the question he could not answer in section six - "What is the grass?" (1. 99) 
Progression three (Sections XVIII-XXIV). Section eighteen is a brief torch song for the "...conquer'd and slain..." (1. 362). The poet makes it clear that he identifies himself with the dead just the same as the living. I beat and pound for the dead (1. 365)

Then, in section nineteen, he takes on a Christ-like sympathy for the wicked and righteous (1. 373), the kept-womm (1. 375), the sponger (1. 375), the thief (1. 375), the heavy-lipped slave (1. 376), the 'venerealee' (1. 376) and invites them all to the "...meal equally set..." (372), to the "...thoughtful merge of myself..." (1. 381).

But in section twenty he moves away from the group to a consideration of one individual, himself, for he feels that nothing has significance except as it is related to "...the Me in the centre..."25 (11. 404-405). He sets up a triple question of being--"What is man, anyhow? what am I? what are you?" (1. 391)--and proceeds to an answer by isolating one part of the question--"What am I?"--for study. His thinising appears logical in that he recognizes that one individual carries within himself all of the characteristics of the group:

In all people I see myself. (I. 40I) and concludes that what is found to be true in the instance of the individual will also be true of the masses:

All I mark as my own you shall offset it with your own. (1. 392)

Before moving into the 'I am' song of identity Whitman lets 
us know that he is seeking the 'why' of life:

To me the converging objects of the universe perpetually flow,

All are written to me, and I must get what the writing means. (11. 404-405)

It is seen that the poet moves to a consideration of himself in order to ascribe a plan or order tothe universe. And, in the midst of his arrogant song of 'I am' ('Sec. XX-XXIII) he finds himself to be an orderly and harmonious system, a part of the whole:

I exist as I am...

one world is aware and by far the largest to me, and that is myself. (11. 413, 416)

This Iink-in-the-chain theory of perfection leads to a chant of dilation and pride in section twenty-one. The poet sees himself as a perfect whole in the cosmic scheme and concludes that size does not matter.

I show that size is only development. (1.430)

His concept of evolutionary progress sees all men arriving at the highest point and then passing on, sees all men as living a while and then dying:

Have you outstript the rest?...

It is a trifle, they will more than arrive there every one, and still pass on (11. 431, 432)

He even proceeds to identify himself with the earth and sea. And the imagery of the earth and sea songs (11. 433-458) becomes symbolic of life and death. For the picture of the

Earth of the slumbering and liquid treest

Earth of the departed sunset...

Earth of the vitreous pour of the full moon... 
$\ldots \ldots \ldots \ldots \ldots \ldots \ldots \ldots \ldots \ldots \ldots \ldots \ldots \ldots \ldots \ldots \ldots \ldots \ldots \ldots \ldots$

Earth of the limpid gray of clouds...

(II. 439-441, 443)

is one of rest while the picture of the

Sea of stretch'd ground-swells,

Sea breathing broad and convulsive breaths,

Sea of the brine of life...(11. 454-456)

is one of pulsating life.

Section twenty-three expounds the achievements of modern science. The poet accepts these scientific facts (1I. 485-490), but he does not feel that science explains human existence, or 'myself:'

Your facts are useful, and yet they are not my dwelling,

I but enter by them to an area of my own dwelling (11. 491-492)

So he turns away from science back to a consideration of himself for the answer to the eternal question. He has previously declared himself done with "Whimpering...truckling... conformity...ducking...deprecation..." (11. 396, 429) and is now ready to give a climax to his chant of dilation and pride by declaring that he is a "Kosmos" (1. 497).

His assumption of the new role is not an unnatural act for, from the very first lines of the poem, the poet's pride in self has been growing steadily stronger. The identification has moved from the general and diverse pattern of mankind to an accent and repeated stress on the individual, on II las the center of the universe. It is no small wo nder 
that the supremacy accorded Witman's 'I am!26 in the catalogue of identity should move to a projection of himself as a 'Kosmos' (Sec. XXIV).

Progression four (Sections XXIV-XXXXI). The theme of the 'I am' catalogue of identity, progression three--to praise the individusl and make him supreme--continues on through section twenty-four of progression four. "Walt Whitman, a kosmos..." (1. 497), by declaring that he is the "...current and index..." (1. 505), becomes a medium through which all cosmic 'voices' speak:

Through me man y long dumb voices,

Voices of the interminable generations of prisoners and slaves, Voices of the diseas'd and despairing and of thieves and dwarfs, Voices of cycles of preparation and accretion, And of the threads that connect the stars, and of wombs and the father-stuff, And of the rights of them the others are down upon, of the deform'd, trivial, flat, foolish, despised, Fog in the air, beetles rolling balls of dung. (11. 508-515)

And because nothing in nature is indecent, her spokesman will find nothing indecent 27 in the

-.. forbidden voices,

Voices of sexes and lusts, voices veil'd and $I$ remove the veil,

Voices indecent by me clarified and transfigur'd.

I do not press my fingers across my mouth,

I keep as delicate around the bowels as around the head and heart,

Copulation is no more rank to me than death is. (11. 516-521)

26 The Biblical definition of the word 'Jehovah' as "I am that I am" (Exodus $3: 14$ ) is a possible explanation of the 'I am' catalogue ố identity.

27 Allen, op. cit., p. 297. 
Then he proceeds to an arrogant worship of his own body:

Divine am I inside and out, and I make holy whatever I touch or am touch'd from,

The scent of these arm-pits aroma finer than prayer,

This head more than churches, bibles, and all the creeds.

If I worship one thing more than another it shall

be the spread of my own body, or any part of it,

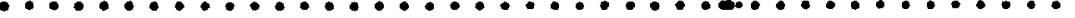

I dote on myself, there is that lot of me and all so luscious. (11. 524-527, 544)

The poet's intoxication with his own body and with the joy of physical sensations strengthens, his desire to understand the source of Being. And the 'Kosmos' carries the motif of the 'I am' catalogue to its climax when he accepts the challenge, "... See then whether you shall be masterl" (1. 559)

His search for some method of control can be traced through the catalogue of the senses. In the first lines of section twenty-five the poet recognizes that he possesses an inherent power for self destruction:

Dazzling and tremendous how quick the sun-rise would kill me,

If I could not now and always send sun-rise out of me. (11. 560-561)

But he is unable to find words that will explain creation. He finds it impossible to express what he really is in mere words:

My final merit I refuse you, I refuse putting from me what I really am (1. 576)

and claims that a look tells more than any word:

I crowd your sleekest and best by simply looking toward you (1. 578)

Because it is impossible to explain in words, he becomes silent: 
With the hush of my lips I wholly confound the skeptic (1. 581)

and decides to "...do nothing but listen" (1. 582).

The catalogue of sounds, section twenty-six, 28 is divided into two parts: the first, lines 584-595, gives a list of sounds heard in everyday living; the second, lines 596-610 , accents music and its erfect upon the poet. The poet is receptive to the first kind of sound, but he is completely overcome by the sound of music. He loses his breath (1.607) and is left in a 'drugged' state "Steep'd amid honey'd morphine" ( 1 . 608) with his "...windpipe throttled in fakes of death" (1. 608). But after awhile his mind is clear, and he ponders the question of Being asdin:

At length let up again to feel the puzzle of puzzles, And that we call Being (11. 609-610)

Section twenty-seven projects the theme of 'Touch.' The poet asks, "To be in any form, what is that?" (1. 611) and notices that he is still asking the same question he posed earlier in progression three (1. 391). He observes--in a cycle-of-life theory--that we always come back to the same old question:

(Round and round we go, al I of us, and ever come back thither) (1. 612)

In an attempt to explain Being he moves from a consideration of the undeveloped "...quahaug in its callous shell..." (1.613) to the more highly developed lie' with "... instant conductors all over..." (1. 615) and calls attention to his own acute sensitivity to touch:

28 The catalogue of sounds is quoted on $\mathrm{pp}$. 7-8 of this study. 
I merely stir, press, feel with my fingers, and am happy,

To touch my person to some one else's is about as much as I can stand. (11.617-618)

Then, in section twenty-eight, under the tyranny to the "...red marauder" (1. 625), touch, the supremacy accorded Whitman's 'I am' in the catalogue of identity is swept away. The poet is overcome by his emotions and abandons reason for sexual ecstasy. The "...fellow-senses..." (1. 629) are described as being bribed by "...villain touch..." (1. 640) to "...80 and graze at the edges of me" (1. 630).

Section twenty-nine describes the aftereffects of the release of the poet's sexual emotions:

$$
\begin{aligned}
& \text { Rich showering rain, and recompense richer } \\
& \text { afterward. } \\
& \text { Sprouts take and accumulate... (11. 645-646) }
\end{aligned}
$$

and gives him the key to the mystery of Being. He recognizes that all of the time he has carried the answer to the question of life within himself. For it is by means of sex that his soul has received its identity, and it is by means of sex that the entire race is kept moving and the perpetual laws fulfilled. 29 The answer to the question of Being leads to the resolutional plateau of progression four (Sec. $\mathrm{XXX}$ ) in wich the poet asserts that each person or thing carries the truth within himself. Feeling is creative:

All truths wait in all things (1. 648)

29 Allen, op. cit., p. 269. 
Then, the poet observes that: (1) The logic of science did not give him the answer to the question of existence:

Logic and sermons never convince,

The damp of the night drives deeper into my soul. (11. 653-654)

(2) Every man and woman must prove the truth for themselves, through sex:

(Only what proves itself to every man and woman is so

Only what nobody denies is so.) (11. 655-656)

(3) It takes only a moment of experience, by sex, to understand creativity and the source of Being:

A minute and a drop of me settle my brain (1. 657) The over-beliefs of section thirty (1I. 658-662) flow into and become a part of the eneral pattern of section thirty-one. The poet's pantheistic philosophy is seen in such lines as:

I believe a leaf of grass is no less than the journey-work of the stars (1.663)

By the light of the cosmic sense all things are perfect, 30 and the poet notes the minute miracles of everyday life: leaf of grass (1. 663); pismire, grain of sand, egg of wren (1. 664); tree-toad (1. 665); running blackberry (1. 666); cow (1.668) mouse (1. 669). But the chief miracle of the universe is 'I' who incorporates all:

I ind I incorporate gneiss, coal, long-threaded moss, fruits, grains, esculent roots, And am stucco'd with quadrupeds and birds all over. (11. 670-671)

30 Richaro Haurice Bucke, "Walt Whitman," Cosmic Consciousness, E. P. Iutton and Company, Inc., Niew York, $1901, \mathrm{p} \cdot 235$. 
and wh o has "...istanced what is behind..." (1. 672). This hint of evolutionary transmigration moves into a listing of animal Iife--mastodon (1. 676), buzzard (1. 679), snake (1.680), elk (1. 681), "razor-bill'd auk" (1. 682)--which anticipates and sets in motion the animal motif of section thirty-two. Progression five (Sections XXXII-XXXIII). The poet asserts (Sec. XXXII) that he could "...turn and live with animals..." (1. 684) because their characteristics are superior to those of man. That is:

They do not sweat and whine about their condition, sins,

They do not lie awake in the dark and weep for their God,

They do not make me sick discussing their duty to

Not one is dissatisfied, not one is demented wh the mania of owning things,

Not one kneels to another, nor to his kind that lived thousands of years ago,

Not one is respectable or unhappy over the whole earth. (11.686-691)

He recognizes that they bring him 'tokens' of himself but hastens to suggest that this is only because he,himself, passed their way "...huge times ago..." (1. 695) and dropped them. Then he calls attention to the fact that he did not stay with the animals but kept "...moving forward then and now and forever" (1. 696). And, finally, he asserts that he has outdistanced the animals, has outstripped their pace (11. 707-709).

The poet's understanding of the perfection and equality of all things--together with his sympathetic feeling of kinship with animal life--is the force which starts the climactic flow of his inner vision in section thirty-three. The release 
of the vision is seen in: (1) Progression five, in the catalogue of experience (11. 717-797) and his identification with the cosmic plan, the universal (11. 798-805); (2) Progression six, in the lines of suffering (11. 819-958) and his identification with suffering (11. 832, 837, 946-947); (3) Progression six, in the lines of sympathy (11. 959-1053) and his identification wi th Jesus (11. 963-965), Jehovah (1. 1028), and all of the old religionists (11. 1029-1033).

The vision gets under way (Sec. $X X X I I I$ ) when the poet puts material or earthly "...ties and ballasts..." (1. 714) aside and declares "I am afoot with my vision." (1. 716). And the eighty-one lines which follow depict the inflowing of phenomena which makes up the 'path' the poet's mind travels:

I tread day and night such roads (1. 797)

It is, perhaps, significant that Whitman starts the flow of experiential impressions "afoot" (1. 716) and, al so, that he closes the eighty-one line sentence with "I tread..." (1. 797). In a symbolic sense, these terms might possibly imply a journey on foot in which the range of his vision is somewhat confined. In any event, when he reaches his resolutional plateau (11. 798-805) he lets one know that his journey from there on is to be on a wider more universal range, for he is to soul $\because$ (ly those flights of a fluid and swallowing 
His course is not to be confined but will run ...below the soundings of plummets (1. 801) His vision is to embrace material and immaterial for No guard can shut me off, no law prevent me (1. 803) In other words his vision is to penetrate not only the body and exterior, but the very soul of man.

Progression six (Sections XXXIII-XLI). The flow of the poet's vision continues on to the catalogue of suffering (II. 819-958) where his pride in heroism and martyrdorn is accentuated. The third sentence of the division: ${ }^{31}$

I understand the large hearts of heroes,

The disdain and caimess of martyrs (il. 822, 833) gives the theme or central idea for the entire list of suffering.

After describing a skipper's rescue of passengers from an ice-bound steamship (11. 824-830) as an example of heroism and depicting a "...mother...condemn'd for a witch..." (1. 834) and a "...hounded slave that flags in the race..." (1. 835) as examples of mantyrdom, the poet identifies himself with suffering:

All these I feel or am (1. 837)

Next, he experiences vicariously the suffering of the "...hounded slave" (11. 835-846), the "mash'd fireman" (11. 847-857), and

31

This sentence is representative of the poet's method of expanding a single sentence into larger units. In this instance the sentence (11. 822 and 833) is extended and made into two stanzaic units (1I. 822-832, 833-837). 
the "old artillerist" (11. 858-870).

At this point the poet breaks into the pattern of the catalogue to interpolate two historical events: the first, (Sec. $X X X I V$ ), refers to the massacre of Fannin and his men at Goliad, March 27, $1836^{32}$ and serves as a good example of martyrdom; the second, (Sec. XXXV), an old-time sea fight, probably suggested by a letter from John Paul Jones to Benjamin Franklin, 33 depicts heroism.

Section thirty-six describes the aftereffects of the sea fight. The poet's pride in heroism is overcome by the suffering of the wounded sailors and prisoners of the ship. It is significant to note that when his pride in heroism is overcome he is able to feel real sympathy for the sufferers. INe proceeds (Sec. XXXVII) to identify himself with all suffering:

...I am possessidl

Embody all presences outlaw'd or suffering (11. 946-947) and even sees himself as the convict "... Iet out in the morning..." (1. 95I), the mutineer who "...walks handcuff'd to jail..." (I. 952), the "...youngster taken for larceny..." (1. 954), the cholera patient who "....lies at the last gasp..." (1. 955).

Then, in the resolutional plateau, section thirty-eight, the poet is seen as reaching a climactic point of endurance

32 Walt Whitman, edited with an introduction, bibliography, and notes by Floyd Stovall, American Book Company, New York, 1934, p. 458 . 
in suffering:

Enough! enough! enough

Somehow I have been stunn'd. Stand backl

(11. 959-960)

However, he remembers the suffering and resurrection of Christ (11. 963-969), reminas himself that "Corpses rise, gashes heal..." (1. 969), and is transfigured by his feeling of love and sympathy, is "...replenish'd with supreme power..." (1. 970).

This power is personified in the "...friendly and flowing savage..." (Sec. $X X X I X)$ who is, perhaps, symbolic of the sympathetic love which the poet now feels. He is described as being desired wherever he goes (1. 981) and as having

Behavior lawless as snow-flakes, words simple as grass...

Slow-stepping feet, common features, cominon modes and ernanations (11. 983-984)

The poet's feeling of power moves from the 'friendly and flowing' sympathy of section thirty-nine to the more compelling 'superman' type in section forty where he tells us that his love and sympathy spread more actual warmth than do the rays of the sun:

Flaunt of the sunshine I need not your bask--lie over

You light surfaces only, I force surfaces and depths also. (11. 987-988)

This arrogant suggestion that the power of his love and sympathy surpasses the power of the sun makes one wonder, in reading the following lines, if he thinks the earth is looking for warmth at his hands: 
Earth you seem to look for something at my hands, Say, old top-knot; what do you want? (11. 989-990)

The flow of his sympathetic love moves from:

$$
\begin{aligned}
& \text { Man or woman, I might tell how I like you, but } \\
& \text { cannot, } \\
& \text { And might teil that pining I have, that puise } \\
& \text { of my nights and days. (II. 991, 993) }
\end{aligned}
$$

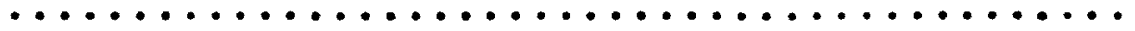

to:

Behold, I do not give lectures or a little charity, When I give I give myself. (1I. 994-995)

Next, he embraces the"...jimpotent, loose in the knees..." (1. 996), the "...cotton-field drudge..." (1. 1003), the "...cleaner of privies..." (1. 1003), the "...woman fit for conception..." (1. 1006):

You can do nothing and be nothing but what I will infold you. (1. 1002)

and gives hope to the dying man: up,

I dilate you with tremendous breath, I buoy you force,

Every room of the house do I fill with an arm'd

Lovers of me, bafflers of graves. (11. 1014-1016)

The "...magnifying and applying..." (1. 1026) superman role continues on into section forty-one where the poet identifies himself with Jehovah (1. 1028) and the leaders of the old religions (11. 1029-1032) and, thus, assumes the role of a new 'Messiah.' He accepts the "...rough deific sketches..." (1. 1036) of the past for "... what they are worth and not a cent more..." (1. 1033) and to "...fill out better in myself, bestowing them freely on each man and woman I see" (I. 1036). 
The sympathetic and all-inclusive sweep of his vision sees: the "...framer framing a house..." (1. 1037) as possessing god-like qualities; the "... lads ahold of fire-engines..." (1. 1040) as representing the "... gods of antique wars..." (1. 1040); the "...mechanic's wife with her babe at her nipple interceding for every person born..." (1. 1043) as the holy Wother and Child; the three farmers as "...three Iusty angels..." (1. 1044); the "...snag-tooth'd hostler with red hair... Selling all he possesses...to fee lawyers for his brother..." (11. 1045-1046) as possessing Christ-1ike Iove. And when his vision moves away from the consideration of the god-like attributes of the mixed group to a deliberation of his own qualities, he finds that he, too, is waiting his "...time to be one of the supremes..." (1. 1050) when he shall "...do as much good as the best..." (1. 10.51). Finally, he reaches the climax of his vision when he declares:

By my Iife-lumps! becoming already a creator, Putting myself here and now to the ambush'd womb of the shadows. (11. 1052-1053)

Progression seven (Sections XIII-XIVII). In section forty-two the vision ends, and the poet speaks out:

A call in the midst of the crowd, Ify own voice, orotund sweeping and final. (11. $1054-1055$ )

Then, in his new Messianie role, he prepares for his parting address or sermon by entering what appears to be a poetic trance: 
44

Why head slues round on my neck, Music rolls, but not from the organ, Folks are around me, but they are no household of mine. (11. 1060-1062)

He pictures the human spectacle of everyday living, the ever "...sobbing liquid of life..." (1. 1068), the

Many sweating, ploughing, thrashing, and then the chaff for payment receiving,

A few idly owning, and they the wheat continually claiming. (11. 1073-1074)

He identifies himself as one of the "citizens" (1. 1075) of this kind of life, but raises the question as to the reason of it all:

And what is reason? and what is love? and what is life? (1. 1095)

From this point on his sermon resembles those of the founders of the old religions. In fact, he accepts all of the old priests (Sec. XIIII) and even identifies himself as belonging to their "...centripetal and centrifugal gang..." (1. 1111). Then, he turns and talks "...like a man leaving charges before a journey..." (1. 1111), identifies himself with the "Down-hearted doubters dull and excluded..." (1. 1112), and admits that he is like them for he does "...not know what is untried and afterward..." (I. 1121). However, he hastens to add that he does know that whatever it is M...itiwizlin its turn prove sufficient, and cannot fail" (1. 1122). Then he proceeds to an explanation (Sec. XLIV): It is time to explain myself--let us stand up. What is known I strip away, I launch all men and women forward with me into the Unknown. (11. $1134-1136$ ) 
and reveals his theory of pantheistic evolution in a review of life which starts with the "..huge first Nothing..."

(1. 1153) before birth:

Before I was born out of my mother generations guided me,

iny embryo has never been torpid, nothing could overlay it. (11. II62-1163)

moves to his actual being:

Now on this spot I stand with my robust soul. (I. 1169) his youth and manhood:

O span of youth! ever-push'd elasticity!

0 manhood, balanced, florid and full. (11. 1170-1171)

his old age and dying days:

old age superbly rising! o welcome, ineffable grace of dying days $(1.1180)$

and the final resolutions:

There is no stoppage and never can be stoppage,

Mily rendezvous is appointed, it is certain,

The Lord will be there and wait till I come on perfect terms... (11. 1190, 1198-1199)

The Messiah's review of life, sections forty-four and forty-five, gives place, in section forty-six, to a depiction of the journey to death. First, he reconciles Iife and death:

I know I have the best of time and space, and was never measured and never will be measured. (1. 1201) Next, he adopts the negative language of mysticism to describe the 'beyond.' For example, he describes the unknown journey by refusing to describe at all: 34

34 Evelyn Underhill, "The Mystic as Creative Artist," The Essentials or Mysticism and Other Essays, J. IV. Dent and Sons, Ltd., London and Toronto, 1920, p. 72 . 
Not I, not any one else can travel that road for you,

You must travel it for yourself. (11. 1210-1211)

and refuses to answer questions about the unknown:

You are asking me questions and I hear you,

I answer that I cannot answer, you must find out for yourself. (11. 1223-1224)

Then he implies that the journey to death is neverpending:

... after we start we never once lie by again (1. 1219)

and moves to a resolutional plateau in which man is seen as always progressing, always moving forward:

This day before dawn I ascended a hill and look'd at the crowded heaven,

And I said to my spirit 'When we become the enfolders of those orbs, andthe pleasure and knowledge of every thing in them, shall we be fill'd and satisfied then? And my spirit said 'No, we but level that lift to pass and continue beyond. (11. 1220-1222)

In section forty-seven the poet teaches a message of self-reliance. He becomes the "...teacher of athletics..." (1. 1234) and declares that he who "...by me spreads a wider breast than my own proves the width of his own..." (1. 1235). He suggests that in order to understand him one should go to the "...heights or water-shore..." (1. 1253) for the "...nearest gnat is an explanation..." (1. 1253). Then, after enfolding the diverse mass of out-of-door people in a list (11. 1258-1265) that compares with the brief enumeration set up in section fourteen (11. 255-258) as an introduction to the 
catalogue of occupations, he prepares for the final five sections or the Close of his poem with the all-inclusive line: They and all would resume what I have told them. (1. 1268)

The interpretive analysis of the thought motif of the Prelude indicates a movement from general diversity, progressions one and two, to individualism, progressions three and four. It is evident that the catalogues--diverse life (VIIl-XIII), occupations (XV), identity-sense (XVIII-XXXII)--trace the pattern of the climb from the general to the specific. Then, in progressions five and six, one recognizes an apparent effort to tie the individual in with the masses again. This movement, as reflected in the catalogues of experience and suffering-sympathy, makes the individual akin to and part of the group. Then, in progression seven, the individual is able to speak out to the mass of mankind (XIII-XIVII). The movement of the progression as viewed through the catalogues is from the general lists of diversity and occupations to the specific catalogues of identity and sense and back again to the more general enumerations of experience, sufferingsympathy. In other words, the catalogues of diversity and occupations allow no identity to the individual. He is lost in the general pattern, the mass of mankind. But, in the 'I am' and 'Song of the Senses' catalogues, the individual is 
accorded his identity. However, he loses this identity again in the catalogues of experience, suffering-sympathy, where he merges his own personality with that of his brothers.

A glance at Charts 111 and $1 V$, pages 19-22, shows that a certain balance exists between progressions one and six, two and five, three and four.

Progressions one and six. Progression one is built around a non-experiential catalogue of separate pictures of diverse life in which the poet is only an onlooker while progression six centers around an experiential catalogue in which the poet sufiers and sympathizes with mankind. The points of contrast are: (I) seeing, progression one, and feeling, progression six; (2) stanzaic catalogue forms;

(3) character of non-experience, progression one, and of experience, progression six.

Progressions two and five. In both progressions there is, first of all, a recognition of man's kinship with animal life (11. 249-252, 684-693). Following this recognition the poet moves into the long verse catalogues. The points of balance are seen in: (I) identification with animal life; (2) long verse catalogue forms; (3) identification with the mass of mankind, progression two, and with the Universal, progression five. 
Progressions three and four. Progressions three and four make up the middle ground, the half-way mark, and are presented in a loose quasi-enumerative style which strikes a chord of kinship with the long catalogues of the other progressions. Both climbs stress the individual as the hub of the universe. The 'I am' catalogue of identity, progression three, praises the individual, makes him supreme. However, this same individual is overcome by his emotions in the catalogue of senses, progression four. The two middle progressions tally as to: (I) stress on the individual, on 'I'; (2) loose catalogue forms; (3) man's supremacy, progression three, and man overcome by his emotions, progression four.

In looking back over the pattern of the structural arrangement of the Prelude one cannot help but notice and feel the significance of the important part played therein by the catalogue. Close observation of the charts of progressions on pages $19-23$ reveals that the structural pattern of the Prelude is based upon a systematic balance of catalogue forms. The following chart puts emphasis upon the catalogues by removing them from the charts of progressions. 
CHART VI

A STRUCTURAL OUTLINE OF THE CATALOGUES

\section{PRELUDE}

A. THROWING OUT OF IDEAS:

1. Catalogue of diverse life (VIII-XIII)

2. Catalogue of occupations (XV)

3. Catalogue of identity, 'I am' ( $X X-X X X I I I)$ )

4. Catalogue of senses (XXIV-XXXII)

5. Catalogue of experience ( $X \times X I I I)$

6. Catalogue of suffering-sympathy (XXXIII-XII)

B. DRAWING IN, BHAKING OF RESOLUTIONS:

7. Sermon, words of teacher (XIII-XIVII) 35

The over-all conclusion concerning the Prelude indicates that the progressional climb is based, both in form and thought, upon the catalogues.

35 Refer to footnote twenty-two on page twenty-one of this study. 
The Close (XIVIII-LII)

The Close of the "Song of Myself," the final five sections, is a brief though effective sumary of the main thoughts expressed in the forty-two sections of the Frelude. In this portion of the song Whitman finds he has filled the past and present and must face the future. The prospect of death draws from him a last-will-and-testament tone.

The resolutions arrived at in sections forty-eight and forty-nine are based upon past and present experience and build up to the presentation of the climactic question and explanation in section fifty, while the final words of farewell in sections fifty-one and fifty-two look to the future and move away from the climax. The summarial resolutions of sections forty-eight and forty-nine, based on past and present experience, force the question and explanation in section fifty; the concluding sections, fifty-one and fifty-two, look to the future, the unknown. The movement of the final five sections is from the past and present, the known, sections forty-eight and forty-nine, to the future, the unknown, sections fiftyone and fifty-two. The following chart depicts the movement. 
CHART VII

STRUCTURAL ARRANGENENT OF THE FIVE SECTIONS

OF THE CLOSE

Sections 48-49: Known...Past...Present

Section 50: Present

Sections 51-52: Present...Future...Unknown

The main purpose of the five concluding sections is, like the whole "Song of Myself," a refutation of death. First, in section forty-eight, Whitman reviews all of the main tenets of his philosophy. The lines are in summary address form and are directed toward mankind: (I) The body and soul are equal: body,

I have said that the soul is not more than the And I have said that the body is not more than the soul (11. 1269-70)

(2) Man is a complete and perfect system in the cosmic scheme and is divine:

And nothing, not God, is greater to one than one's self is (1. 1271)

(3) Sympathy is the bond of love and understanding that sustains Iife:

And whoever walks a furlong without sympathy walks to his own funeral drest in his shroud ( 1.1272 ) 
(4) Nature is available to all men:

And I or you pocketzess of a dime may purchase the pick of the earth (1. 1273)

(5) AIl objects are equally perfect and are miracles:

And to glance with an eye or show a bean in its pod confounds the learning of all times (1.1274)

(6) Heroes are found in all occupations:

And there is no trade or employment but the young man following it may become a hero (1. 1275)

(7) Every object contains within itself the secret of its being:

And there is no object so soft but it makes a hub for the wheel'd universe (I. 1276)

Then the poet insists that man "...Be not curious about God..." (1. 1278) and states that no "...array of terins can say how much I am at peace about God and about death" (I. 1280).

Section forty-nine is addressed to death:

And as to you Death, and you bitter hug of mortality, it is idle to try to alarm me.(1. 1209)

and further accentuates the author's refusal to consider death except as a part of Iife. Life becomes only the "...leavings of many deaths..." (I. 1297).

Section fifty moves away from this consideration of Iife and death to an understanding of the divine plan and gives a climactic expression of faith:

It is not chaos or death--it is form, union, plan-it is eternal life--it is Happiness. (1. 1318) 
The two final sections, in descending form, move away from the climax and stray into the unknown, the future. Section fifty serves as a sort of transitional link between the past and the present, sections forty-eight and forty-nine, and the present and future, sections fifty-one and fifty-two. The known part of life, the past and present, is linked up with the future, the unknown part of life, by the simple expression of faith (1. 1318) which does not condone any thought of death or finality.

The past and present (Iife) begin to fade (Sec. LI), and the poet turns to embrace the future (death):

The past and present wilt--I have fill'd them, emptied them,

And proceed to fill my next fold of the future. (11. $1319-1320)$

However, beiore he departs, the poet makes one last effort to secure a final explanation:

Listener up therel what have you to confide to me?

Wiij you speak before $\dot{I}$ an gone? wili you prove already too late? (11. 1321, 1330)

The questions are unanswered, and the poet proceeds, section fifty-two, to an acceptance of what he does not understand. Finally, he recognizes dissolution or a return to the elements as a necessary step toward any future existence and hints at living again in some unsuspected form:

I bequeath myself to the dirt to grow from the grass I Iove,

If you want me again look for me under your bootosoles. 
You will hardly know who I am or what I mean, But I shall be good health to you nevertheless, And filter and fibre your blood. Failing to fetch me at first keep encouraged, Missing me one place search another,

I stop somewhere waiting for you. (II. 1339-1346)

Thus, the concluding five sections of the "Song of Myself" fall into a neat pattern of thought which allows no admission of death. 
Conclusion to Part One

The first step in ascribing a structural design to the "Song of Myself" was a general attempt to put the poet's thoughts in order. However, in fitting his thought pattern into the three divisions suggested by Plato--beginning, middle, end--one found it to be the basis of an inherent structural plan, the three divisions of which--Introduction (I-V), Prelude (VI-XIVII), Close (XIVIII-LII)--were found to be related one to another. That is, the thought threads of the Introduction moved into the Prelude, where they were greatly distended and, from there, into the Close, where they were reduced to sumnary form in specific statements. The Introduction, an effective summary of the contents of the whole poem, charted the course of tine movement and contained, wthin itself, all of the elements of a complete "Song of Myself" in five sections. The Prelude was an enlarged expansion of the Introduction and revealed a step-by step progressional climb, based upon a methodical counterbalance of resolutional and catalogue forms. The Close, in surmary style, pulled together all of the ideas expressed in the Prelude, and reduced them to concise resolutions. Both the Introduction and the Close had certain features in common which tended to effect a balance between them. For instance, as to form, both of these divisions were: (1) comprised of five sections each; (2) presented 
in quasi summary form. And, as to thought, they both reflected a repudiation of degth except as a part of life. The part in between the beginning and end--the middle portion or Prelude--reflected a progressional movement the inherent pattern of which was based upon the systematic balance of catalogue forms. This midale portion used the Introduction as a starting point and the Close as an area of return.

The three divisions of the study were found to be related one to the other. Also, these divisions divulged the author's approach to presenting his thoughts and feeling in an orderly fashion. Thus, the general thesis of Part One, to point up the "Song of Myself" as a work of art, stands substantiated. 
PART 11

THE CATALOGUE 
PART 11

THE CATALOGUE

\section{Introduction}

The catalogue is given its place in the general structural pattern of the "Song of Milself" due to the repeated stress on accumulative lists in the Prelude, Part One. Whitman's tendency to use catalogues, particularly the long ones, has drawn forth much unfayorable criticism. A brief cross-section of such censure follows:

...the usual tedious style of enumeration...the usual auctioneer's catalogue...

...the Whitman catalogues do not fuse into a splendid unity; they remain heterogeneous... they do not persuade emotionally.

...the tangible matter often chokes the imaginative flood; there are too many logs in the stream...3

...Provocatively incomplete...4

The trouble with whitman's agglutinative or catalogue method is not that he makes catalogues, but that the enumerated objects remain inert objects merely. He is often like a yardman coupling parlor-cars whose names are rich in individual associations--Malvolio, Manitoba, Mazzini... But however excitedly these names are ejaculated, this does not start the train...5

1 James Cappon, "The Tradition of Emerson and Whitman in American Literature," Bliss Carman, Louis Carrier and Alan Isles, Inc., New York, 1930, p. 292.

2 Donala Daviason, "Regionalism in American Literature," The American Review, April, 1935, 5:51.

3 Bliss Perry, Walt Witman, Houghton Nifflin Company, New York, 1906, p. 306.

4 Conrad Aiken, Scepticisms, Alfred A. Knopr, New York, 1919, p. 85.

5 Perry, op. cit., p. 306 . 
...lone catalogues are held together by a weak system of monotonous alifteration, or rhythmic similarity. 6

The catalogues! It is easy enough to say that at the end one becomes the I Iunatiq carried at last to the asylum, a confirm'd case'!

...this madness...8

Whitman's catalogues would be even worse than they are had they been written as conscientiously in heroic couplet. 9

Ties up the brain. 10

.... a thousand of brick... 11

... an auctioneer's inventory of a warehouse...12

...this pell-mell of names and things...13

It was so easy...composing as he was...to...stack one brick on top of another, until he had tired himself out. 14

6 Henry Seidel Canby, Walt Whitman, an American, Houghton Mifflin Company, Boston, 1943, p. 323.

7 James Oppenheim, "Whitman," American Writers on American Literature, Horace Liveright, Inc., New York, 1931, p. 260.

8

Ibid.

9 Aiken, op. cit., p. 86.

10 Oppenheim, op. cit., p. 259.

Il Richard Maurice Bucke, Walt Whitman, David McKay, Philadelphia, 1883, p. 143.

12 imory Holloway, Walt Whitman: an Interpretation in Narrative, Alfred A. Knopf, New York, 1926, p. 136.

13 Carleton Noyes, An Approach to Walt Whitman, Houghton Mifflin Company, New York, $1910, \mathrm{p} \cdot 70$.

14 Gay Wilson Allen, American Prosody, American Book Company, New York, 1935, p. 240 . 
...accumulative directory of details...15

...those grotesque Gargantuan enumerations...16

His enumerations... are rank with the odours of flesh.

...the list with its haphazard itens... 18 ...the materials.... are gathered without the
selective principle...

However, this inclination on Whitman's part to use the cumulative list is only his expression of a trend that has moved through a number of pieces of great literature. Some very good illustrations of this trend to catalogue are found in: (I) Homer's Iliad (11:494-876) where the catalogue of ships enumerates both sides of the forces that fought at Troy; (2) all four books of Virgil's Georgics. ('his, the most carefully finished production of Roman literature, 20 is an alnanac-like agricultural catalogue.); (3) the genealogies of the Bible; (4) Francois Rabelais' The Inestimable Life of the Great Gargantua, chapter eight, the catalogue

\footnotetext{
edited by $\frac{\text { The Library of Literary Criticism 1891-1904, }}{6 . \text { Woulton, New York, 1935, 8:151. }}$

16 Cappon, op. cit., p. 272.

17 Ibid.
}

18 Basil De Selincourt, Walt Whitman: a Critical Study, Martin Secker, London, 1914, pp. 146-147.

19 Carl F. Strauch, "The Structure of Walt Whitman's 'Song of Myself, i" English Journal, September, 1938, 27:606.

20 Virgil. H. Rushton Fairclough, translator. George Putnam's Sons, New York, 1932, VoI. 1, p. viii of Introduction. 
of wearing apparel; (5) Edmund Spenser's Faerie queene (Canto I, stanzas VIII-IX), the catalogue of trees; (6) all of the works of Thomas volfe (example: the catalogue of historical events, Look Homeward, Angel, chapter IV); (7)all of the works of Carl Sandburg (example: the catalogue of heroes in the poem, "Good Morning, America," stanza 5). Yet, regardless of the fact that the cumulative list has been used to advantage in the works of other well-known authors, the Whitman catalogue continues to pull down more than its just share of condemnation. Despite the volume of such criticism, however, there has been very little sincere effort to explain the enumerative lists. The question is why the catalogue--the thing the critics bemoan as an apparent weakness--is so prominent in the poem. Perhaps, the answer is that it is the very detail that holds the "Song of Myself" together.

Mattie Swayne, in her study of Whitman's catalogue method, lends emphasis to this idea when she asserts that the catalogue is a permanent and deliberate feature of the poet's art. 21 And, in developing her claim, she recognizes no difference in the catalogue forms other than the degree of elaboration or expansion of the items listed. 22 This

21 Mattie Swayne, "Whitman's Catalogue Rhetoric," University of Texas Studies in English, July, 1941, number 4126, pp. 162-163. 
idea of elaboration is seen as a possible explanation of the two kinds of catalogies we are to study: (I) the simple verse catalogue; (2) the stanzaic catalogue, an amplification of the simple verse unit. I shall attempt demonstrations to point up (I) the stanzaic catalogue as an outgrowth of the simple verse form and, in its turn, (2) the simple list as the basic pattern of the poem. Also, an effort will be made to show that the verse catalogue results from the poet's concentration on words and phrases.

A careful check of the 1346 lines of the "Song of Myself" shows that 879 of them are in various catalogue forms. This figure represents more than three-fifths of the total lines of the poem and, for this reason, helps to emphasize the general thesis that the catalogue may be the basis of the "Song of Myself." However, a breakdown of the 879 lines reveals the following distribution: (1) $328^{\prime}$ lines in regular stanzaic catalogues; (2) 348 lines in quasistanzaic catalogues; ${ }^{23}$ and (3) 203 lines in simple verse forms. The stanzaic forms combine to make a total of 676 lines as against the 203 lines of simple verse. This fact, that the stanzaic lines outnumber the verse forms three to one, helps to accentuate the verse catalogue as the basis for the structural pattern of the stanzaic catalogue.

23 Quasi- stanzaic catalogues are made up of groups of pictures, 100 sely constructed and without any apparent plan at exact enumeration. Their rambling structure is what differentiates them from the more regular stanzaic Iists. Examples are: catalogue of identity (11. 361-496); catalogue of senses (11. 497-709); words of teacher (1I. $1054-$ $-1268)$.. 
The Long Catalogues

In a general overview of the long catalogues one notes an effectual balance. The stanzaic catalogue of diverse life and the verse catalogue of occupations occur in the first part of the song while the verse catalogue of 'ing' experience and the stanzaic catalogue of sufferingsympathy occur in the latter part of the poem. The stanzaic catalogue of diverse life, coming first, is balanced off by the stanzaic catalogue of suffering-sympathy, coming last. In between, the verse catalogue of occupations is balanced off by the verse catalogue of 'ing' experience. The following outline reveals the pattern of balance between the long catalogues of the first and last parts of the poem.

CHART VIII

STRUCTURAL BALANCE BETWEEN THE LONG CATALOGUES OF THE FIRST AND LAST PART OF THE POEM

1. Stanzaic----Diverse Iife (11. 148-241)

2. Verse----Occupations (11. 264-354)

3. Verse-----Experience (11. 717-797)

4. Stanzaic----Suffering-sympathy (11. 806-958, 976-1036)

(There is also a balance between the intermingling of stanzaic and verse forms in lines 242-263 and 1037-1053. These lines represent a mixed-type catalogue.) 
Any introduction to the study of the long catalogues demands, first of all, an exemplification of the difierent types of catalogues. Illustration $A$, which follows, is made up of five verses, and each line draws a separate and distinct picture. These five verses, considered together, make up one verse catalogue or an accumulative list of separate pictures in verse form. Illustration $B$ is made up of five stanzas of two or more verses each, and each stanza presents one single picture. The five stanzas, corisidered as a unit, make up a stanzaic catalogue or, in other words, an accumulative list of separate pictures in stanzaic form. Illustration $\mathrm{C}$ is made up of eleven difierent pictures. The five verses and six stanzas, considered as a whole, make up a mixed versestanzaic unit, an accumulative list of separate pictures in mixed verse-stanza form.

For the purpose of effective demonstration the separate pictures will be numbered according to their respective places in the body of the poem. 
ILIUSTRATION A: VERSE

26.

The pure contralto sings in the organ loft, (1. 264)

27 .

The carpenter dresses his plank, the tongue of his foreplane whistles its wild ascending lisp, (1. 265)

$$
28 .
$$

The married and unmarried children ride home to their Thanksgiving dinner. (1. 266)

$$
29 .
$$

The pilot seizes the king-pin, he heaves down with a strong arm, (1.267)

30.

The mate stands braced in the whale-boat, lance and harpoon are ready, (1. 268)

\section{ILLUSTRATION B: STANZAIC}

\section{0.}

The runaway slave came to my house and stopt outside, pile, I heard his motions crackling the twigs of the woodThrough the swung half-door of the kitchen I saw him limpsy and weak,

And went where he sat on a log and led him in and assured him, And brought water and fill'd a tub for his sweated body and bruis'd feet,

And gave him a room that enter'd from my own, and gave him some coarse clean clothes, And remember perfectly well his revolving eyes and his awkwardness, And remember putting plasters on the galls of his neck and ankles;

He staid with me a week before he was recuperated and pass'd north,

I had him sit next me at table, my fire-lock lean'd in the corner. (11. 189-198) 
11.

The young men float on their backs, their white bellies bulge to the sun, they do not ask who seizes fast to them,

They do not know who puffs and declines with pendant and bending arch,

They do not think whom they souse with spray.

$(12 \cdot 214-216)$

12.

The butcher-boy puts off his killing-clothes, or sharpens his knife at the stall in the market,

I loiter enjoying his repartee and his shuffle and breakdown. (11. 21 7-218)

\section{3.}

Blacksmiths, with grimed and hairy chests environ the anvil,

Each has his main-sledge, they are all out, there is a great heat in the fire.

From the cinder-strew'd threshold I follow their movements,

The lithe sheer of their waists plays even with their massive arms,

overhand the hammers swing, overhand so slow, overhand so sure,

They do not hasten, each man hits in his place.

$$
\text { (11. 219-224) }
$$

14 .

The negro holds firmly the reins of his four horses, the block swags undermeath on its tied-over chain,

The negro that drives the long dray of the stoneyard, steady and tall he stands pois'd on one leg on the string-piece,

His blue shirt exposes his ample neck and breast and loosens over his hip-band,

His glance is calm and commanding, he tosses the slouch of his hat away from his forehead,

The sun falls on his crispy hair and mustache,falls on the black of his polish'd and perfect limbs.

(11. 225-229) 


\section{ILLUSTRATION C: MIXED STANZA-VERSE}

$$
15 .
$$

Oxen that rattle the yoke and chain or halt inthe leafy shade, what is that you express in your eyes?

It seems to me more than all the print I have read in my life. (11. 235-236)

$$
16 .
$$

My tread scares the wood-drake and wood-duck on my distant and day-long ramble,

They rise together, they slowly circle around.

I believe in those wing'd purposes,

And acknowledge red, yellow, whitek playing within me, And consider green and violet and the tufted crown intentional. ( $11.237-241$ )

\section{7.}

And do not call the tortoise unworthy because she is not something else, (1. 242)

$$
18 \text {. }
$$

And the jay in the woods never studied the gamut, yet trills pretty well to me, (1. 243)

\section{9.}

And the look of the bay mare shames silliness out of me. (1. 244)

\section{0.}

The wild gander leads his flock through the cool night,

'Ya-honk' he says, and sounds it down to me like an invitation, close,

The pert may suppose it meaningless, but I listening

Find its purpose and place up there toward the wintry sky. (11. 245-248)

$$
21 \text {. }
$$

The sharp-hoof'd moose of the north, the cat onthe house-sill, the chickadee, the prairie-dog, (1. 249)

22.

The litter of the grunting sow as they tug at her teats, (1. 250) 


\section{3.}

The brood of the turkey-hen and she with her halfspread wings,

I see in them and myself the same old law.

$$
\text { (11. 25i-252) }
$$

\section{4.}

I am enamour'd of growing out-doors,

of men that live among cattle or taste of the ocean or woods,

of the builders and steerers of ships and the wielders of axes and mauls, and the drivers of horses, I can eat and sleep with them week in and week out. (II. 255-258)

\section{5.}

What is commonest, cheapest, nearest, easiest, is Me, Mile going in for my chances, spending for vast returns, Adorning myself to bestow myself on the first that will take me, Not asking the sky to come down to my good will, Scattering it freely forever. (11. 259-263) 
Stanzaic and Verse Catalogues

\section{First study:}

The relationship between the two long catalogues of the first part of the poem--the stanzaic list of diverse Iife (11. 148-24I) and the verse occupational catalogue (II. 264-354)--is to be seen in a pattern of simple expansion of single verses into stanzas of two or more lines each. $A$ close study of illustrations $A$ and $B$ ( $p p$. 65-66), taken from the catalogues of occupations and of diverse life respectively, enables one to see that it would have been comparatively easy for Whitman to have developed each of the five verses of the first illustration into a stanzaic picture of two or more lines and, in this manner, to have made his "Song of Myself" of much greater length. Because the five stanzaic pictures, Illustration $B$, precede the five verse pictures of Illustration $A$ in the body of the poem, the necessary material for a demonstration is at hand. If one takes the pertinent line (underscored) of each stanzaic picture and puts it in its proper place before the five verse pictures, the result becomes a fairly representative Whitman verse catalogue:

The runaway slave came to my house and stopt outside,

The young men float on their backs, their white bellies bulge to the sun,

The butcher-boy puts off his killing-clothes, or sharpens his knife at the stall in the market,

Blacksmiths, with grimed and hairy ohests environ the anvil, 
The negro holds firmly the reins of his four horses, the block swags underneath its tied-over chain,

The pure contralto sings in the organ loft,

The carpenter dresseshis plank, the tongue of his foreplane whistles its high ascending lisp,

The married and unmarried children ride home to their Thanksgiving dinner,

The pilot seizes the king-pin, he heaves down with a strong arm,

The mate stands braced in the whaleboat, lance and harpoon are ready,

These lines help to emphasize a certain relationship between the stanzaic catalogue of diversity (11. 148-241 ) and the verse catalogue of occupations (11. 264-354). It is also possible, in the same manner of the above demonstration, to take relevant lines (underscored) of each of the first nine stanzaic pictures of the catalogue of diverse life:

1.

The little one sleeps in its cradle,

I lift the gauze and look a long time, and silently brush away flies with my hand. (11. 148-149)

2.

The youngster andthe red-faced girl turn aside up the bushy hill,

I peeringly view them from the top. (11. 150-151)

3.

The suicide sprawls on the bloody floor of the bedroom,

I witness the corpse with its dabbled hair, I note where the pistol has fallen. (II. 152-153)

4.

The blab of the pave, tires of carts, sluff of bootsoles, talk of the promenadors,

The heavy omnibus, the driver with his interrogating thumb, the clank of the shod horses on the granite floor,

The snow-sleighs, clinking, shouted jokes, pelts of snow-balls, 
The hurrahs for popular favorites, the fury of rousid mobs,

The flap of the curtain'd litter, a sick man inside borne to the hospital,

The meeting of enemies, the sudden oath, the blows and fall,

The excited crowd, the policeman with his star quickIy working his passage to the centre of the crowd,

The impassive stones that receive and return so many echoes,

What groans of over-fed or half-starv'd who fall sunstruck or in fits,

What exclamations of women taken suddenly who hurry home and give birth to babes,

What living and buried speech is always vibrating here, what howls restrain'd by decorum,

Arrests of criminals, slights, adulterous offers, made, acceptance, rejections with convex lips,

I mind them or the show or resonance of them--I come and I depart. (11. 154-166)

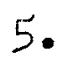

The big doors of the country barn stand open and ready,

The dried grass of the harvest-time loads the slowdrawn wagon,

The clear light plays on the brown gray and green intertinged,

The armfuls are pack'd to the sagging mow.

I am there, I help, I came stretch'd atop of the load,

I felt its soft jolts, one leg reclined on the other, timothy,

I jump from the cross-beams and seize the clover and

And roll head over heels and tangle my hair full of wisps. (11. 167-174)

6.

Alone far in the wilds and mountains I hunt, Wandering amazed at my own lightness and glee, In the late afternoon choosing a safe spot to pass the night,

Kindling a fire and broiling the fresh-kill'd game,

Falling asleep on the gather'd leaves with my dog and my gun by my side. (11. 175-179) 


\section{7.}

The Yankee clipper is under her sky-sails, she cuts the sparkle and scud,

iny eyes settle the land, I bend at her prow or shout joyously from the deck. (11. 180-181)

8.

The boatmen and clam-diggers arose early and stopt for me,

I tuckid my trowser-ends in my boots and went and had a good time,

You should have been with us that day round the chowder-kettle. (11. 182-184)

9.

I saw the marriage of the trapper in the open air in the far west, the bride was a red girl,

Her father and his friends sat near cross-legged and dumbly smoking, they had moccasins to their feet and large thick blankets hanging from their shoulders,

On a bank lounged the trapper, he was drest mostly in skins, his luxuriant beard and curls protected his neck, he held his bride by the hand,

She had long eyelashes, her head was bare, her coarse straight locks descended up on her voluptuous limbs and reach'd to her feet. (11. 195-188)

as well as certain lines from the mixed stanzaic-verse portion, Illustration $\mathrm{C}$ :

\section{5.}

Oxen that rattle the yoke and chain or halt in the leafy shade, what is that you express in your eyes?

It seems to me more than all the print I have read in my life. (11. 235-236)

\section{6.}

Ily tread scares the wood-drake and wood-duck on my distant and day-Iong ramble,

They rise together, they slowly circle around.

I believe in those wing'd purposes,

And acknowledge red, yellow, white, playing within me,

And consider green and violet and the turted crown intentional. (11.237-241) 


\section{7 .}

And do not call the tortoise unworthy because she is not something else, (1. 242)

$$
18 .
$$

And the jay in the woods never studied the gamut, yet trills pretty well to ine, (1. 243)

19.

And the look of the bay mare shames silliness out of me. (1. 244)

20.

The wild gander leads his fllock through the cool night,

'Ya-honk' he says, and sounds it down to me like an invitation,

The pert may suppose it meaningless, but I listening close,

Find its purpose and place up theretoward the wintry sky. (11.245-248)

\section{1.}

The sharp-hoof'd moose of the north, the cat on the house-sill, the chickadee, the prairie-dog, (I. 249)

$$
22 .
$$

The litter of the grunting sow as they tug at her teats, (1. 250)

$$
23 .
$$

The brood of the turkey-hen and she with her halfspread wings,

I see in them and myself the same old law. (11. 251-252)

$$
24 .
$$

I am enamour'd of growing out-doors, of men that live among cattle or taste of the ocean or woods,

Of the builders and steerers of ships and the wielders of axes and mauls, and the drivers of horses,

I can eat and sleep with them week in and week out.

(11. 255-258) 


\section{5 .}

What is commonest, cheapest, nearest, easiest, is We, Tie going in for my chances, spending for vast returns, Adorning myself to bestow myself on the first that will take me, Not asking the sky to come down to my good will, scattering it freely forever. (11. 259-263)

and insert them into their respective places as regards the above representative catalogue (pp. 69-70). Pictures one to nine precede the first five lines and pictures fifteen to twenty-five precede the final five lines of the conjectural catalogue, pages sixty-nine and seventy. The simple demonstration follows:

\footnotetext{
1. The little one sleeps in its cradle,

2. The youngster and the red-faced girl turn aside up the bushy hill,

3. The suicide sprawls on the bloody floor of the bedroom,

4. I mind them or the show or resonance of them, The big doors of the country barn stand open and ready,

6. Alone in the far wilds and mountains I hunt,

7. The Yankee clipper is under her sky-sails, she cuts the sparkle and scud,

8. The boatmen and clamediggers arose early and stopt for me,

9. I saw the marriage of the trapper in the open

10. The runaway slave came to my house and stopt outside,

11. The young men float on their backs, their white bellies bulge to the sun,

12. The butcher-boy puts off his killing-clothes, or sharpens his knife at the stall in the market,

13. Blacksmits, with grimed and hairy chests environ the anvil,

14. The holds firmly the reins of his four horses, the block swags underneath on its tiedover chain,

15. Oxen that rattle the yoke and chain or halt in the leafy shade, what is that you express in jour eyes?
} 
16. My tread scares the wood-drake and the woodduck on my distant and day-long ramble,

17. And do not call the tortoise unworthy because she is not something else,

18. And the jay in the woods never studied the gamut, yet trills pretty well to me,

19. And the look of the bay mare shames silliness out of me,

20. The wild gander leads his flock through the cool night,

21. The sharp-hoof'd moose of the north, the cat on the house-sill, the chickadee, the prairie-dog,

22. The litter of the grunting sow as they tug at her teats,

23. The brood of the turkey-hen and she with her half-spread wings,

24. I am enamour'd of growing out-doors,

25. What is comonest, cheapest, nearest, easiest, is Me.

26. The pure contralto sings in the organ loft,

27. The carpenter dresses his plank, the tongue

of his foreplane whistles its wild ascending lisp,

28. The married and unmarried children ride home to their Thanksgiving dinner,

29. The pilot seizes the king-pin, he heaves down with a strong arm,

30. The mate stands braced in the whale boat, lance and harpoon are ready,

A certain synthesis and kinship between the stanzaic Iist of diverse life and the verse list of occupations is now established, and $i t$ is in order to turn to a consideration of the verse-experiential and the stanzaic-sufferingsympathy catalogues of the latter portion of the poem. 
Second study:

The relationship between the verse catalogue of experience (11. 719-797) and the stanzaic catalogue of suffering-sympathy (11. 806-958, 976-1053) is to be seen in three patterns: (1) change from 'ing' verbal expression (11. 717-796) to direct statement (11.797-1025); (2) change from direct statement (11. 797-1025) back to 'ing' verbal expression (11. 1026-1053); (3) final intermingling of both verse and stanzaic pictures (11. 1037-1053).

\section{(1) Pirst pattern:}

It will be recalled that the subject of the eightyone line experiential list is found in the final line:

I tread day and night such roads. (1. 797) The direct statement, 'I tread,' is a move away from the 'ing' experiential pattern of the foregolng eighty lines. It sets in motion a new statement of activity which is discernible in the catalogue of suffering and sympathy. For demonstrative purposes the following are quoted: (I) the seven concluding lines of the verse-experiential catalogue (11. 791-797); (2) four stanzas from the interpolated plateau found in lines 790-805; (3) seven stanzaic pictures from the catalogue of suffering; (4) four verses from the interpolated plateau found in lines 959-975; (5) seven stanzas from the catalogue of sympathy. 
(1) Speeding through space, speeding through heaven and the stars,

Speeding amid the seven satelites and the broad ring, and the diameter of eighty thousand miles,

Speeding with tail'd meteors, throwing fireballs like the rest,

Carrying the crescent child that carries its own full mother in its belly,

storming, enjoying, planning, loving, cautioning,

Backing and filling, appearing and disappearing,

I tread day and night such roads. (11. 791-797)

(2) I visit the orchards of spheres and look at the product,

And look at quintillions ripen'd and look at quintillions green,

I fly those flights of a fluid and swallowing souI, mets.

Fly course runs below the soundings of plum-

I help myself to material and imnaterial, No guard can shut me off, no law prevent me.

I anchor my ship for a little while only,

Ny messengers continualiy cruise away or bring their returns to me. (11. 798-805)

(3) I go hunting polar furs and the seal, leaping chasms with a pike-pointed staff, clinging

$\frac{\text { to topples of brittle and blue. }}{\text { I ascend to the foretruck, }}$ nest,

I take my plade late at night in the crow's-

We sail the arctic sea, it is plenty light enough,

Through the clear atmosphere I stretch around

on the wonderful beauty,

The enormous masses of ice pass me and I pass

them, the scenery is plain in all directions, The white-topt mountains show in the distance,

I fling out my fancies toward them,

We are approaching some great battle-field

in which we are soon to be engaged, 
We pass the colossal outposts of the encampment, we pass with still feet and caution,

Or we are entering by the suburbs some vast and ruin'd city,

The blocks and fallen architecture more than all the living cities of the globe. (11. 806-816)

I am a free companion, I bivouac by invading watchfires,

I turn the bridegroom out of bed and stay with the bride myself,

I tighten her all night to my thighs and lips.

My volce is the wife's voice, the screech by the rail of the stairs,

They fetch my man's body up dripping and drown'd. (11.817-821)

I understand the large hearts of heroes,

The courage of present times and of all times,

How the skipper saw the crowded and rudderless wreck of the steam-ship, and Death chasing it up and down the storm,

How he knuckled tight and gave not back an inch, and was faithful of days and of nights,

And chalk'd in large letters on a board, 'Be of good cheer, we will not desert you;'

How he followed with them and tack'd with them for three days and would not give it up,

How he saved the drifting company at last,

How the loose-gown'd women look'd when boated from the side of their prepared graves,

How the silent old-faced infants and the lifted sick, and the sharp-lipp'd unshaved men;

All this I swallow, it tastes good, I like it well, it becomes mine,

I am the man, I suffer'd, I was there.

The disdain and calmuess of martyrs,

The mother of old, condemn'd for a witch, burnt wi th dry wood, her children gazing on. (11. 822-834)

$\frac{\text { the am the hounded slave, I wince at the bite of }}{\text { Hell and despair are upon me, crack and again }}$

Hell and despair

I clutch at the rails of the fence, my gore dribs, thinn'd with the ooze of my skin,

I fall on the weeds and stones,

The riders spur their unwilling horses, haul close,

Taunt my dizzy ears and beat me violently over the head with whip-stocks. (11. 838-843) 
Agonies are one of my changes of garments,

I do not ask the wounded person how he feels, I myself become the wounded person,

My hurts turn livid upon me as I lean on a cane and observe. (11. 844-846)

I am the mash'd fireman with breast-bone broken,

Tumbling walls buried me in their debris,

Heat and smoke I inspired, I heard the yelling shouts of my comrades,

I heard the distant click of their picks and shovels,

They have clear'd the beams away, they tenderly lift me forth. (11. 847-851)

I am an old artilierest, I tell of my fort's bombardment,

I an there again. (11. 858-859)

(4) Somehow I have been stunn'd. Stand backl (1. 960)

I remember now, (1.966)

I resume the overstaid fraction, (1.967)

$\frac{\text { I troop forth replenish'd with supreme power, }}{\text { of an average unending procession. (1. 970) }}$

(5) The friendly and flowing savage, who is he?

Is he waiting for civilization or past it and and mastering it?

Is he some Southwesterner rais'd out-doors?

is he Kanadian?

Is he from the Hississippi country? Iowa, Oregon, California?

The mountains? prairie-life, bush-life? or sailor from the sea? him,

Wherever he goes men and women accept and desire

They desire ho should like them, touch thom, speak to them, stay with them.

Behavior lawless as snow-flakes, words simple

as grass, uncomb'd head, laughter, and naivete,

Slow-stepping feet, common features, common modes and emanations,

They descend in new forms from the tips of his fingers,

They are wafted with the odor of his body or breath, they fly out of the glance of his eyes. (11. 976-986) 
Flaunt of the sunshine I need not your bask-lie over!

You light surfaces only, I force surfaces and depths also.

Earthl you seem to look for something at my hands,

Say, old top-knot, what do you want?

Man or woman, I might tell how I like you, but cannot,

And might tell what is in me and what it is

in you, but cannot,

And might tell that pining I have, that pulse

of my nights and days.

Behold, I do not give lectures or a little charity,

When I give I give myseIf. (II. 987-995)

You there, impotent, loose in the knees, open your scarf'd chops till I blow grit within you,

Spread your palms and lift the flaps of your pockets,

I am not to be denied, I compel, I have stores plenty and to spare,

And anytining I have $I$ bestow. to me,

I do not ask who you are, that is not important

You can do nothing and be nothing but I will infold you. (11. 996-1002)

To cotton-field drudge or cleaner of privies I lean,

On his right cheek I put the family kiss,

And in my soul I swear I never will deny him. (11. 1003-1005)

On women fit for conception I start bigger and nimbler babes,

(This day I am jetting the stuff of far more arrogant republics,) (11. 1006-1007)

To anyone dying, thither I speed and twist the knob of the door,

Turn the bed-clothes toward the foot of the bed,

Let the physician and the priest go home. (11. 1008-1010)

I am he bringing help for the sick as they pant on their backs,

And for strong upright men I bring yet more needed help. (11. 1021-1022) 
It has already been noted that the 'ing' pattern of experience changes in the eighty-first line of the list to a direct statement:

I tread day and night such roads. (1. 797) This change in pattern to the direct statement continues on through line 1020 of the stanzaics of suffering and sympathy. However, the thought motif of the lines of experience is not greatly changed, for the pattern of general experience found in the eighty lines of 'ing' activity moves into the stanzaics where it is seen as the actual experience of suffering and sympathy. It is seen that, regardless of the change from 'ing' verbals to direct statements, the thought pattern remains, through line 319, that of general experience and, after line 819, becomes that of individual experience in suffering and sympathy. The following illustration points up this change in pattern by taking the pertinent lines, underscored, from the above-quoted stanzaics and putting them in their appropriate places following the direct statement 'I tread.' The illustration quotes the final seven lines of the long 'ing' experiential list and follows on through with the selected verses of direct statements. (Lines elght to eleven, nineteen to twenty-two, are from the interpolated plateaus found in lines 798-805 and 959-975).

(1) 1. Speeding through space, speeding through heaven and the stars,

2. Speeding amid the seven satellites and the broad ring, and the diameter of eighty thousand miles, 
3. Speeding with tail'd meteors, throwing fire-balls like the rest,

4. Carrying the crescent child that carries its own full mother in its belly,

5. Storming, enjoying, planning, loving, cautioning,

6. Backing and filling, appearing and disappearing,

7. I tread day and night such roads.

(2) 8. I visit the orchard of spheres and $100 k$ at the product, ( 1.798 )

9. I fly those flights of a fluid and swallowing soul, ( 1.800 )

10. I help myself to material and immaterial,

(1. 802)

11. I anchor my ship for a little while only, (1. 804)

(3) 12. I go hunting polar furs and the seal, leaping chasms with a pike-pointed staff, clinging to topples of brittie and blue. (1.806)

13. I arn a free companion, I bivouac by invading watch-fires, (1. 817)

14. I understand the large hearts of heroes,

(1.822)

The disdain and calmness of martyrs,

(1. 838)

15. I am the hounded slave, I wince at the bite of the dogs, (1. 838)

16. I do not ask the wounded person how he feels, I myself become the wounded person, (1. $845^{5}$ )

17. I am the mash'd fireman with breast-bone broken, (1. 847)

18. I am an old artillerest, I tell or my fort's bombardnent, ( 1 . 858)

(4) 19. Somehow I have been stunn'd, Stand back

20. I remember now, (1.960)

21. I resume the overstaid fraction, (1. 967)

22. I troop forth replenish'd with supreme power, one of an average unending procession, (1.970)

(5) 23. The friendly and flowing savage, who is he?

24. Flaunt of the sunshine I need not your bask--Iie overd (1.987)

25. I do not ask who you are, that is not important to me, (1. 1001)

26. To cotton-field drudge or cleaner of privies I lean, (1. 1003) 
27. On women fit for conception I start bigger and nimbler babes, (1. 1006)

28. To anyone dying, thither I speed and twist the knob of the door, (1. 1008)

29. I am he bringing help for the sick as they pant on their backs, (1. 1021)

The twenty-nine lines, taken together, resemble the regular Whitman list although the repeated stress upon 'I' as a line beginning is a novel featore for a catalogue. However, the very emphasis put upon 'I' helps to argue the thesis that the verse catalogue may be the basis for the "Song of Myself." any song about 'myself' would naturally emphasize 'I.' And the change from 'ing' experience to the direct statements of 'I tread,' 'I visit,' 'I fly,' 'I help,' and so on, serves to accentuate 'I' as the chief character of the poem. The direct statements reflect a closer identification with the pain of others, and sympathy ensues.

The above-demonstrated change of pattern from 'ing' verbals to direct statements helps to accentuate a certain relationship between the verse catalogue of experience and the stanzaic list of suffering-sympathy.

(2) Second pattern:

It has been mentioned more than once that the eightyone verse catalogue of experience is built upon 'ing' verbals. It will be recalled that the experience mounts to an expression of high emotion in the final lines of the list (1l. 1-7 in above 1ist). With the direct staternent, 'I tread' (I. 7 above), the rising emotion reaches a climactic plateau 
where it becomes levelled to an expression of identification with the Universal spirit. However, with the statement,"I understand the large hearts..."(1. 14 above), general experience becomes specific experience in suffering. Then, with the statement, "I troop forth..." (I. 22 above), a second plateau and spiritual growth is achieved. Here, the emotional release punctuates an expression of brotherly love and sympathy. Then, following "I am he bringing help..." (1. 29 above), there is an observable move away from the direct statement--which had its inception in 'I tread' ( 1.7 above)-back to the pattern of 'ing' verbals of the catalogue of experience. The concluding twenty-eight lines of the catalogue of sympathy (1I. 1026-1053) are quoted as an illustration of the change in pattern.

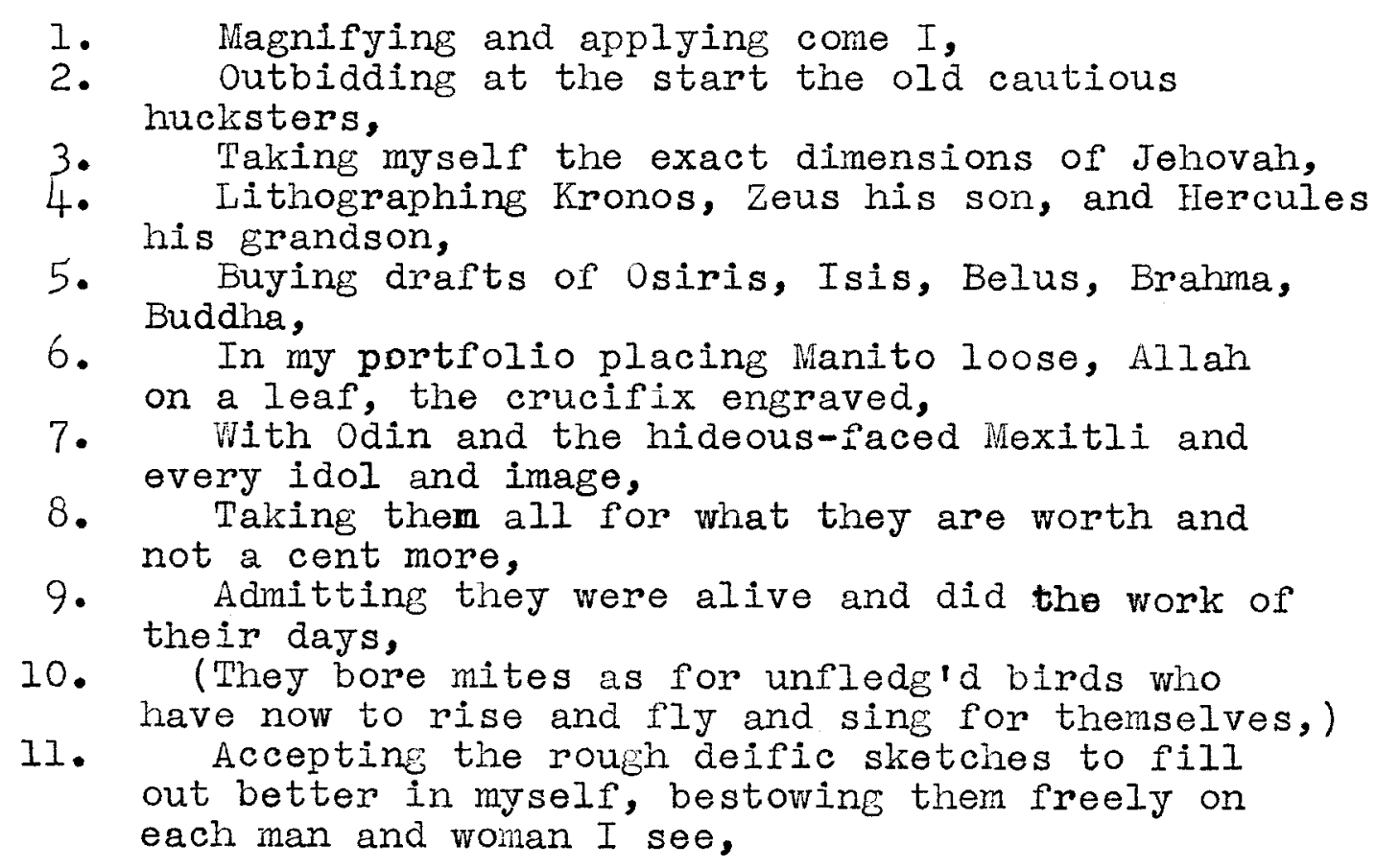
on a leaf, the crucifix engraved,

7. With Odin and the hideous-faced Mexitli and every idol and image,

8. Taking them all for what they are worth and not a cent more,

9. Admitting they were alive and did the work of their days,

10. (They bore mites as for unfledg'd birds who

11. Accepting the rough deific sketches to fill out better in myself, bestowing them freely on each man and woman I see, 
12. Discovering as much or more in a framer framing a house,

13. Putting higher claims for him there with his roll'd-up sleeves driving the mallet and chisel,

14. Not objecting to special revelations, considering a curl of smoke or a hair on the back of my hand just as curious as any revelation,

15. Lads ahold of fire-engines and hook-and-ladder ropes no less to me than the gods of the antique wars,

16. Minding their voices peal through the crash of destruction,

17. Their brawny limbs passing safe over charr'd laths, their white foreheads whole and unhurt out of the flames;

18. By the mechanic's wife with her babe at her nipple interceding for every person born,

19. Three scythes at harvest whizzing in a row fromthree lusty. angels with shirts bagg'd out at their waists,

20. The snag-tooth'd hostler with red hair redeeming sins past and to come,

21. Selling all he pssseses, traveling on foot to fee lawyers for his brother and sit by him while he is tried for forgery;

22. What was strew in the amplest strewing the square rod about me, and not filling the square rod then,

23. The bull and the bug never worshipp'd half enough,

24. Dung and dirt more admirable than was dreamed,

25. The supernatural of no account, myself waiting my time to be one of the supremes,

26. The day getting ready for me when $I$ shall do as much good as the best, and be as prodigious;

27. By my life-lumps! becoming already a creator, 20. Putting myself here and now to the ambush'd womb of the shadows. (11. 1026-1053)

This return to the 'ing' pattern of the eighty line list of experience establishes a point of relationship between the verse-experiential and the stanzaic suffering-sympathy catalogues. The move from the eighty line 'ing' verbal expression of the experiential list to the direct statements of the stanzaic pictures of suffering ( $\mathrm{pp}$. 82-83 of this study) and back again to the 'ing' verbal expression of the final twenty-eight 
Iines of the stanzaic-sympathy catalogue (pp. $84-85$ of this study) effects a harmonious balance and points up the possibility that the entire eighty-one line list of experience and the two hundred and fifty-six lines of stanzaic pictures are related one to the other.

(3) Third pattern:

The demonstrated affinity between the verse and stanza pictures of the latter portion of the "Song of Myself" is augmented still further by the intermingling of both verse and stanzaic pictures in the final seventeen lines of the catalogue of sympathy (11. 1037-1053). The mixed stanzaverse form is illustrated:

Stanza 1. Discovering as much or more in a framer framing a house,

2. Putting higher claims for him there with his roll'd-up sleeves driving the mallet and chisel, (11. 1037-1038)

Verse 3. INot objecting to special revelations, considering a curl of smoke or a hair on the back of my hand just as curious as any revelation, (1. 1039)

Stanza 4. Lads ahold of fire-engines and hook-and-ladder ropes no less to me than the gods of the antique wars,

5. Minding their voices peal through the crash of destruction,

6. Their brawny limbs passing safe over charr'd laths, their white foreheads whole and unhurt out of the flames; (11. 1040-1042)

Verse 7. By the mechanic's wife with her babe at her nipple interceding for every person born, (1. 1043)

Verse 8. Three scythes at harvest whizzing in a row from three lusty angels with shirts bagg'd out at the waists, (1. 1044)

Stanza 9. The snag-toothid hostler with red hair redeeming sins past and to come,

10. Seling all he possesses, traveling on foot to fee lawyers for his brother and sit by him while he is tried for forgery; (11. 1045-1046) 
Stanza 11. What was strewn in the amplest strewing, the square rod about me, and not filling the square rod then,

12. The bull and the bug never worshipp'd half enough,

13. Dung and dirt more admirable than was dream'd,

14. The supernatural of no account, myself waiting my time to be one of the supremes,

15. The day getting ready for me when I shall do

16. as much good as the best, and be as prodigious;

17. Putting myself here and now to the mbush'd womb of the shadows. (11. 1047-1053)

This mixed stanza and verse miscellany helps to point up the relationship between the verse catalogue of experience and the stanzaic catalogue of suffering-sympathy. 


\section{Third study:}

Thus far the demonstrations have pointed up the relationship between: (1) the stanzaic diverse-life list (1.1. 148-241 ) and the verse catalogue of occupations (11. 264-354) of the first part of the poem and (2) the stanzaic suffering and sympathy catalogue (11. 806-958, 976-1036) and verse experiential Iist of the latter part of the poem (11. 717-797). At this point an attempt will be made to show that the catalogues of the first and last parts of the poem are related one to the other and help to make up the main body of the "Song of Miyself." If these catalogues are considered in their condensed forms of simple verse states (pp. 69-70, 74-75, $81-$ -83 of this study) they appear to be held together by an intervening loosely constructed miscellany of a quasi-stanzaic form (11. 33-709). These mixed Iines will be referred to as identity-sense stanzaics. The following chart gives a central or connecting place to them. 
CHART IX

THE PLACE OF THE CATALOGUES OF IDENTITY-SENSE AS RELATED TO THE CATALOGUES OF THE FIRST AND LAST PARTS OF POEM

1. Stanzaic---Diverse Iife (1I. 148-24I)

2. Verse----Occupations (11. 264-354)

3. Quasi-stanzaic----Identity-sense (11. 330-709)

4. Verse----Experience (11. 717-797)

5. Stanzaic----Suffering-sympathy (11. 806-958, 976-1036)

The Iine, "And of these one and all I weave the song of myself $(1.329)$, indicates that the poet plans to sing of himself. Immediately following this assertion of his theme he plunges into a long catalogue of identity (11. 330-547). The loose and rambling structure of this song of 'I,' as well as the song of the senses which overlaps and follows it (11. 497-709), almost convinces one that it is not the basic pattern. And, in the same manner, the constant repetition of 'I' and 'I am' leads one to feel that these words serve as line beginnings for the skeletal framework of the entire passage. (Compare this stress on 'I' with the emphasis put on 'I' and 'I am' as line beginnings in the conjectural catalogue, pages eighty-two and eighty-three of this study.) To 
further credit this theory, one remembers that the poet has promised to"...weave the song of myself..." (1. 329) and, for this reason, would naturally many times refer to 'I' in so doing. The following illustration, a purely conjectural catalogue, is based entirely upon the repetition of 'I' and 'I am.' It is important to notice that: (I) the first two lines are taken from the verse catalogue of occupations and flow naturally into the lines of identity and sense which follow; (2) the first forty-one lines of the passage move easily into the final seven lines which serve as the introduction to the catalogue of 'ing' experience.

1. I am of old and young, of the foolish as much as the wise, (1. 330)

2. I resist any thing better than my own diversity,

3. With music strong I come, with my cornets and my drums, (1. 361)

4. I beat and pound for the dead, (1. 365)

5. Do you guess I have some intricate purpose?

6. Do you take it I would astonish? ( $(1.382)$

7. Why should I pray? why should I venerate and be ceremonious? ( 1.398 )

8. I know I am solid and sound, (I. 403)

9. I know I am deathless, (1. 406)

10. I know I am august, (i. 409)

11. I exist as I am, that is enough, (1. 413)

12. I laugh at what you call dissolution, (1. 419)

13. I am the poet of the Body and I am the poet of the soul, (1. 422)

14. I am the poet of the woman the same as the man, (1. 425)

15. I chant the chant of dilation and pride, (1. 428)

16. I show that size is only development. (1. 430)

17. I am he that walks with the tender and growing night, ( 1 . 433)

18. I too am of one phase and of all phases. (1. 450)

19. I am he attesting sympathy, (1. 46I) 
20. I am not the poet of goodness only, I do not decline to be the poet of wickedness also. (1.463)

21. I find one side a balance and the antipodal side a balance, ( 1.470 )

22. I accept Time absolutely. (1. 480)

23. I accept Reality and dare not question it,

24. I speak the pass-word primeval, I give the sign of democracy, (1. 506)

25. I do not press my fingers across my mouth,

26. I keep as delicate around the bowels as around the head and heart, (1.520)

27. I believe in the flesh and the appetites,

(1. 522)

28. Divine am I inside and out, and I make holy whatever I touch or am touch'd from, (1. 524)

29. I dote on myself, there is that lot of me and all so luscious, ( 1.544$)$

30. I have instant conductors all over me whether I pass or stop, (1.615)

31. I merely stir, press, feel with my fingers, and am happy, (I. 6I7)

32. I am given up by traitors, (1. 637)

33. I talk wildly, I have lost my wits, I and nobody else am the greatest traitor, (1. 638)

34. I went myself first to the headland, my own hands carried me there, (1. 639)

35. I believe the soggy clods shall become lovers and lamps, (1.658)

36. I believe a leaf of grass is no less than the journey-work of the stars, (1.663)

37. I find I incorporate gneiss, coal, long-threaded moss, fruits, grains, esculent roots, (1.670)

38. And am stuccoed wi th quadrupeds and birds all over, (1.671)

39. I think I could turn and live with animals, they're so placid and self-contain'd, (1. 684)

40. I. wonder where they get those tokens, (1. 694)

41. Did I pass that way huge times ago and negligently drop them? (1. 695)

42. Space and Timel now $I$ see it is true, what I guess'd at, (I. 7I0)

43. What I guess'd when I loaf'd on the grass,

44. What I guess'd while I lay alone in my bed,

45. And again as I walked the beach ( 1.712 ) paling stars of the morning. (1. 713)

46. $\mathrm{Hy}$ ties and ballasts leave me, ny elbows rest in sea-gaps, (1. 714) 
47. I skirt sierras, my palms cover continents,

48. I am afoot with my vision. (1.716)

A close study of this conjectural verse catalogue of identity-sense reveals that: (I) it grows out of the closing lines of the catalogue of occupations:

And these tend inward to me, and I tend outward to them,

And such as it is to be of these more or less I am, And of these one and all I weave the song of myself. (11. 327-329)

(2) it moves into the long 'ing' experiential list by way of:

My ties and ballasts leave me, my elbows rest in seargaps,

I skirt sierras, my palms cover continents,

I am afoot with my vision. (11. 714-716)

and, after merging itself with the eighty-one lines of the catalogue of experience, finally (3) moves into the catalogue of suffering and sympathy by means of the spiritual plateau:

I tread day and night such roads. (1. 797)

I visit the orchards of spheres and look at the product, (1. 798)

I fly those flights of a fluid and swallowing soul, (1. 800)

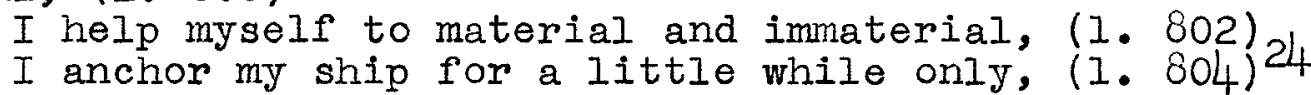

Thus, it is seen that the catalogues of the first part of the "Song of Myself" are linked to the catalogues of the

24 These same five lines are found in lines seven to eleven of the conjectural catalogue on page eighty-two of this study. Notice how easily they flow into the lines of suffering-sympathy there. 
latter part of the poem by means of the intervening lines of identity-sense. With this established relationship of parts, it is easy to see that Whitman has successfully woven the catalogues of the first and last parts of the poem into a certain wholeness of structure by use of the loose threads of his interpolated quasi-stanzaics of identity and sense. 


\section{Verse Catalogue}

The first part of the study demonstrated the stanzaic catalogue to be an expansion or outgrowth of the simple verse catalogue and, in doing so, accentuated the simple verse form as the framework of the "Song of Myself." This division of the study will point up the same idea of expansion in the structure of the verse catalogue as well.

The provocatively incomplete effect of the two long verse catalogues is to stir the reader's imagination. The poet says just enough to stimulate thought and then leaves the rest for the reader. The occupational and experiential lists tally as to line structure, but differ as to thought. The sixty-six line occupational list (11. 264-354) is a simple depiction, in almost unbroken present-tense activity, of what the poet sees while the eighty-one line experiential list (11. 717-797) pictures the poet's mind as actually experiencing what he sees. On the surface the verse catalogue of occupations appears to be a mere recitative of singsong activity and, in some instances, passivity. No alternative or contrasting pattern is apparent in the structure and this fact, in itself, adds to the general monotony. However, the eighty-one line sentence of the experiential list is a move away from the recitative monotony of the sixty-six lines of the occupational list. No longer does the poet 
stand apart and recite his miscellaneous list; he gets into people and lets one know how they feel. And, as a result, a marked degree of emotion is discernible in the concluding lines.

Whitman's almost magical power over the phrase,25together with his concentration on long lists of words and their possibilities, 26 appears to be responsible for this depiction of emotion in the long experiential list. In his An American Primer he claims that a word has a special life of its own and, thus, is imbued with power. He argues that:

A perfect writer would make words sing, dance, kiss, do the male and female act, bear children, weep, bleed, rage, stab, steal, fire cannon, steer ships, sack cities, charge with cavalry or infantry, or do anything that man or woman or the natural powers can do. 27

Sigmund Freud substantiates such a view when he says that, in the beginning, words and magic were one and the same thing. 28

This preoccupation with words and their possibilities finds expression in the long experiential verse list where the pattern of structure is based upon alternate groups of descriptive phrasals and experiential verbals. In order to clarify the structure of the catalogue the following study

25 Perry, op. cit., p. 307.

26 耳amine his An American Primer.

27 Ibid., p. 16.

28 Sigmund Freud, A General Introduction to Psychoanalysis, translated by Jean Riviers, Garden City, New York, 1943, p. 19. 
is presented. The quotations are only partial and are identified by the regular line number of the poem as well as by the line number of the catalogue itself. 
CHART $X$

STRUCTURAL PATTERN OF THE VERSE

CATALOGUE OF EXPERIENCE

CAT.

POEM

LINE

PHRASALS

\begin{tabular}{l} 
NO. SUBJECT \\
\hline 1. \\
2. \\
3. \\
4. \\
5. \\
6. \\
7. \\
9.
\end{tabular}

VERBALS

By the city's...houses

in 108 huts

LINE

camping

10.

weeding

along the ruts

along the dry gulch

hoeing

crossing

trailing

Prospecting

gold-digging

girdling

Scorch'd

hauling

Scaling

pulling

holding

16.

Walking

Where the quail is whistling

Where the panther walks

PUNC. $\frac{\text { NO }}{717}$

hause

where the buck turns

Where the rattlesnake suns

where the otter is feeding

Where the alligator sleeps

Where...the bear is searching

where the beaver pats

Over the...sugar

over the...cotton

over the...rice

Over the...f farm house

Over the...persimmon

over the...corn

over the...flax

13.
14.
15.

Over the... buckwheat

Over the green...rye

719

720

7211

722

723

17 .

Where the bat flies

where...the gold-bug drops

19.

Where...brooks put out

Where cattle stand

Where...cheese-cloth hangs

where andirons straddle

where cobwebs fall

22.

Where trip-hammers crash

where press is whirling 
CATALOGUE OF EXPERIENCE (CONT'D)

CAT.

POEM

LINE SUBJECT

VERBALS

PHRASALS

LINE

NO

23

(floating)

wherever the human heart beats

Where...balloon is floating

NO.

25

(looking)

26.

27.

28.

29.

30 .

31.

32.

approaching

Where the Iife-car is drawn

741

where the heat hatches

Where the she-whale swims

Where the steam-ship trails

Where the fin of the shark cuts

Where the...brig is riding

Where shells grow

where the dead are corrupting

Where the flag is borne

Under N1agara

Upon a door-step

upon the horse-block

35.

36.

enjoying

Upon the race-course

742

743

744

745

746

747

748

749

750

751

At he-festivals

with black-guard gibes

752

37.

tasting sucking

38.

At the cider-mill

753

At apple-peelings

754

wanting

39.

At musters

Where the mocking-bird sounds

Where the hay-rick stands

where the dry stalks are scattered

where the brood cow waits

42.

Where the bull advances

where the stud to the mare

where the cock is treading

Where the heifers browse

where geese nip

Where... shadows lengthen

Where buffalo make

Where the humming-bird shimmers

where the neck... is curving

Where the...gull scoots

where she laughs

Where beehives range

Where...partridges roost

Where burial coaches enter

Where winter wolves bark

Where...heron...comes

Where the splash...cools 
CATALOGUE OF EXPERIENCE (CONT'D)

CAT.

LINE

NO.

SUBJECT

VERBALS

PHRASALS

Where the katy-did works

Through patches

Through the salt-lick

under the conical firs

57.

Through the gymnasium

through the...saloon

58.

Pleas'd

through the office

pleas!d

pleas'd

59.

Pleas'd

Pleas'd

61.

Pleas!d

Pleas'd

impress'd

Looking

flatting

Wandering

Coming

studying

reaching

examining

Voyaging

Hurrying

POEM

LINE

64.

66.

67.

69.

70 .

71.

72.

73.

75 .

Walking

Speeding

76.

77.

78.

79.

speeding

Speeding

Speeding

throwing

Carrying

Storming

enjoying

planning

loving

cautioning

80.

Backing

filling

appearing

81.

disappearing

tread

PUNC. NO.

770

771

772

773

774

775

776

777

778

;

779

780

781

782

783

784

785

786

787

788

789

790

791

792

793

794

795

796

797 
The consideration of the catalogue will be greatly facilitated if we refer to the catalogue line numbers given on the left side of the chart. A general glance at the brief of the catalogue reveals the fact that the first fifty-seven Iines are based upon an alternative pattern of groups of experiential verbals and descriptive phrases. But, beginning with line fifty-eight, the groups of descriptive phrasals are not in evidence. The final twenty-four lines reveal a stress upon experiential verbals and a move away from the descriptive groups. This emphasis on experience and the almost total disregard of description effects the movement of the final Iines and reflects a rising flair of emotion. The pattern of the catalogue alternates between the use of the 'ing' present participle, which reveals the act of mind, and the mixed phrasal groups.

It will be noted that the phrasal groups appear to be drawn for the purpose of (1) pointing the direction or route the poet is to travel and (2) describing what he sees along the way. For example, the prepositions of lines one and two (by, in, along) point the direction the poet is to move while present-tense activity in lines six to nine describes what he sees enroute. In the same manner, the introductory lover' (11. 10-14) points the route of the poet's journey while the present activity of lines seventeen to thirty reveals what he sees along the way. Again, the direction of the journey is pointed out by the use of 'under,' 'upon,' 'at,' 'with,' in 
lines thirty-three to thirty-nine, and wat he sees around him is described in the activity of lines forty through fiftyfour.

The first five lines are devoted in the main to verbals of experience. They are followed, in lines six to fourteen, by two distinct sets of descriptive phrasal groups (11. 6-9 and $10-14)$. Each set is given its separate identity by use of epanaphora and the senicolon. Each verse of the first set (11. 6-9) employs initial repetition in the use of 'Where.' Set one is distinguished from set two by the semicolon line ending (1.9). Set two (11. 10-14) uses initial repetition of lover' and is end-stopped by the sericolon (1. 14).

The verbals of experience in lines fifteen and sixteen are followed in lines seventeen to thirty by one long set of descriptive phrases. While an inserted interpolation of 'ing' activity does occur in line twenty-four, the pattern of the phrasal group, as a whole, is not effected but stands intact. Epanaphora is evident in each verse in the use of the introductory 'Where.' Also, the repetition of 'where' within the lines (11. 18, 21, 22, 25, 30) helps to further unify the passage. The semicolon at the end of line twenty-one marks a slight break between the simple country life (11.17-21) and a more complex life (11. 22-30), but it does not effect the unity of the passage as a whole.

Lines thirtyene to thirty-nine are of a mixed group of verbals and descriptive phrases. The prepositions have the effect of drawing the poet into direct association with the life of the lines. In fact, the line beginnings (Under, 
Upon, At) imply a close contact and the presence of the poet. The entire eighteen verses of lines forty to fiftyseven go into the making of one group of descriptive phrasals. The lines are end-stopped by a semicolon, line fifty-seven. The initial repetition of 'Where' (11. 40-54) and of 'Through' (11. 55-57) puts the vision back upon a broader horizon and is a noticeable move from the limited view of lines thirty-one to thirty-nine. The expansive and detached movement is also helped further by the repetition of 'where' and 'through' within the Iines (11. 41, 42, 43, 46, 47, 57).

This long phrasal group of descriptives is counter$\mathrm{b}$ alanced by the long list of experiential verbals in lines fifty-eight to eighty-one. Whitman, by use of semicolons (11. 62, 65, 69), divides this final twenty-four lines of the catalogue into four separate parts. In the first part (11. 58-62) the use of the past participle''d ending is noted. The initial repetition of 'Pleas'd' furnishes unity and harmony to the five lines. The second division (11.63-65) returns to the old pattern of present 'ing' experience (looking, flatting, wandering). The third portion of the passage (11. 66-69) again reveals the 'ing' experience (coming, studying, reaching, examining). The final division (1. 70-81) stresses an ever-growing experience. The entire twelve verses help to emphasize a growing emotion. The passage calls to mind the metaphoric picture of a ship floating 
in space. And of course, the poet's mind is, in reality, this ship.

This demonstrated alternation of descriptive phrases and experiential verbals as the structural pattern of the catalogue of experience points to Whitman's preoccupation with words and the possibilities of words as the basic pattern of the verse catalogue. 
Conclusion to Part Two

The study of the long verse and stanzaic catalogues revealed a certain existing kinship between the stanzaicdiverse life and verse-occupational catalogues of the first part of the poem as well as between the verse-experiential and the stanzaic-suffering-sympathy catalogues of the latter part of the poem. In the case of the stanzaic and verse catalogues of the firstpart this kinship was found to be due to a simple expansion of single verses into stanzas of two or more lines; in the case of the verse and stanzaic catalogues of the latter part of the poem the relationship was traceable to alternative patterns of expression. The demonstrated relationship of the stanzaic catalogue of diversity to the verse catalogue of occupations and the stanzaic catalogue of suffering-sympathy to the verse catalogue of experience helped to emphasize the possibility that the stanzaic catalogue may be derived from the simple verse form. Next, the lists of the first part of the poem were found to be related to the enumerations of the latter portion of the poem due to the demonstrated mutual kinship of the intervening quasi-stanzaics to catalogues of both groups. And, in considering the stanzaic catalogues of diversity, suffering-sympathy, identity-sense in their condensed forms of simple verse states and placing them in their respective places with 
the occupational and experiential verse lists, we demonstrated an over-all simple verse pattern. This verse motif, together with the demonstrated emergence of stanzaic from verse form, pointed to the simple verse catalogue as the skeletal framework of the "Song of Myself."

An alternating motif of word and phrasal groups was found to be the structural pattern of the verse catalogue of experience. Thus, the third thesis of the study--that the simple verse list may derive from a concentration on words and phrases--was given emphasis.

Part Two, in general, depicted the growth of the poet's thoughts from the simple to the complex. The breakdown of the poem into stanza form, the stanza into verse form, the verse into phrases and words, reflected a pattern which is the law of nature. 29 First, there was the germ or inception in the word. This was followed by slow growth from the simple to the complex and was represented by the expansion of the word into verse form, the verse into stanza form, and the stanza into a whole pattern in the "Song of Miyself."

29 John Burroughs, The Writings of John Burroughs, Houghton Mifflin Company, New York, 1912, 14:5. 
PART 111

VERBAL PROGRESSION 


\section{VERBAL PROGRESSION}

Part Two sets up the verse catalogue as the anatomy of the "Song of Myself" and points to the word as the primary hinge in the skeletal framework. Because Whitman makes the single word basic this study will effect a specific demonstration of the generalization of part two--that the verse catalogue may be a derivative of the single word.

Whitman's poetry, like Emerson's, gives pecedence to thought, rather than form. ${ }^{1}$ However, many of the lines of his "Song of Myself" are made up of a seemingly unrelated thought pattern. Representative of the unrelated pattern are the verse catalogues. Most critics contend that they were created for mere cumulative efrect. ${ }^{2}$ Whatever the purpose behind them, we have the lines to reckon with and cannot help but wonder about their organization.

In the respect that he lays great stress upon the things he sees and hears, Whitman is much like other poets.

1 Norman Henry Pearson, "Literary Forms and Types; or, A Defense of Polonius," English Institute Annual, 1940, Columbia University Press, New York, 1941, p. 69. Ralph Waldo Emerson, "The Poet," Essays, A. I. Burt Company, New York, no date, p. 232.

2 Henry Seidel Canby, Walt Whitma, an American, Houghton Mifflin Company, Boston, 1943, p. 311.

Gay Wilson Allen, American Prosody, American Book Company, New York, 1935, p. 240 . 
However, he appears to have a greater power of memory, both visual and verbal. His taient for visualizing events long past ${ }^{3}$ finds expression in his poetry. But, because memory has a way of collecting rather than joining, many of the cataloguial verses reflect a detached and dissimilar surface. Gay Wilson Allen describes the heterogeneous lines of the long catalogues as an attempt on the part of the poet to "...symbolize the fullness and variety of nature, and to give it 'organic' expression."4' However, it is possible that Whitman meant his catalogues to be more than symbols. Perhaps they are the actual putting to practice of his theory of organic growth and are meant to correspond with the growth of nature. That is, he may have planned for his thoughts to move freely in the catalogues in the same manner that plants grow in nature. Or, in other words, he may have used a word as a hint or provoker 5 to call up new words in the same manner that plants put out new leaves. In fact, he gives us a suggestion that this is his method when he says:

3 James Cappon, "The Tradition of Emerson and Whitman in American Literature," Bliss Carman, Louis Carrier and Alan Isles, Inc., New York, $1930, \mathrm{p} .295$.

4 Gay Wilson Allen, Walt Whitman Handbook, Fackard and Company, Chicago, $1946, \frac{\text { p. } 297 .}{\text {. }}$

5. "A Song for Occupations," The Complete Writings. of Walt Witman, issued under the editorial supervision of his literary executors, Richard Maurice Bucke, Thomas Harned, and Horace Traubel. Vol. 1, p. 265, 11. 130-132. 
From each word, as from a womb, spring babes that shall grow to giants and beget superber breeds...6

However, be this as it may, his style of composition by line, rather than by sentence, does suggest the idea that he thinks his way from one line to another. And the pattern of his thinking appears to be based upon words.

This concern with all kinds of words is revealed in his An American Primer. The habit of compiling long lists of words shows an interest in the content, and not the music, of verbal expression. 7 The primer is a veritable storehouse of verbal evocations. One is led to conclude that fascination with the unlimited possibilities of the smallest unit of speech $^{8}$ is the secret behind the poet's progression in the catalogues. The primer, itself, gives a suggestion of the method:

Names are magic.--One word can pour such a flood through the soul.--Today I will mention Christ's before all other names.--Grand words of names are still left.-What is it that flows through me at the sight of the word Socrates, or Cincinnatus, or Alfred of the olden times--or at the sight of the word Columbus. 9

6 The Uncollected Poetry and Prose of Walt Whitman, collected and edited by Fmory Holloway, in two volumes. Doubleday, Page and Company, Garden City, New York and Toronto,1921, Vol. 2, p. 84.

7 Allen, American,Prosody, p. 219.

8 Walt Whitman, An American Primer, Small, Maynard and Company, Boston, 1904, p. 16.

9 Ibid., p. 18. 
In these, his own words, one has a description of the poet's susceptibility to the suggestive implications of words. He is seen as moving from one class of image to another al ong the paths of association, and his experiences appear to be uncontrolled by the surface intellect. This type of psychosensorial ${ }^{10}$ automatism more than likely had its inception in the poet's belief in a guiding inner light. In any event, his intuitive translation of his supersensual experiences into "...concrete pictorial images. $\therefore$ "ll of reality seems to be automatic.

The French critic, M. Kostyleff, poses a parallel theory of cerebral response and christens it with the name 'verbo-motor' reaction. 12 His idea is that words, like other sensory impressions derived from contact with reality, are stored up in the mind. The storage, in chains of associations, becomes unconscious and soon appears to be forgotten. However, some stimulus automatically sets one word in motion and imnediately the entire chain of associated words is given consciousness again.

It is due to such associational flights of ideas that

10 Evelyn Underhill, "The Mystic as Creative Artist," The Essentials of Mysticism and Other Essays, J. M. Dent and Sons Ltd., London and Toronto, 1920, p. 76 .

11 Ibid.

12 Conrad Aiken, Scepticisms, Alfred A. Knopf, New York, 1919, 9. 35 . 
the lines of unrelated thought matter become successive waves of verbo-motor discharge and move, in every line, farther from the starting point. Whitman's progression from line to line, as well as within the line, appears to be based upon this type of verbo-motor reaction to external stimuli. The confining of the entire rhetorical enerey to words emphasizes the psychology of the author but the least interesting part of it, the accidental.13 For example, i superficial survey of the following lines reveals no immediate relationship between them.

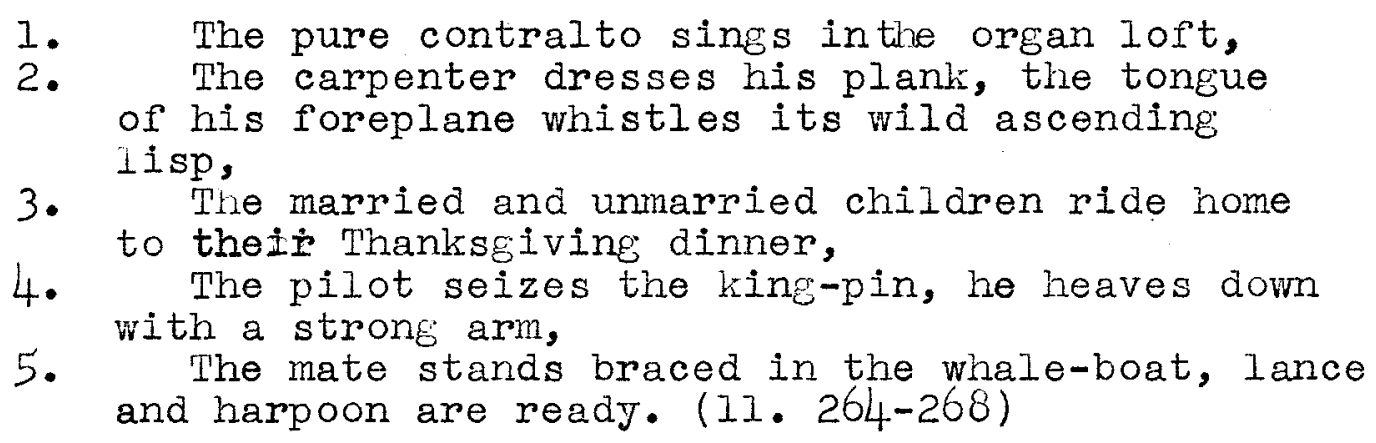
However, despite the seemingly disunited aspect of the 'pure contralto,' the 'carpenter,' the 'children,' the 'pilot,' and the 'mate,' the lines have an inner connection. For instance, the mental image of the 'pure contralto' singing traces the path of a visual and auditory reflex. Both the sight and the sound of the contralto singing are immediately associated with definite verbal reactions. A consideration

\section{Yvor Winters, Primitivism and Decadence, Arrow} editions, New York, 1937, p. 51. 
of the pertinent words of the verse reveals that: (1) 'pure' suggests, phonetically, an unvarying sound made with the oral speech organs in a fixed position and moves, in the second line, to the unvarying 'whistle' of the foreplane; (2) 'contralto' suggests a high male, or low female, voice and moves, in the second line, to the 'whistle' and 'ascending lisp' of the foreplane; (3) 'sings' sugests a certain movement of the tongue and Iips and changes, in line two, to the 'tongue,' 'whistle,' and 'lisp' of the foreplane. In this case the suggestion of 'lips' calls up a fairly good homonym in 'Iisp'; (4) 'organ,' a wind instrument that is made up of sets of pipes which are sounded by compressed air, inspires, in line two, the sounded 'whistle' which results from the passage of compressed air over the 'tongue.' The words--'pure,' 'contralto,' 'sings,' 'organl--ride in on the inward-sweeping stream of consciousness and are met by an outward-moving activity of the brain which recognizes relationships between the words proffered to the senses and other stored-up reflexes. The connecting threads sent out by the four words in line one effect an expression of new images in line two. The 'pure contralto sings' is replaced by the 'tongue,' 'whistle,' and 'lisp' of the foreplane. In a like manner, a consideration of second-line words reveals that they serve as overtones which lead to other changes of figures in lines three and four. For instance, at the mention of the noun, 'plank' (1. 2), 
the poet calls to mind the verb of the same spelling. And the latter form suggests a sort of emphatic slamming down which leads, in line four, to the pilot's seizing the 'kingpin' and heaving down. Also, 'Iisp,' the imperfect pronunciation of 'th' for the sibilants 's' and ' $z$, ' trace the path of a reflex to the imperfect speech of 'children'(1.3) which, in its turn, suggests thoughts of 'home' and 'Thanksgiving' (1. 3). Further concentration on 'Iisp' (1.2) and the 'Th' in 'Thanksgiving' revelals that the tongue is still in the same position as used for whistling in line two. Another connection moves from the insistent repetition of the wild 'lisp' of the foreplane to thoughts of 'din' as a loud noise. And 'din' may be the orertone which calls up 'dinner' (1. 3).

It is possible that the 'Thanksgiving dinner' of line three calls to mind the carving of a turkey, and the position of the carver over the turkey may be the suggestion which cals up the position of the pilot over the 'king-pin' in line four. But, in any event, the position of the carpenter dressing his plank (1.2)sets in motion the position of the pilot over the 'king-pin,' line four, as well as the position of the mate with 'lance and harpoon,' line five. Thus, in the case of these five lines a certain verbo-motor kinship is established. With the above demonstration in mind it is easy to see that words are closely related to certaiin things but, in their far reverberations, they have become associated with 
many objects and ideas. : The chain of associations surrounding each word gives to it many separate and distinct lives of its own. We will accept the theory that verbal reflexes function in associated chains and seek to show that each discharge of reflexes generates and leads directly to another set. No sooner does one trend of ideas come to an end than some suggestion in it inspires and sets in motion another trend of ideas.

In order to point up the thesis that the seemingly unrelated lines of the verse catalogue of the "Song of Iifyself" may be based upon a psychological thought pattern of verbo-motor progression within the lines and from line to line, I offer the two following illustrations. The demonstrations do not presume to show that the poet's mind actually moved along the same paths of associations as are found in the illustrations. But, rather, they are meant to exemplify his method of verbal progression. 


\section{ILLUSTRATION A}

$$
\text { (11. 717-746) }
$$

By the city's quadrangular houses--in log huts, camping wi th lumbermen,

Along the ruts of the turnpike, along the dry gulch and rivulet bed,

Weeding my onion-patch or hoeing rows of carrots

and parsnips, crossing savannas, trailing in forests, prospecting, gold-digging, girding the trees of a new purchase,

Scorch'd ankle-deep by the hot sand, hauling my boat down the shallow river,

Where the panther walks to and fro on a limb overhead, where the buck turns furiously at the hunter, Where the rattlesnake suns his flabby length on a rock, where the otter is feeding on fish, Where the alligator in his tough pimples sleeps by the bayou, Where the black bear is searching for roots or honey, where the beaver pats the mud with his paddle-shaped tail; Over the growing sugar, over the yellow-flowerid cotton plant, over the rice in its low moist field, over the sharp-peak'd farm house, with its scallop'd scum and slender shoots from the gutters, over the western persimmon, over the long-leav'd corn, over the delicate blue-flower flax, over the white and brown buckwheat, a hummer and buzzer there with the rest, over the dusky green of the rye as it ripples and shades in the breeze;

Scaline mountains, pulling myself cautiously up, holding on by low scragged limbs, Walking the path wo in the grass and beat through the leaves of the brush, Where the quail is whistling betwixt the woods and the wheatlot, Where the bat flies in the seventh-month eve, where the great gold-bug drops through the dark,

Where the brook puts out of the roots of the old tree and flows to the meadow,

Where cattle stand and shake away flies with the tremulous shuddering of their hides,

Where the cheese-cloth hangs in the kitchen, where andirons straddle the hearth-slab, where cobwebs fall in festoons from the rafters;

Where trip-hammers crash, where the press is whirling its cylinders,

Wherever the human heart beats with terrible throes under its ribs, 
Where the pear-shaped balloon is floating aloft, (floating in it myself and looking composedly down,) Where the life-car is drawn on the slip-noose, where the heat hatches pale-green eggs in the dented sand, Where the she-whale swims with her calf and never forsakes it,

Where the steam-ship trails hindways its long pennant of smoke,

Where the $\hat{x}$ in of the shark cuts like a black chip out of the water,

Where the half-burn'd brig is riding on unknown currents,

Where shells grow to her slimy deck, where the dead are corrupting below; (11. 717-746) 
CIART XI

VERBAL PROGRESSION: DEPICTING THE FOUR FLIGHTS

OF ASSOCIATIONAI IDEAS FOUND IN

LINLS 717-746

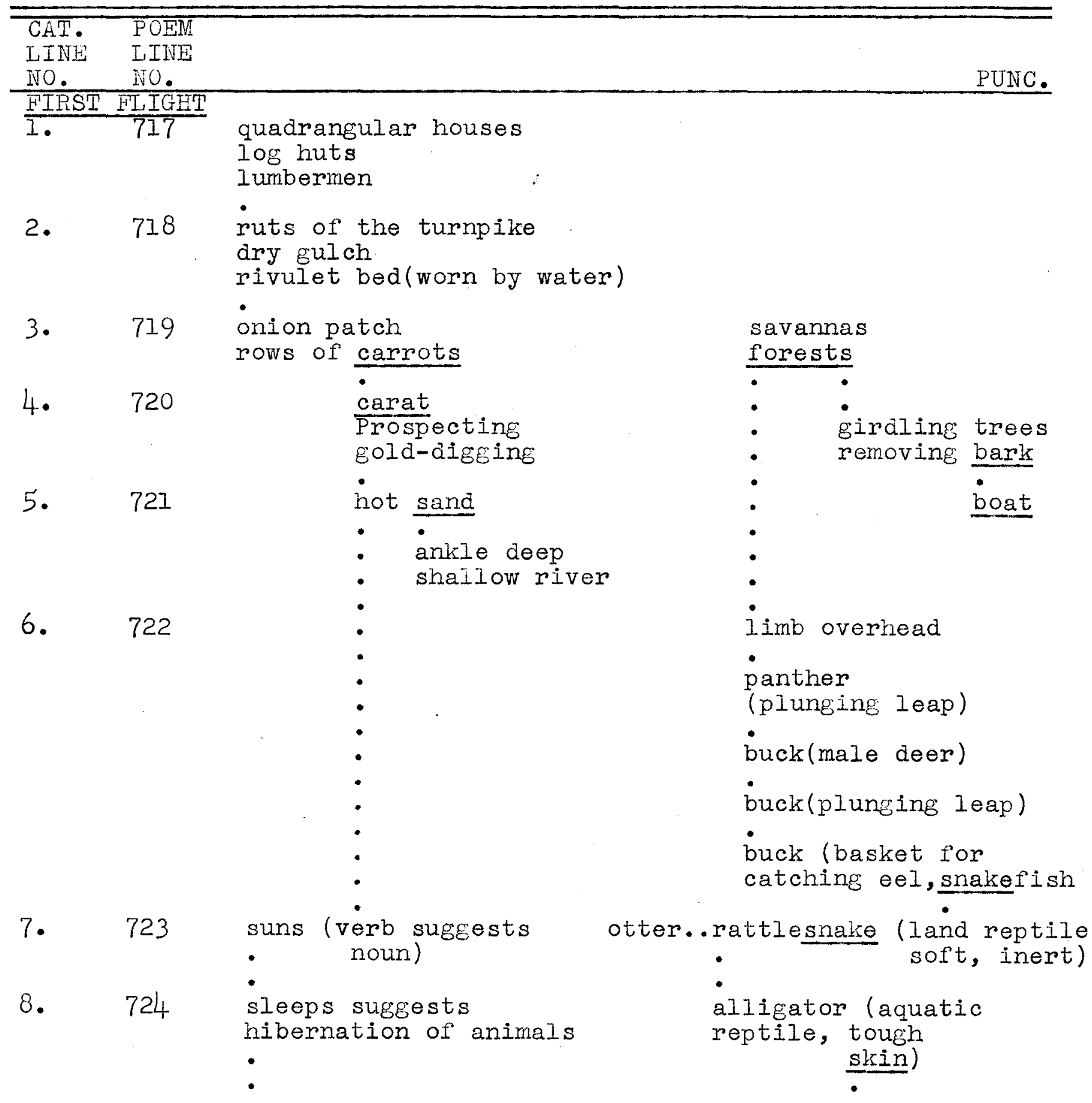


CHART XI

CAT. POEM

(continued)

LINE LINE

NO. HO.

120.

PUINC.

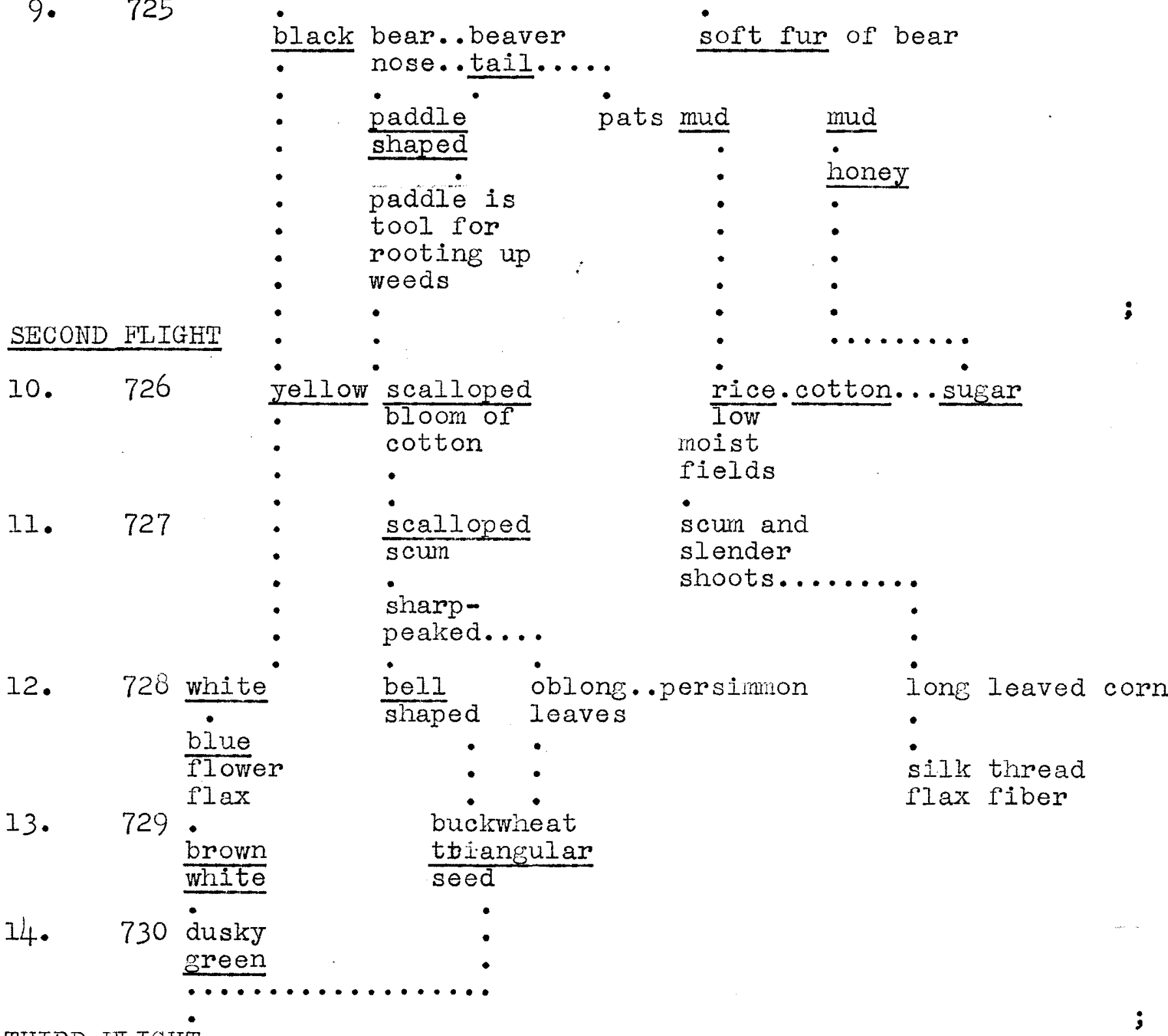

THIRD FIIGHT

15. 731 scale (cover for seed)

scale

scaling..pulling..holding (hand path)..scragged limbs

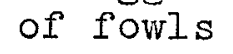
of fowls

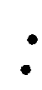


CHART XI

(continued)

\begin{tabular}{lll} 
CAT. & POEN \\
LINE & LINE \\
NO. & NIO. \\
\hline 16. & 732 & $\begin{array}{l}\text { scale } \\
\text { (a ladder) }\end{array}$
\end{tabular}

17. 733

18. 734

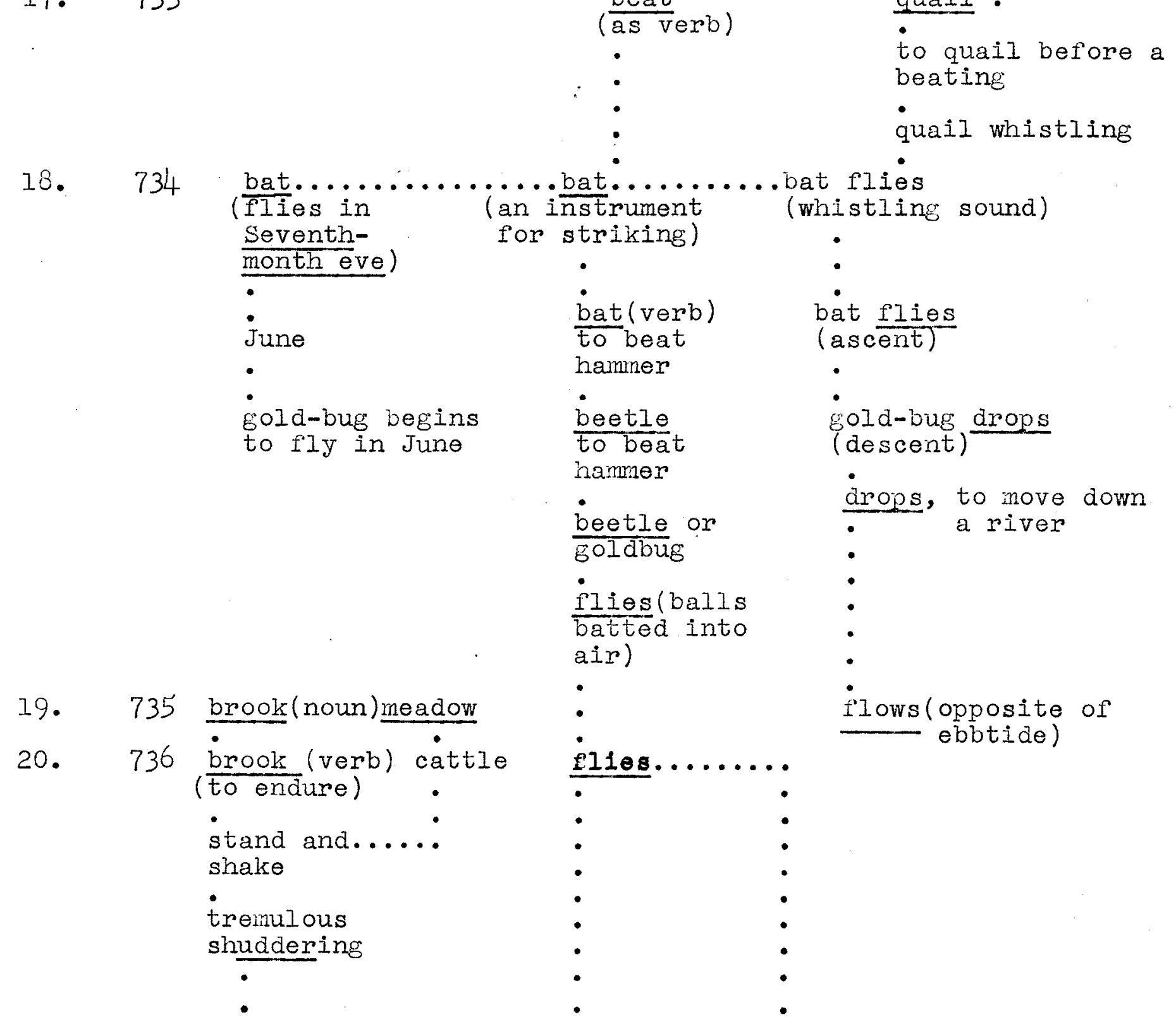

\section{walking ( foot path)}

beat through--rouse game

PUNC. 
GHART XI

CAT. POEM

(continued)

LINE LINE

NO. NO.

\begin{tabular}{|c|c|c|c|}
\hline 21. $\quad 737$ & $\begin{array}{l}\text { cheese } \\
\text { cheesecloth }\end{array}$ & $\begin{array}{l}\text { cheesecloth } \\
\text { (to keep out } \\
\text { flies) }\end{array}$ & $\begin{array}{l}\text { cobweb festoons } \\
\text { (wrought-iron } \\
\text { blooms) }\end{array}$ \\
\hline
\end{tabular}

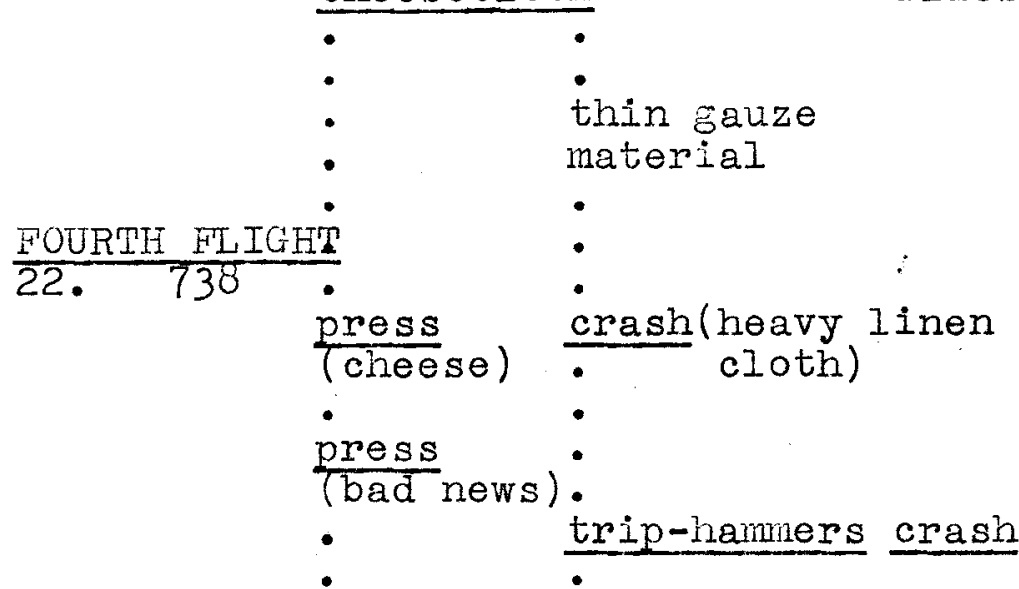

23. 739 throes human heart beats

Tpain

from

heart inflated

hearth-siab(bloomery

where wrought-iron

blooms are made)

bad

news)

agitation

24. 740 calmness

(calmly looking down)

with blood

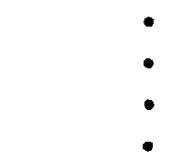

balloon inflated

with gas

balloon (Iife-car

attached by rope)

25. 741 hatches

(verb)

life car of vessel

attached by slipnoose heartshape

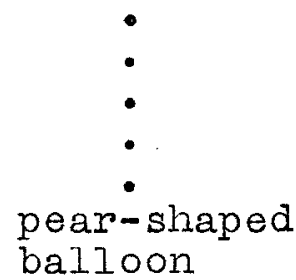

balloon

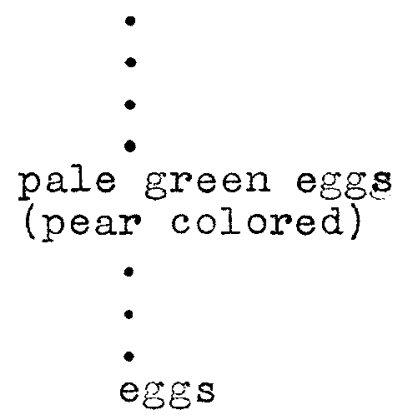

mammal

. (she-whale)

whale cuts water hind-ways (female deer)

27. 743 steamship

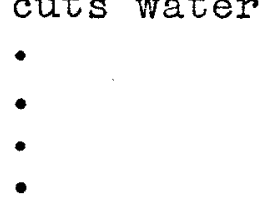


CAT. POEM

(continued)

LINE LINE

NO. NO.

$27 \cdot 74$

peninant or

smoke

-

.

ship

28. 744 black chip shark cuis water

29. 745 half-burn'd brif cuts water

brig

(is a shell)

30. 746

-

shells

shells of pish

slime (mucous secretion of skin of slugs, snails, etc.)

slimy deck

corrupting
PUNC.

stag (male deer) stag (verb) to trail trails 
The thirty lines of the illustration contain four. distinct flights of ideas. Whitman designates the divisional breaks in the thought pattern by the use of semicolons at the close of lines $725,730,737$, and 746 .

The nine lines of Plight one (11. 717-725) depict a setting beyond the frontier. The first line moves away from the 'quadrangular houses' of the city to the 'Iog huts' and 'Iumbermen' of the frontier. 'Log' and 'Iumbermen' suggest a lumber wagon and lumber'wagon, in its turn, the'ruts of the turnpike' (1.2). The dry 'ruts of the turnpike! call to mind the 'dry gulah' and 'rivulet bed' (I. 2) worn by a one-time passage of water. The 'dry gulch' and the 'rivulet bed' are both grooves made by wear and tear of nature. However, they call up their contrast in the manmade irrigated furrows of the 'onion patch' and the 'rows of carrots and parsnips' (1.3).

The cultivation of garden produce, line three, leads to a second association of ideas. For instance, the word 'carrots' (1. 3) is an overtone which starts a new trend of verbal associations. It calls to mind the homonym, 'carat,' the measure for fineness of gold alloy. And, because carrots are the color of gold, there is an immediate nove to 'prospecting' and 'gold-digging' (1.4). A setting is supplied for the prospecting and gold-digging by the 'hot sand,' 'ankle-deep,' and 'shallow river! 
of Iine five. The 'hot sand' (1. 5) suggests the verb 'suns' (1. 7) which, in its turn, is conducive of 'sleeps' (1.8). Line 719, in a similar manner, effects the release of the third set of associations. The cultivated garden is suggestive of a clearing or treeless plain which results in a setting up of opposites in 'savannas' and 'forests' (1. 3). The treeless plains suggest the idea of 'girdling the trees' (1. 4) in order to clear the forests. The stripping off of the bark of the trees suggests a 'bark' or 'boat' (1. 5). 'porests' (1. 3) implies a 'limb overhead' (1.6). The 'panther walks to and fro on a limb overhead' (1.6) is suggestive of a 'plunging leap.' The noun 'buck' calls to mind the verb of the same speliing which means 'plunging leap.' Also, the word 'buck' strikes a third association in the meaning of a basket for catching the snake-like eel. In its turn the snakefish calls up the 'rattlesnake' (1. 7). The inert soft muscles of the land reptile $(1.7)$ call up the contrasting tough pimples of the aquatic reptile, the 'alligator' (1. 8).

The second and third associationsoofideas merge in line nine and bring the first flight tó a close. For instance, 'sleeps' (1. 8) brings the 'prospecting' and 'gold-digging' to an end and suggests the hibernation of animals which leads to the sleep of the 'black bear' (1.9). And, in like manner, the tough skin of the 'alligator' ( 1.8 ) is keyed to a comparison with the soft fur of the lblack bear' (1.9). 
Line nine not only concludes the first flight of ideas but also sets in motion the second flight as well. The overtones which set the pattern for the second flight are found in (I) the contrast between the black bear and the beaver, (2) the contrast between the nose of the bear and the tail of the beaver, and:(3) the words 'honey' and 'mud.' The perfected tail of the beaver calls up the contrasting rudimentary tail of the black bear and suggests a second contrast in the utilitarian value of the nose of the bear as against the 'paddle-shaped' tail of the beaver. Where the bear uses his nose for digging up roots, the beaver pats the mud with his tail. 'Nose' (1.9) is used for foraging roots while 'paddle' (1.9) suggests a tool for rooting up weeds. The sticky consistency of 'honey' calls up a contrast in 'mud' (1.9). Also, the word 'honey' leads to 'sugar' in line ten. 'Mud' (1.9) calls up the 'low moist fields' of line ten. 'Paddle-shaped' (1. 9) carries over into line ten, to the scalloped bloom of the cotton, where it sets in motion a series of shapes which moves through line fourteen.

The second flight starts in line ten with the plants 'sugar,' 'cotton,' 'rice.' An associational chain of shapes, set in motion by 'paddle-shaped' (1. (), moves to the 'yellow flower'd cotton plant' (1. 10). The yellow flower of the cotton plant calls to mind its scalloped shape which, in its turn, 
moves to the 'scalloped scum' (1. 11). The rounded shape of the scalloped edge finds a contrast in the angular shape of the 'sharp-peak'd farm house' (1. 11). The word 'sharp' suggests the sharp taste of the 'westem persimnon' (1. 12) and calls to mind the sharp sound of a bell which results in the image of the bell-shaped flower and oblong leaf of the 'persimmon' (1. 12). The bell-shaped flower calls up the triangular-shaped seed of the 'buckwheat' (1. I3).

Flight two also reveals a second chain of associations in stress on color. The chain has its inception in the word 'black' (1. 9). Emphasis upon color moves from 'black' to 'yellow-flower'd cotton plant' (I. 10), white flower of the 'persimmon' (1. 12), 'blue-flower flax' (1.12), 'white and brown buckwheat' (1. 13), 'dusky green of the rye' (1. 14). A third set of images is called up by the word 'mud' (1. 9). The moverient is from 'pats the mud' (1.9) to the rice in its low moist field' (1. 10), 'the scalloped scum and slender shoots from the gutters' (I. II), the 'longleav'd corn' (1. 12), the 'delicate blue flower flax' (1. 12). For example, the movement is from the beaver patting the mud (1. 9) to the low moist rice fields (1. 10). The slender shoots of rice in the muddy field suggest the 'scum and slender shoots from the gutters' (I. II). The slender shoots move to the 'Iong-leav'd corn' (I. 12), and the silk thread of the corn calls up the silk thread of the flax fiber (1. 12) 
The associational trend of flight three finds its beginning in lines thirteen and fourteen of the second flight. The 'dusky green of the rye' (1. 14) and the seed of the 'buckwheat' (1. 13) call up the idea of a seed covering or scale. 'Scale;'as a ladder or means of ascent, moves to 'scaline mountains, pulling myself cautiously up, holding on' (1. 15). Lines fifteen and sixteen reveal a point of contrast between a hand and a foot path. Line fifteen stresses 'pulling myself up' and 'holding on' while line sixteen puts emphasis upon 'walking the path.' The 'low scragged limbs' (1. 15) suggests the twisting of limbs or the neck of a fowl and moves, in line seventeen, to the bird, 'quail.' The words, 'beat through the leaves of the brush' (1. 16), call up the image of a man beating the brush to rouse game. So the word 'beat' calls to mind thoughts of quailing bef'ore a beating and results in the verb 'quail.' The verb calls up the noun of the same spelling. 'Beat' also sets in motion a new flight of ideas which moves through lines eighteen, nineteen, twenty, and twenty-one. The movernent starts wiith the verb 'beat' which means 'to strike.' This meaning moves to the 'bat,' as an instrument for striking and, thus, to the 'bat' that flies in the 'Seventh-month eve.' This thought chain is subtle in that it suggests the flying ball that is struck by the bat as well as the 'bat: that'flies in the Seventh-month eve.' The 'Seventh-nonth eve' is the month for playing baseball. The word, 'bat,' 
also has other implications. As a verb it means 'to beat,' 'to hammer,' or 'to beetle.' The verb 'beetle' moves to the noun 'beetle' or, in other words, to the 'goldbug' (1. 18). As a verb 'beetle' means'to bat' and sugeests 'flies' or balls batted into the air. The noun, 'flies,' also represents akind of insect and leads, in line twenty, to the cattle and the shaking away of the 'flies.' The insect, 'flies,' calls to mind the old adage of the spider and the fly and results in 'cobwebs' (1. 2l) which, in its turn, calls up the pattern of a web and suggests the wrought-iron blooms or 'cobweb festoons' of line twenty-one. The thought of the wroughtiron blooms calls forth the 'hearth-slab' (1. 2I) or the bloomery where wrought-iron blooms are made. The movement here is based upon a comparison between the architecture of a spider web and of a wrought-iron bloom.

Other associations are between ascent, 'the bat flies' (1. 18), and descent, 'the gold-bug drops' (1. 18). 'Drops' also means to move easily down a river on the ebbtide and is the opposite of 'flows' (1. 19). 'Brook' (1. 19), as a noun, calls up the verb of the same spelline which means 'to endure' and moves, in line twenty, to the patience of the cattle that 'stand and shake.' 'Shake' (1. 20) strikes another chord of association in 'tremulous shuddering' (I. 20). 'Meadow' (1. 19) suggests 'cattle' and, thus, the 'udder' of the cow. The letters 'udder' are removed from the word 'shuddering.' 'Udder,' in its turn, is suggestive of milk 
and leads to thoughts of cheese and 'cheese-cloth.'

The word, 'cheese-cloth' (1.21), is the overtone which carries over into flight four. It serves as the inception of two separate associations of ideas. First, its use in straining cheese is suggestive of the cheese press. The word, 'press,' inspires newspaper 'press' (1. 22) and gives way to the press of bad news, which leads, in line twenty-three, to the 'throes' or agitation caused by bad news. The picture of agitation moves to one of calmness, suggested by the words 'looking calmly down' (1. 24).

The second associational group of flight four moves from 'cheese-cloth' (1.21) as a thin gauze material to 'crash' (1.22) as a heavy linen cloth. Then the noun 'crash' becomes a verb in 'trip-hammers crash' (1. 22). A similarity is seen in the crash of the trip-hammer and the beat of the human heart--itrip-hammers crash' (1. 22) and the 'human heart beats' (1, 23). A contrast is voiced between agitation, 'the human heart beats with terrible throes under its ribs' (1. 23), and serenity, 'floating in it myself and looking composedly down' (1. 24). Another associational thread is evident in the shape of the human heart (1.23) and the 'pear-shaped balloon' (1. 24). The pear green color calls up the 'pale green eggs' (1. 25). 'Eggs' leads to thoughts of a mammal in the 'she-whale' (1. 26). The steam ship'trails hind-ways'(1. 27) leads to 'hind' as a female deer and, from 'hind' to 'stag' as a male deer. The noun 'stag' leads to the verb 'stag' which means to 'trail' and, so, to 'trails' (1. 27). 
A fourth association starts with the verb, 'hatches' (1. 25). The verb calls up the noun and results in the 'hatch' of a vessel. The hatch of a vessel leads to a consideration of the 'steamship' (1.27). The picture of the steamship moving through the water sets in motion both the 'shark' (1.28) and the 'brig' (1.29) cutting the water also. A fifth group of associations starts with 'balloon' (1. 24). The 'balloon' is inflated with gas just as the heart is inflated with blood. The Iifecar of the balioon calls up the 'Iifecar' of the vessel (1. 25) and moves to the steamship and the 'pennant of smoke' (1. 27). Note the play on words--'ship' and 'chip'-in lines twenty-seven and twenty-eight. 'Smoke' puts in motion thoughts of fire and the 'black chip' f(1.28) results. 'Black chip' leads to 'half-burn'd brig' (1. 29) which is, in itself, a 'shell' of a vessel and, so on, to 'shells' (I. 30). 'Shells' calls up the mucous content of shells, in general, and moves to 'slime' or 'slimy deck' (1. 30). 'Slime' leads to the final word, 'corrupting' (1. 30). 


\section{ILLUSTRATION B}

\section{(11. $774-785$ )}

Pleas'd with the native and pleas'd with the foreign, pleasid with the new and old,

Pleas'd with the homely woman as well as the handsome,

Pleas'd wiith the quakeress as she puts off her bonnet and talks melodiously,

Pleas'd with the tune of the choir of the whitewash'd church,

Pleasld with the earnest words of the sweating Methodistpreacher, impress'd seriously at the campmeeting;

Looking in at the shop-windows of Broadway the whole afternoon, flatting the flesh of my nose on the thick plate-glass,

Wandering the same afternoon with my face turn'd up to the clouds, or down a lane or along the beach, liy right and left arms round the sides of two friends, and $I$ in the middle;

Coming home with the silent and dark-cheek'd bushboy, (behind me he rides at the drape of the day,)

Far from the settlements studying the print of animal's feet, or the moccasin print,

By the cot in the hospital reaching lemonade to a feverish patient,

Nigh the coffin'd corpse when all is still, examining with a candle; (11. 774-785) 
CHART XII

VERBAL PROGRESSION: DEPICTING THE THREE FLIGHTS

OF ASSOCIATED IDEAS FOUND IN

LINES 774-785

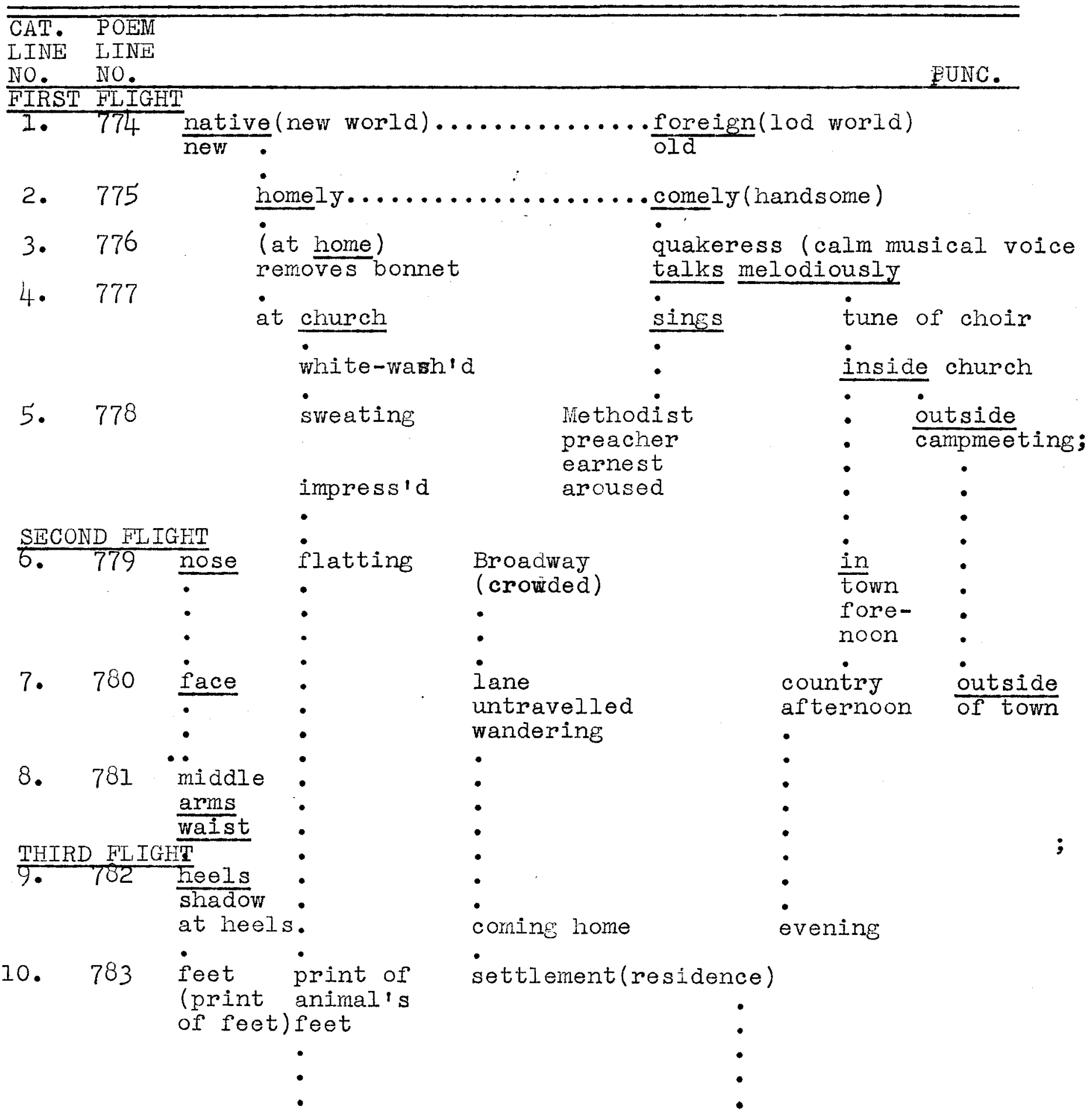


CHART XII

(CONTINUED)

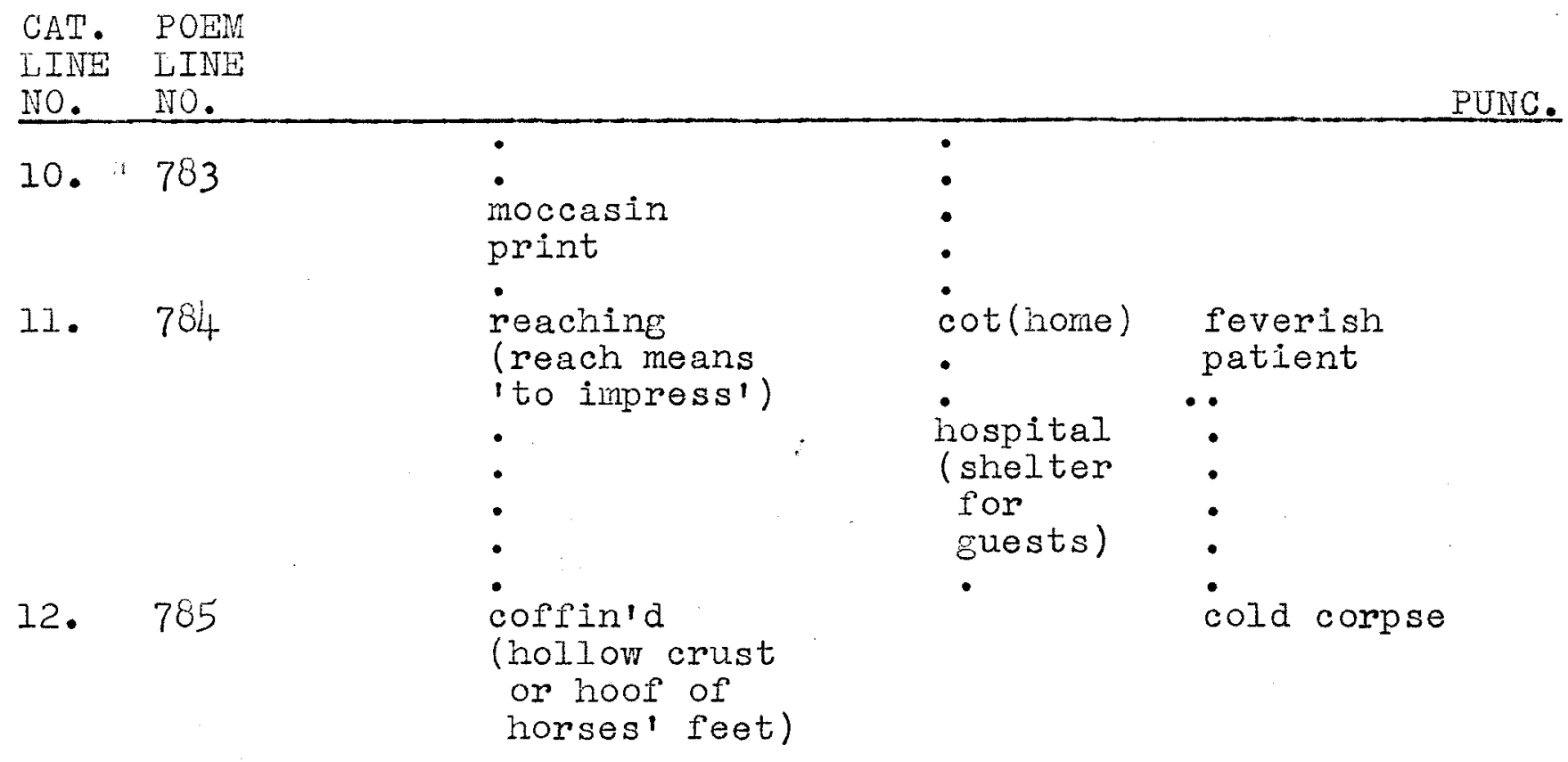


The twelve lines of illustration $B$ contain three flights of ideas. Each separate flight is punctuated and set off from the others by the semicolon line ending. The divisions are marked at the close of lines 778, 781, and 785 .

The movement of flight one is built upon a two-handed theory of progression, the pattern of which is an enumeration of opposites. Repetition helps to emphasize this pattern. 'Native' is balanced off' by its opposite, 'foreign,' and 'new' by 'old' (1. 1). The 'homely woman' calls up the 'handsome' or comely one (1.2). The 'home' scene (1.3) is set off by the 'church' scene (1. 4), the melodious talk of the quakeress (1. 3) by the 'choir' of the church (1. 4), the inside church scene (1. 4) by the campmeeting scene (1. 5), the calm musical voice of the quakeress (1.3) by the earnest and aroused words of the Hethodist preacher (1. 5). The word, 'white-wash'd' (1. 4), calls up the man-made liquid preparation which is used for whitening the skin and moves, from this, to the more natural skin wash, the 'sweating' of the Methodist preacher (1. 5).

The 'white-wash'd church' (1. 4) calls up a contrast in the 'campmeeting' scene (1. 5). The word, 'impress'd' (1. 5), sets in motion a series of associations which moves on through the second and third flights of ideas. 'Impress'd,' as used in line five, means to imprint upon the mind. But the word 
calls up another meaning in the application of pressure to make an impression. With this meaning in mind the movement continues to: the 'flatting' of the nose against the plate glass windows (1. 6); the 'print' of animals' feet (1. 10); 'moccasin print' (1. 10); 'reaching' in the sense that it means to impress (1. 11); 'coffin'd,' in the sense that it calls to mind the hollow crust or hoof of the foot of a horse and the impression it makes on the soil (1. 12). The outside camp-meeting' scene (1. 5) and the inside church scene (1. 4) of the first flight of associations gives place, in the second flight, to the outside-of-town scene (1. 7) and the in-town scene (1.6). The morning town scene (1. 6) sugkests the afternoon country scene (1. 7). In this second fight stress is put upon parts of the body. It starts with 'nose' (1.6) and moves to 'face' (1. 7), 'arms' (1. 8), 'middle' or waist (1. 8), 'heels'-shadow at heels-- (1.9).

The afternoon scene, flight two, gives place in flight three, to the evening and night scenes. 'Wandering' (1. 7) moves to thoughts of 'coming home' (1.9). The word 'home' inthe sense that it means a place of residence, calls up 'settlement' (1. 10) which, in its turn, suggests 'cot' another word for home (1. 11). Also, 'cot' calls up 'hospital' 
(1. II) as a place for sheltering travellers. The third flight is brought to an end by power of suggestion, a move from life to death, in the consideration of the 'feverish patient' of line eleven and its opposite, the cold 'corpse' of line twelve.

Idiustrations $A$ and $B$ help to point up the poet's method of progression from line to line and within the line in his long verse catalogues. In both charts the demonstrated associational flights of ideas have their inception in a single word. Whitman's preoccupation with the unlimited possibilities of words is given free rein and finds a climax in the composition of the long verse catalogues. 


\section{CONCLUSION}


CONCLUSION

The original purpose of this study was to reveal the central plan or form of the "Song of Myself." The three divisions of the thesis helped to point up this plan. First of all, Part One gave the structural arrangement of the poem in the light of Plato's definitive requirements that a work of art must have a beginning, middle, end, as well as a certain synthesis of parts, and. it placed the catalogue in the structural plan of the whole. Part Two contained two demonstrations: the first stressed the emergence of the stanzaic catalogue from the verse catalogue and, thus, pointed to the simple verse catalogue as the skeletal framework of the "Song of Myself"; the second broke down the verse catalogue into its component parts of phrases and words and projected the idea of the single word as the unit of thought in the verse catalogue. Part Three put stress on words as the psychological framework of the long verse catalogues.

The breakdown of the poem, as demonstrated in the three parts of the study, moved from the consideration of the whole "Song of Myself" to the stanzaic catalogues and, from there, to the simple verse list and the single word. Thus,it is seen that the three divisions of the study point up a balanced structural design for the long "Song of Myself." 
BIBLIOGRAPHY 
A. BOOKS

Aiken, Conrad, Scepticisms. New York: Alfred A. Knop 1919.

Alexander, S., Space, Time and Deity, Vol. 2. Iondon: Macmilian and Company, 1920.

Allen, Gay Wilson, American Prosody. New York: American Book Company, 1935.

Allen, Gay Wilson, Walt Whitman Handbook, Chicago: Packard and Company, 1946.

Austin, Mary, The American Rhythm. New York: Houghton Mifflino company, I930.

Bailey, John, Walt Whitman. New York: The Macmillan Company, 1926.

Bucke, Richard Maurice, Walt Whitman. Philadelphia: David McKay, 1883.

Burroughs, John, The Writings of John Burroughs, Vol. 14 . New York: Houghton Jifrin Company, 1912.

Canby, Henry Seidel, Classic Americans. New York: Harcourt, Brace and Company, 1931.

Canby, Henry Seidel, Walt Whitman, an American. Boston: Houghton Mifflin Company, 1943.

Complete Writings of Walt Whitman, The, in ten volumes. Issued under the editorial supervision of his literary executors, Richard iliaurice Eucke, Thomas B. Harned, and Horace L. Traubel. With bibliographical and critical material prepared by Oscar Triges. New York: and London: G. P. Putnam's Sons, 1902.

De selincourt, Basil, Walt Whitman: a Critical Study. London: Martin Secker, 1914 .

Dialogues of Plato, The, Vol. 1. Translated into English by B. Jowett with an introdiction by Raphael Demos. New

York: Random House, Inc., 1937. In two volumes.

Fairchild, H. N., An Approach to Literature. New York: Prentice-Hall, Inc., 1929. 
Freud, Sigmund, A General Introduction to Psychoanalysis. English translation by Jean Riviers. Garden City, New York: Garden City Publishing Company, Inc., 1943.

Gray, George B., The Forms of Hebrew Poetry. New York: Hodder and Stoughton, 1915.

Hazlitt, Henry, The Anatomy of Criticism. New York: Simon and Schuster, 1933.

Hindu Scriptures. Edited by Nicol Macnicol. New York: E. P. Dutton and Company, Inc., 1943.

Holloway, Hmory, Writman: an Interpretation in Narrative. New York: Alfred A. Knopf, 1926.

Jevons, F. R., Comparative Religion. New York: G. P. Putnam's Sons, 1913.

Jones, Llewellyn, How to Criticize Books. Nwe York:

W. W. Norton and Company, Inc., 1928.

Ker, W. P., Form and Style in Poetry. London: liacmillan and Company, Limited, 1928.

Library of Literary Criticism 1891-1904. Charles W. Moulton, editor. New York: 1935, Vol. 8.

Modern Reader's Bible, The. Edited by $\mathbb{R}$. G. Moulton. New York: The liacmilian Company, 1925.

Noyes, Carleton, An Approach to Walt Whitman. New York: Houghton Miffin Company, 1910.

Patterson, William M., The Rhythms of Prose. New York: Columbia University Press, 1916.

Perry, Bliss, A Study of Poetry. New York: Houghton Mifflin Company, 1920.

Perry, Bliss, Walt Whitman. New York: Houghton Mifflin Company, 1906 .

Saidla, Leo E. A., Essays for the Study of Structure and Style. New York: The Kacmillan Company, 1939.

Sheldon, H. Horton, Space, Time and Relativity. New York: The University Society, inc., 1932. 
Virgil. English translation by H. Rushton Fairclough. New York: George Putnam's Sons, 1932, Vol. 1 .

Walt Whitman. Edited with an introduction, bibliography, and notes by Floyd Stovall. New York: American Book Company, 1934 .

Warren, Samuel, The Lily and the Bee. Edinburgh and London: William Blackwood and Sons, 1851.

Whitman, Walt, An American Primer. Horace Traubel, editor. Boston: Small, Maynard and Company, 1904 .

Whitman, Walt, Leaves of Grass (facsimile edition of 1855 text). Portland, Maine: Thomas Bird Mosher, 1919.

Walt Whitman's Workshop. Edited with an introduction and notes by Clifton Joseph Furness. Cambridge: Harvard University Press, 1928.

Winter, Yvor, Primitivism and Decadence. New York: Arrow Editions, $\overline{1937 .}$

The Uncollected Poetry and Prose of Walt Whitman, in two volumes. Collected and edited by Emory Holloway. New York and Toronto: Doubleday, Page and Company, 1921.

\section{B. PERIODICAL ARTICLES}

Babbit, Irving, "Buddha and the occident," The American Review, 7:66-97, April, 1936.

Blodgett, Harold, "Whitman and Buchanan," American Literature, 2:131-140, no date.

Blodgett, Harold, "Whitman and Dowden," American Literature, 1:171-182, May, 1929.

Bracley, Sculley, "The Fundamental Metrical Principle in Whitman's Poetry," American Literature, 10:437-459, January, 1939.

Campbell, Killis, "The Evolution of Whitman as an Artist," American Iiterature, 6:254-263, November, 1934 .

Carpenter, Frederic, "Immortality from India," American Literature, 1:233-242, November, 1929.

Davidson, Donald, "Regionalism in American Literature," The American Review, 5:48-61, April, 1935. 
Holloway, Emory, "Walt Whitman's Love Affairs," Dial, 69:473-483, November, 1920.

Howard, Leon, "For a Critique of Whitman's Transcendentalism," Modern Language Notes, 47:79-85, February, 1932.

Hungerford, Edward, "Walt Whitman and his Chart of Bumps," American Literature, 2:350-384, January, 1931.

Lowell, Amy, "The Rhythms of Free Verse," Dial, 64:51-56, January, 1918.

Lowell, Amy, "Walt Whitman and the New Foetry," Yale Review, 16:502-519, April, 1927.

More, Paul Elmer, "The Modernism of French Poetry," The American Review, 5:329-348; Summer, 1935 .

Myers, Henry, "Whitman's Conception of the Spiritual Democracy," American Literature, 6:239-253, November, 1934.

Myers, Henry, "Whitman's Consistency," American Literature, $8: 243-257$, November, 1936.

Remenyi, Joseph, "Walt Whitman in Hungarian Literature," American Literature, 16:181-185, November, 1944.

Ross, R. C., "Whitman'sVerse," Modern Language Notes, 45:363-364, June, 1930.

Scott, Fred Newton, "The Most Fundamental Differentia of Poetry and Prose," Publications of the Modern Ianguage Association, 19:250-269, 1904.

Strauch, Carl F., "The Structure of Walt Whitman's 'Song of Myself'," English Journal, 27:597-607, September, 1938.

Swayne, Mattie, "Whitman's Catalogue Rhetoric," University of Texas Studies in English, number 4126, pp. 162-178, July, 1941 .

Whitman, Walt, "The Poetry of the Future," North American Review, 132:195-210, 1881.

Wiley, Autrey Nell, "Reiterative Devices in Leaves of Grass," American Literature, $1: 161-170$, May, 1929. 


\section{ESSAYS}

Bucke, Richard Maurice, "Walt Whitman," Cosmic Consciousness. New York: E. P. Dutton and Company, Inc., 1901. Pp. 215-236.

Cappon, James, "The Tradition of Emerson and Whitman in American Literature," Bliss Carnan. New York: Louis Carrier and Alan Isles, Inc., 1930. Pp. 257-312.

Cappon, James, "New Systems of Verse: Whitman and Paul Claudel," Bliss Carman. New York: LouisCarrier and Alan Isles, Inc., 1930. Pp. 313-333.

Dun, Waldo H., "Song of Nyself," Encyclopedia Americana, 1945 edition. 25:255-256. :

Ellis, Havelock, "The Artist in Words," What is a Book?, Dale Warren, editor. New York: Houghton Mifflin Company, 1935. Pp. 63-75.

Ellis, Havelock, "Whitman," The New Spirit. New York: Houghton Mifflin Company, 1892. Pp. 89-132.

Emerson, Ralph Waldo, "The Poet," Essays. New York: A. I. Burt Company, no date, pp. 227-253.

Foerster, Norman, "Whitman," American Criticism. New York: Houghton Mifflin Company, 1928. Pp. 157-222.

Mill, John Stuart, "Thoughts on Poetry and its Varieties," Dissertations and Discussions. New York: Henry Holt and Company, 1874. Vol. 1, pp. 89-120.

Oppenheim, James, "Whitman," American Writers on American Literature. John Macy, editor. New York: Horace Liveright, Inc., 1931. Pp. 258-273.

Pearson, Norman Henry, "Literary Forms and Types; or, A Defense of Polonius," English Institute Annual, 1940. New York: Columbia Uni versity Press, 1941. Pp. 61-72.

Sandbure, Carl, Introduction to Poems by Walt Whitman. New York: Boni and Liveright, 1921. Pp. iii-xi. 
Stevenson, Robert Louis, "Walt Whitman," Essays, Formal and Informal. Frank Scott, editor. New York: Richard R. Smith, inc., 1930. Pp. 220-246.

Stovall, Floyd, "Whitman," American Idealism. Norman, Oklahoma: University of Oklahoma Press, 1943. Pp. 79-96.

Underhill, Evelyn, "The Mystic as Creative Artist," The Essentials of Hysticism and Other Essays. London and Toronto: J. M. Dent and Sons Ltd. and New York: E. F. Lutton anà Company, 1920. Pp.64-85. 